\title{
CEsifo WORKING

The Direct and Indirect Effect of Services Offshoring on Local Labour Market Outcomes

Martina Magli 


\section{Impressum:}

CESifo Working Papers

ISSN 2364-1428 (electronic version)

Publisher and distributor: Munich Society for the Promotion of Economic Research - CESifo

$\mathrm{GmbH}$

The international platform of Ludwigs-Maximilians University's Center for Economic Studies and the ifo Institute

Poschingerstr. 5, 81679 Munich, Germany

Telephone +49 (0)89 2180-2740, Telefax+49 (0)89 2180-17845, email office@cesifo.de

Editor: Clemens Fuest

https://www.cesifo.org/en/wp

An electronic version of the paper may be downloaded

- from the SSRN website: www.SSRN.com

- from the RePEc website: $\quad$ www.RePEc.org

- from the CESifo website: https://www.cesifo.org/en/wp 


\title{
The Direct and Indirect Effect of Services Offshoring on Local Labour Market Outcomes
}

\begin{abstract}
I prove new empirical evidence on the direct and indirect impact of services offshoring on local labour markets outcomes. Differently from the rest of the literature, I account for the effects that offshoring of services has on firms that are not directly involved in offshoring, but that are located in the same local labour market from where offshoring originates. I employ a unique detailed dataset on firms in the UK for the period 2000-2015 and exploits geographical differences in services trade flows across the country. Services offshoring is measured using precise information on firms' location and trade in services flows. The analysis proceeds first estimating the causal average impact of services offshoring on local labour markets, showing positive elasticity of employment and wages. On a second step, it exploits firms' heterogeneity and shows that part of the increase in average employment and wages is driven by the spillover effects of services offshoring on the firms non involved in services trade directly. Further, services offshoring widens the dispersion of firms, also when accounting for changes in the composition of firms through time and firms' trade status. Finally, I look at the heterogeneous impact of services offshoring based on workers' characteristics, showing higher elasticities of employment and wages to services offshoring of workers in managerial and professional occupation or with a higher level of education.
\end{abstract}

JEL-Codes: F100, F160, J200.

Keywords: services offshoring, local labour market, spillover effect, quantile analysis.

\author{
Martina Magli \\ LMU Munich / Germany \\ Ludwigstr. 28 \\ martina.magli@econ.lmu.de
}

I am grateful to my $\mathrm{PhD}$ advisors Holger Breinlich, Konstantinos Tatsiramos and Richard Upward for their suggestions and support. I also thank Andrea Ariu, Daniel Baumgarten, Luca Braghieri, Carsten Eckel, Sarah Eichmeyer, Lisandra Flach, Michael Koch, Luca Macedoni, Kalina Manova, Lionel Roger, Alessandro Ruggeri, Anirudh Shingal, Gregory Veramendi and Yoto Yotov for their valuable comments. I am equally thankful to all the seminar participants where I presented the paper. All errors are mine. This work contains statistical data from the Office for National Statistics supplied by the UK Dataservice. The use of these data does not imply the endorsement of the ONS or the UK Data Service at the UK Data Archive in relation to the interpretation or analysis of the data. This work uses research datasets which may not exactly reproduce National Statistics aggregates. 


\section{Introduction}

Services offshoring, defined as the imports of intangible inputs from abroad, is increasingly relevant on the global scale. ${ }^{1}$ While an extensive literature examines the impacts that the offshoring of manufacturing goods production has on the domestic labour force, much less attention has been paid to the effects of services offshoring (see Hummels et al. (2018) for an extended review). Likewise, the thriving literature on the impact of trade on local labour markets focusses on the direct effect of trade on employment and wages, and frequently disregards any spillover mechanisms on these measures (see Autor et al. (2016) for a comprehensive review of the current literature). Understanding the effects of services offshoring on local labour markets, taking into account both the direct and the spillover mechanisms, can shed new lights on the ongoing discussion on the overall gains from trade. When firms (both manufacturing and services) hire consultants from abroad, have a foreign subsidiary to program their software, or move their call-centre to a country where labour is cheaper, how will this affect wages and levels of employment of the importing firms and of their competitors at home? This paper aims to answer these questions and estimates both the direct and indirect impact of services offshoring in the labour market from where offshoring originates.

This paper employs a highly disaggregated firm-level dataset from the UK and explores the variation of services offshoring across labour markets coming from the different geographical distribution of firms' plant. I use three different empirical methodologies (OLS fixed effects, shift-share instrument and recent development in quantile analysis) to uncover new empirical facts on the effects of services offshoring on employment and wages. I show that indeed services offshoring increases employment and wages within local labour markets and that a substantial part of the positive results is driven by spillover effects. Non-offshoring firms increase their employment and average wages due to the offshoring of services of the firms located in the same local labour market, a new findings in the offshoring literature. At the same time, as the increases in employment and wages are unevenly distributed across firms, services offshoring in essence increases firms' dispersion within local labour markets. The implications of the paper are twofold. First, I highlight the importance of both direct and indirect effects of services offshoring, which might be valid for economies other than the UK. The economic mechanisms I explore in the paper are a novelty also for the manufacturing offshoring literature and emphasise the relevance of general equilibrium adjustments in offshoring studies. Second, since 2001 the share of trade agreements including chapters on trade in services has increased, rising the importance of trade in services for trade negotiations. The findings of this paper are therefore extremely informative to policymakers shaping new trade policies.

\footnotetext{
${ }^{1}$ Using information included in the WIOD, services offshoring across all sectors has increased constantly in the period 2000-2014, with an average yearly rise of $8 \%$ and an overall increase of $22 \%$ between 2000 and 2014 . In the same period manufacturing offshoring has increased $5 \%$ yearly and $12 \%$ between 2000 and 2014 .
} 
From a macroeconomic perspective most countries, including those specialised in labour-intensive sectors as China and India ${ }^{2}$, have experienced a significant increase in services as share of GDP as well as an increase in the volume of trade in services over the course of the last three decades. Moreover, new technologies and the globalisation of the markets have opened new possibilities to increase services offshoring (Baldwin, 2016, 2019). At the micro level, many firms that are traditionally located in the manufacturing industry are deriving an increasing share of their revenues from services (Breinlich et al., 2018; Ariu et al., 2019a, 2020; Bernard et al., 2017; Blanchard et al., 2017; Crozet and Milet, 2017b; Lodefalk, 2013). Further, trade in goods and trade in services behave differently in practice (Ariu, 2016), and their role in the production process is by nature dissimilar (Melvin, 1989).

However, how services offshoring affect the labour markets depend on several channels that may work into opposite directions. As argued by Egger et al. (2015), not all firms may engage in services offshoring equally, and, especially if offshoring costs are high, more productive firms are more likely to do so than less productive ones. In this case only the most productive firms reallocate jobs abroad, reducing employment and shifting it towards the less productive firms, which will still have their services carried out domestically. On the opposite, if trade costs are lower, a larger share of firms can engage in offshoring and workers reallocated towards high productive firms as well. Further and similarly to Autor et al. (2013), increase in services offshoring might lead firms to become smaller or exit in the labour markets most exposed to the services import competition.

On the other hand, productivity will increase for the firms that engage in offshoring, which again can bring about improvements of labour market outcomes (Grossman and Rossi-Hansberg, 2008; Egger et al., 2015). The improvements might not be restricted to the firms directly involved in offshoring, but propagated to the non-offshoring firms through supply chain linkages or spillover similarly to the general equilibrium model as in Adão et al. (2019a) . Depending on the distribution of firms and on the level of offshoring costs, the positive effects from productivity gains may outweigh the negative effects of offshoring, leading to improved domestic labour market outcomes. Which of the suggested channels prevail is a priori unclear, and determining the overall effects of services offshoring eventually remains an empirical question.

Using data from the UK's Office of National Statistics (ONS), I construct a unique firm-level dataset on firms in Great Britain ${ }^{3}$ including information on trade in services, on firms' activities and geographical location for the period 2000-2015. The final dataset has both a panel dimension (for firms with more than 249 employees and some smaller) and a repeated cross-sectional one (all other firms), features that are used separately in the paper. I show that around $17 \%$ of British firms are involved in trade in services, belonging to all sectors of the economy and scattered throughout the country.

\footnotetext{
${ }^{2}$ See Neely et al. (2011); Vandermerwe and Rada (1988).

${ }^{3}$ Great Britain includes the territories of England, Wales and Scotland, but, as opposed to the United Kingdom, excludes Northern Ireland. Country-level statistics in international databases are typically reported for the UK, and for simplicity I will sometimes refer to these statistics to describe general trends.
} 
Trade in services includes computer services, telecommunication, professional services, $R \& D$ and it is mainly of intermediates of production. The data employed are ideal to evaluate the effects of services offshoring not only for its unique nature, but also due to the role that Great Britain has on a global scale: second only to the US in terms of trade in services.

At first, I seek to establish a causal relation between services offshoring and local labour markets outcomes, using the latter as unit of analysis. Local labour markets are defined as sector local areas from where the offshoring has originated, taking into account recent studies showing that workers tend to be static both in their sector of employment (Dauth et al., 2017; Curuk and Vannoorenberghe, 2017), as well as in their geographical area (Adão et al., 2019a; Caliendo et al., 2019). Using firm population weights, I measure services offshoring as the aggregate of imports of services from abroad of all firms located in a local labour market. The empirical strategy then exploits the variation across time of services offshoring on local labour markets employment and wages, including a wide range of fixed effects. A Bartik-style instrumental variable (IV) strategy addresses the potential endogeneity of services offshoring, using as an instrument the sector variation of imports of intermediate services from a selected pool of exporting countries ${ }^{4}$ to a selected pool of importing countries. ${ }^{5}$ The instrument captures the increased comparative advantage in the services industry of selected exporting countries due to new technologies and recent international trade agreements. Indeed, the instrument takes into account the most recent criticisms to shift-share and Bartik instruments (as in Adão et al. (2019b); Borusyak et al. (ming); Goldsmith-Pinkham et al. (2020); Jaeger et al. (2018)) and includes a wide set of fixed effects and time varying control variables that correct for any potential bias. Results from OLS and IV analysis show that services offshoring increases local labour markets employment and wages, implying that within a local labour market, positive reallocation and spillover effects exceed negative import substitution and competition effects.

Afterwards, the analysis exploits firms heterogeneity and explicitly concerns with distributional aspects of services offshoring, employing recent developments in quantile analysis (Chetverikov et al. (2016)). This exercise shows that offshoring of services has different effects along with firms' employment and wage distributions, benefiting the most larger firms and those paying higher wages. Further conditioning the distribution of firms on their composition and their offshoring status, the results suggest that services offshoring leads to an increase in size inequality between firms within a local labour market.

On a second step, the paper aims to explore the channels through which offshoring of services affects positively average labour market outcomes. Exploiting the panel dimension of the data, I first show that offshoring of services increases employment and average wages of both offshoring and nonoffshoring firms, a finding that suggests the importance of spillover effects within local labour markets.

\footnotetext{
${ }^{4}$ France, Germany, the US, Ireland and the Netherlands.

${ }^{5}$ Australia, Canada, Japan and South Korea.
} 
These indirect effects include supply chain linkages, imitation by non-offshoring firms of best practices carried out by offshoring firms, changes in market competition due to services offshoring and import competition effects. Similarly to Hummels et al. (2014), I distinguish between broad and narrow offshoring. Broad offshoring is defined as the overall imports of intermediate services, while narrow offshoring the trade in services restricted to those services competing with firms' main output. The two different measures allow to distinguish between the effects from the imports of intermediates inputs (broad offshoring) and of inputs that are part of firms' portfolio (narrow offshoring). I am therefore able to discern the import competition effect from the other effects. For non-importing firms, narrow offshoring reduces employment and wages, a result in line with the findings of the import-competition literature. ${ }^{6}$ On the other hand, the offshoring of services not competing with firms' main output increases the labour market outcomes, further highlighting positive indirect effects (e.g. supply chain linkages, changes in competition and imitation spillover).

Positive effects of services offshoring might be driven by certain categories of workers, as in Ariu et al. (2019b) and Criscuolo and Garicano $(2010)^{7}$, as well, services offshoring might have spillover effect on those workers employed in non-offshoring firms. The empirical analysis hence proceeds estimating the effects of services offshoring on the labour markets by workers' characteristics. I find that workers with high education or in professional occupations are those benefiting the most in terms of higher employment and wages, by the exposure to services offshoring. As in the quantile analysis, results suggest an increase in the differences between workers both in employment levels and hourly pay due to services offshoring.

Throughout the paper the analysis focuses on the sector-local area level. At last, I compare the effects of services offshoring using different definitions of local labour markets employed in the literature: local areas (as geographical area), sectors and sectors-local areas. I show that offshoring of services decreases local employment and average wages with sectors specifications, opposite to the effects at sector-local area and local area level. This latest result highlights how different definitions of local labour market account not only for different variations of offshoring (e.g. changes across time within sectors versus within geographical areas), but also for different general equilibrium adjustments (e.g. sector definition does not take into account reallocation between sectors). A result that is particularly relevant and might apply to the rest of the local labour market literature.

This study contributes to the literature in several ways. First, decomposing the analysis between offshoring and non-offshoring firms suggests that a sizeable share of the beneficial labour market effects accrue via firms that do not themselves engage in services offshoring. At the best of my knowledge

\footnotetext{
${ }^{6}$ See Autor et al. (2016).

${ }^{7}$ Differently from the present work both papers look at the direct impact of services offshoring. Ariu et al. (2019b) look at the direct impact that services offshoring has on employment and wages of offshoring firms in Finland. Criscuolo and Garicano (2010) estimate the effects that higher opportunities to trade in service have on the wages of different occupations.
} 
this paper is the first one showing the importance of the spillover effect of offshoring on non-offshoring firms. ${ }^{8}$

Differently from the rest of the literature on services offshoring, I look at the economic dynamics at local labour markets level. The unit of analysis represents a novelty as earlier studies typically consider either larger administrative or geographical units (Amiti and Wei, 2005a,b; Crinò, 2008; Gheishecker and Görg, 2011; Amiti and Wei, 2009b,a), or individual firms (Ariu et al., 2019b; Girma and Görg, 2004; Hijzen et al., 2011; Eppinger, 2019; Liu and Trefler, 2019). Compared to aggregate and industrylevel studies, the detailed firm-level data I use make it possible to obtain more accurate measures of services offshoring. In particular, I have to make no assumptions about the homogeneity of firms within sectors, as I have information on the imports of each firm, which I aggregate to obtain precise measures of services offshoring for each sector local area. At the firm level, offshoring is distinguished between narrow and broad, accounting for each firms' production process. Hence I am able to discern the different channels through which offshoring affects firms. In the temporal dimension, the analysis covers the period from 2000 to 2015, which, to the best of my knowledge, is the longest and (except for Ariu et al., 2019b; Eppinger, 2019) most recent sample considered in the literature.

Further, this paper builds a bridge between the literature on trade in services and the burgeoning literature on the local labour market effects of trade. This literature, which focusses on import competition (typically from China) in the manufacturing industry, has usually found labour market outcomes to deteriorate with increasing trade exposure (examples include Autor et al., 2013, Autor et al., 2014, Acemoglu et al., 2016 for labour markets in the US, Balsvik et al., 2015 for Norway, Malgouyres, 2016 for France, Keller and Utar, 2016; Utar, 2018 for Denmark). ${ }^{9}$ In this context, the present study is most closely related to Wang et al. (2018), as their focus is also on imports of intermediate inputs rather than final products, as well as on spillover effects . Besides focussing on the manufacturing rather than on the services sector, Wang et al. (2018) examine a different type of spillover: While they identify gains that occur upstream and downstream the value chain, I measure indirect effects of trade on firms within the same sector local area. Therefore, while Wang et al. (2018) highlight the "cascade" effects of trade, I shed a light on the implications of trade on firms' competitors.

Finally, the present paper adds on the most recent literature on services trade using UK data: these include Ottaviano et al. (2018), looking at the impact of immigration on UK trade in services;

\footnotetext{
${ }^{8}$ I refer to Hummels et al. (2018) for a complete overview.

${ }^{9}$ In a similar vein, Dauth et al. (2014) show that increased import competition from Eastern Europe resulted in lower manufacturing wages in Germany. Consistent with the other studies, the highest losses in terms of cumulative earnings are experienced by workers formerly employed in import-oriented manufacturing industries (Dauth et al., 2021). At the same time, lower employment due to "the rise from Eastern competition" are more than offset by the rise in exports opportunities in Germany from Eastern Europe (Dauth et al., 2014). Similarly for Spain, rises in employment in the construction sector counteract the decrease in manufacturing employment due to the increased imports from China (Donoso et al., 2015).
} 
Costa et al. (2019), which looks at the impact of intermediate trade of services on workers' wages and training in the UK and Javorcik et al. (2020), which estimates the impact of Brexit on labour supply in the UK. Indeed, the research question of the present work differs from Ottaviano et al. (2018), Costa et al. (2019) and Javorcik et al. (2020) as it further explores the spillover mechanisms and distributional impacts of services offshoring on employment and wages. In terms of data, the present work is different from Costa et al. (2019) and Javorcik et al. (2020) as it merges firms' information with trade in services data, exploiting the geographical dimension it and allowing to control for firms' heterogeneity. Compared to Ottaviano et al. (2018), the present study uses an additional firm-level dataset $^{10}$ which allows to extend the analysis to the period 2000-2015.

The remainder of the paper is organised as follows. The next section describes the employed datasets and presents some stylized facts on trade in services. Section 3 presents the identification strategy and the results at the average level. Section 4 includes the identification strategy and results of the quantile analysis while section 5 presents the analysis distinguishing between offshoring and nonoffshoring firms. Section 6 provides an overview of the results for different groups of workers, and section 7 estimates the impact of the offshoring of services using different definition of local labour markets. Finally, section 8 discusses the results and concludes.

\section{Data and Stylized facts}

I combine three set of data from the UK Office of National Statistics (ONS) to obtain information on trade in services flows and firms in Great Britain for the period 2000-2015. In the specific, for firm-level data on trade in services I employ the International Trade in Services Survey (ITIS), which contains information on the country of origin/destination and the type of service traded. The dataset is then merged with the Annual Respondent Database (ARD) and the Annual Business Survey (ABS), the official sources of information on firms in UK used to construct national statistics. I refer to section $\mathrm{B}$ in appendix for a detailed description of the datasets and of the methodology used to merge the information. As a brief summary, the final dataset is an unbalanced panel containing information on firms (including geographical location) and trade in services activities. The characteristics of the datasets are such that for all observation information on geographical location, employment, turnover and sector are available. Additional information on firms characteristics and economic activities (e.g. expenditure in Computer Services, R\&D activities, value added etc.) are available for all large firms (in a panel structure) and for a sample of small firms (in a cross section and repeated cross section structure). ${ }^{11}$

Based on the information contained in the ITIS, in 2012 intra-firms services are the most traded

\footnotetext{
${ }^{10}$ Full description of the datasets employed are included in section 2 and appendix B

${ }^{11}$ The dataset contains firms population weights, employed in the analysis. The use of population weights clear the potential sampling issues of small firms moving in and out of the surveyed sample.
} 
services by UK firms, accounting for almost $20 \%$ of all imports and $17 \%$ of all exports (figure A.1). ${ }^{12}$ Amongst the other most imported services, computer services (e.g. software) account for $9 \%$ of imports, royalties and licences (e.g. franchise, trademark licensing) for 8\%, and telecommunication (e.g. call management services) for 7\%. Financial services (e.g. financial asset management) are the most exported product (if excluding intra - firms services), accounting for $12 \%$ of the total. ${ }^{13}$ Among the most exported services follow computer services (7,48\%), and engineering (e.g. design, development and utilization of machines), which account for $5,47 \%$ of the total.

Heterogeneities on the type of services traded exist and depend on the sector a firm belongs to (table A.1). Firms in manufacturing with low and medium technological intensity, for example, are mainly importing professional services, representing $1.34 \%$ of the total imports of professional services in 2012. In general terms, ICT and professional services are amongst the top three most imported and exported services for all sectors with only few exceptions. Taken together, manufacturing sectors account for almost $10 \%$ of the overall exports of professional services (e.g. consultancy, engineering, management) in 2012. Therefore, non-service sectors are at the same time importing services as intermediates of production, as well as exporting other services. This implies that firms that are not themselves located in the services industry are producing services as well, consistent with the literature on the "servitisation" of economies and of the manufacturing sector in particular (Bernard et al., 2017; Breinlich et al., 2018; Crozet and Milet, 2017a).

Looking at trade partners, the US is the largest one and accounts for $23.73 \%$ and $22.27 \%$ of total imports and exports (see figure A.2). For the trade partners listed in figure A.2, in table A.2 I show the three most traded services with the UK. The percentage in parenthesis shows the share of the country- service trade flows on the total trade flows of that services in the UK. As an example, the second most imported service from the US in the UK is royalties and licensing, which accounts for $19,49 \%$ of total imports in royalties and licensing in the UK. As for the exports, R\&D is the third most exported service (15.69\% of UK total exports in R\&D) after financial services (12.60\% of UK total exports in financial services).

As expected, high volumes of services are exchanged with EU members, together accounting for a third of all imports and a quarter of all exports in 2012. Amongst those, the main partners are Germany and Ireland, accounting for about $10 \%$ of total imports and exports of computer services. Other relevant countries for British imports of services are Japan (3.63\% of the total), Switzerland $(2.88 \%)$, India $(2.88 \%)$ and China (less than $1 \%$ of the total).

\footnotetext{
${ }^{12}$ According to the definition used in the survey, intra-firm services are trade flows across borders within the same company, therefore a non-specified composite of services that firms declare to be trading with their affiliates. Because of their blurred definition, intra-firms services flows are excluded to compute the offshoring measures in the main analysis. Appendix D presents the results when measuring services offshoring as the aggregate of intra-firms services.

${ }^{13}$ Exports of financial services in figure 1(b) are lower than the overall export picture of the UK as the data available to researchers exclude the trade in financial and insurance services of banks and of some financial institutions.
} 
The composition of countries is different when looking at the top ten export partners: Switzerland is the second most important destination of UK exports (6.23\% of the total in 2012) and other important trading partners include Saudi Arabia (3.56\% of total) and the Channel Islands (2.09\%). The last two countries are the destination of around $5 \%$ of total exports on financial services, $3.19 \%$ of legal services (Channel Islands) and $25.95 \%$ of other transactions (Saudi Arabia), a composite of unspecified services.

As for firms' behaviour towards trade, in $20124.9 \%$ of the firms are only importers, $2.9 \%$ only exporters while $9 \%$ are both importing and exporting services at the same time. Firms involved in trade in services account for $29 \%$ of overall employment, $40 \%$ of total turnover and $37 \%$ of total gross value added. For the firms involved in services trade, the highest shares of employment, total turnover and total gross value added belong to the firms that are both importing and exporting.

As mentioned, the dataset allows to geographically locate firms plants, allowing to map trade in services flows across the country. Within Great Britain, the Office of National Statistics identifies 260 British Travel To Working Areas (TTWA), each defined as a geographical area within which at least 75 percent of the population live and work and representing relatively self-contained autonomous labour markets rather than administrative boundaries (Edgell and McQuaid, 2011). ${ }^{14}$ As shown in figure 1, imports of services are scattered differently across Great Britain and higher flows of services imports are concentrated in the South of England and in the West Midlands, followed by part of Scotland and of Northern England.

Stylized facts presented in the present section highlight few important characteristics of trade in services, of the firms involved in it and drive the following empirical analysis. First, trade in services is mainly of intermediates of production and regards all the industries of the economy. Firms export, and therefore produce, services that are different from their main industry of production (the one the firm is registered in). The offshoring of services, defined as the import of intermediates from abroad, can then have opposite effect: substitution, replacing services previously produced by the firms, and complementarity, as part of the overall production process of a firm. Services offshoring is concentrated in some areas of Great Britain highlighting the different exposure to services offshoring of each region. Sector local areas are exposed differently to services offshoring, with intensities depending on the characteristics of the firms in each sector and local area. Further, firms that are directly involved in services offshoring are larger, pay higher wages and are more productive than the other firms in the same sector.

\footnotetext{
14 "The current criteria for defining TTWAs is that generally at least $75 \%$ of an area's resident workforce, work in the area and at least $75 \%$ of the people who work in the area also live in the area. The area must also have a working population of at least 3,500. However, for areas with a working population in excess of 25,000, self-containment rates as low as $66.7 \%$ are accepted. TTWA boundaries are non-overlapping, are contiguous and cover the whole of the UK. TTWAs do cross national boundaries, although no account is taken of commuting between Northern Ireland and the Republic of Ireland." Source: ONS.
} 


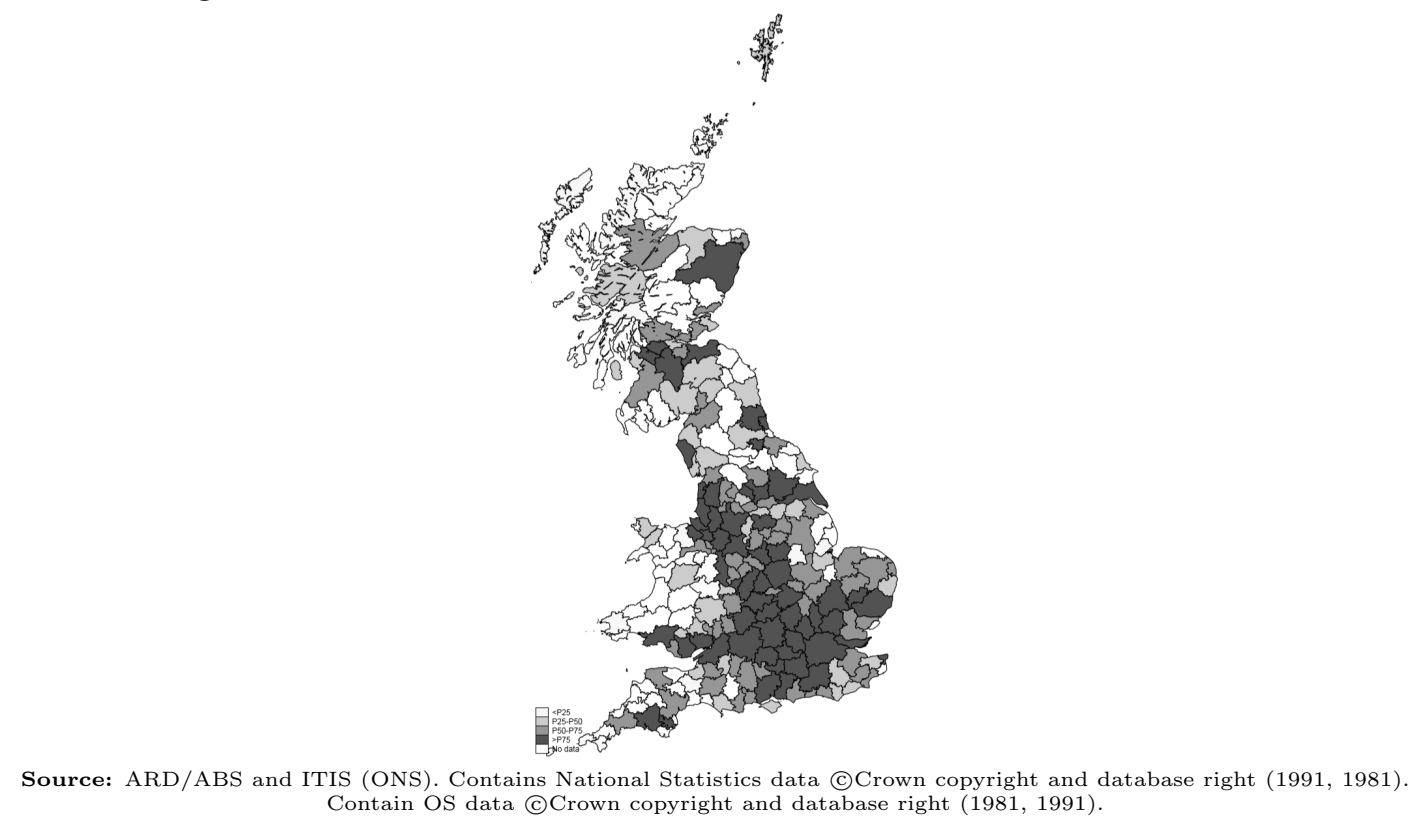
Contain OS data (C) Crown copyright and database right $(1981,1991)$

\section{Effects of services offshoring on local labour markets}

Following the theoretical framework provided by Grossman and Rossi-Hansberg (2008), firms decide to import a service if this is cost optimizing (and therefore maximizing the firm's profits). In terms of employment, firms that import services directly face two opposite effects: the substitution effect, leading to a decrease in employment and average wages, and the productivity effect, which counterbalances the losses as overall production increases (Grossman and Rossi-Hansberg, 2008). At the same time, firms not involved in services offshoring might be affected by the behaviour of importing firms indirectly through increased competition of the market (Egger et al., 2015; Autor et al., 2013) and spillover effects (e.g., supply chain, productivity or imitation).

Let us consider the following example and let assume that a local labour market is composed of two car manufacturers, A and B. At one point firm A starts importing accounting services, therefore becoming more productive as showed in Grossman and Rossi-Hansberg (2008). The firm that is not importing services (firm B) is hence indirectly affected through the increase in competition in the car manufacturing market as showed in Egger et al. (2015). At the same time however, firm B might imitate firm A and starts to import accounting services as well (imitation effect). Or, if firm A is outsourcing part of its production to firm B, then an increase in firm A's productivity benefits firm B indirectly (supply chain effect). As well, if firm B produces any services for firm A, these might be substituted with the now imported services leading to a decrease in firm B's demand (substitution effect). Finally, if firm A displace some workers as consequence of services offshoring, firm B could re-employ them changing the composition of its workforce. The aim of this paper is to measure the effects of services offshoring on the average effects within the local labour market and on both firm A 
and firm B.

Local labour markets are defined as the sector-local area (as geographical area) where the firms importing services are located. The direct and indirect effects of services offshoring are then measured for the workers and firms (offshoring and non-offshoring) located in any particular sector and local area. ${ }^{15}$ I assume workers and firms not to move between local areas, which is what travel to work areas were designed to represent by statistical authorities, consistent with recent spatial economics literature (Adão et al., 2019a; Caliendo et al., 2019). Further, workers are assumed to be static in their sector of employment, an assumption that is supported by recent empirical evidence (Dauth et al., 2017; Curuk and Vannoorenberghe, 2017).

I exploit the variation of employment and average wage between local labour markets that stem from the fact that, depending on the characteristics of the firms that it hosts, each local labour market has different offshoring of services. For each local area $k$ and sector $j$ the exposure to offshoring is computed aggregating firms' import of services following the specification:

$$
O F F_{j k t}=\sum_{i} \text { Imports }_{i j k t}
$$

where Imports $_{i j k t}$ indicates the overall imports of services of firm $i$ located in sector $j$ local area $k$ at time $t$. Therefore, local labour market offshoring increases if firms in sector $j$ local area $k$ rise imports of services at time $t$, differentiating between local areas whose firms have different trade behaviour.

The services that firms are importing might be either complements or substitutes to their production. I hence distinguish between broad and narrow offshoring following the specification as in Hummels et al. (2014). Broad offshoring is defined as the overall imports of services of a firm with no distinction on the type of service imported, hence including both the complements and substitutes. Narrow offshoring, instead, is restricted to the import of services that are in the same category of firm's outputs. This latter definition further capture the import competition effect of offshoring as highlighted in Bernard et al. (2020).

In defining the narrow offshoring two caveats occur. Firstly, services trade classification differs from the standard industry classification. I therefore construct a conversion table (A.3 in appendix) which allows to merge the types of services imported and firms' industry classification. Further, the data available do not allow to identify the whole production portfolio of a firm but only the main product (which corresponds to the industry classification a firm is registered in). I hence assume that if a firm is exporting a service, it is also producing that service. The latter assumption further allows to account for the substitution effects of services for firms registered in the manufacturing industry. This methodology is preferred to the use of industry level input output table as it allows to account for

\footnotetext{
${ }^{15}$ The definition of local labour market is similar to the unit of analysis as in Ottaviano et al. (2018).
} 
firms' heterogeneity in the production process, similarly to Hummels et al. (2014).

Table A.4 reports the descriptive statistics of the share of broad offshoring and narrow offshoring for each type of service and each firm. On average, each imported service accounts for $18 \%$ of total imports ("Share of Broad Offshoring" in the table) and $6 \%$ when looking at the services competing with firms' portfolio ("Share of Narrow Offshoring"). Hence, inputs of production not competing with firms' output account for most of the firms' services imports. Firms offshore more than one service and the composition varies across industries: on average each service accounts for $64 \%$ of total imports, with lower values in the services industry (58\%) than in the manufacturing (70\%) (table A.4, "Share of Imports on Total Trade"). Indeed, the granularity of services classification is much coarser than the goods one such that narrow offshoring might be smaller in reality. However, the data employed distinguish between 52 different services, the most detailed current available classification at this point in time.

\subsection{Local labour market analysis}

The first aim of the empirical analysis is to establish a causal impact of services offshoring on average local labour market outcomes. The unit of analysis is the sector local labour market where the firms offshoring services are located and the dependent variables are measured as weighted averages of firms' information within a sector-local area. At this stage this methodology is preferred to the firm-level analysis for mainly two reasons. Firstly, the structure of the data (unbalanced panel) does not allow to completely account for firms' characteristics and fixed effects. Further, the average outcome variables are computed using population weights such that the results are, on principle, comparable to firm-level ones. ${ }^{16}$

The regression equation takes the form:

$$
\ln y_{j k t}=\beta_{0}+\beta_{1} \ln O F F_{j k t}+\boldsymbol{\beta}_{\mathbf{j k t}}+\varphi_{j t}+\psi_{k t}+\epsilon_{j k t},
$$

where $\ln y_{j k t}$ indicates the logarithm of labour market outcome $y$ in sector $j$, local area $k$, at time $t$ and $\operatorname{lnOFF} F_{j k t}$ is the logarithm of sector $j$ local area $k$ offshoring of services at time $t$.

Following earlier literature, the vector $\mathbf{x}_{\mathbf{j k t}}$ includes observable time-varying variables at the sector local area level as the expenditure in computer software and local area's share of British owned firms. The expenditure in computer software controls for the substitutability between workers and computers (Ebestein et al., 2014) that might reduce employment of certain skills, further lagged by one year to avoid correlation with the measure of offshoring. This measure can be seen as proxy for skill biased technological changes (SBTC), hence controlling for employment changes in sectors intensively using

\footnotetext{
${ }^{16}$ To complement the analysis, section 5 presents the firm-level investigation exploiting the panel dimension of the data.
} 
skills most affected by technological changes (see Katz et al. (1999) for a complete review). The share of British owned firms in the sector-local area controls for the presence of multinationals which tend to be more productive and will hence affect both employment and wages (Criscuolo and Martin, 2009).

Local area-year fixed effects $\left(\psi_{k t}\right)$ are included to control for changes in employment and wages that might occur in a particular year in a local area, e.g. the implementation of a regional policy, or increase in immigration flows in the local area. Similarly, sector-year fixed effects $\left(\varphi_{j t}\right)$ control for yearly changes at the sector level, e.g. new technologies or negative demand shocks. Further, due to local area-time and sector-time fixed effects, it is not necessary to normalise the offshoring measure by sector or local areas characteristics. The residual is clustered at the local area and sectoral level using the specification as in Correia (2014), which allows to combine multi-way clustering with a wide range of fixed effects. The double cluster further accounts for error correlation at sector-local area level.

In the analysis, I consider as outcome variables $y_{j k t}$ three measures: average employment $\left(L_{j k t}\right)$, average wages $\left(w_{j k t}\right)$ and average productivity $\left(\right.$ out $\left._{j k t}\right)$ in sector $j$ in local area $k$ at time $t$. Sector-local area employment $\left(L_{j k t}\right)$ is obtained averaging firms' employment at the sector $j$ local area $k$ level in each year $t$. Average wage is measured computing for each firm the ratio of total wage bill and total employment $\left(w_{i j k t}=\frac{W_{i j k t}}{L_{i j k t}}\right)$, then averaged within a sector-local area $j k$ at time $t$. Finally, average productivity $\left(\right.$ out $\left._{j k t}\right)$ is measured as the mean of firms' gross value added at market prices per worker in a sector $j$ local area $k$ at time $t$.

\section{Endogeneity}

The set of fixed effects (local area-time and sector-time) mitigate potential endogeneity of the analysis, e.g. the opening of new infrastructures (airports, train stations enlargements, etc.) in a local area boosting outputs, offshoring of services and labour outcomes. However, an unobservable time-varying factor might be affecting imports of services and the dependent variables at the same time, e.g. the opening of a new production plant increasing the demand of a final product which simultaneously increases offshoring, employment and wages. As well, the fixed effects structure might fail to control for non-proportional shocks. E.g. A national shock leading to a reduction in a particular sector might deflate exponentially employment, wages and services offshoring in some local areas with higher concentration of firms in the affected sector.

To address potential endogeneity issues and exclude any reverse causality between services offshoring and local labour market outcomes, I implement an instrumental variable strategy. Specifically, offshoring of services is instrumented with total imports of services from selected exporting countries (the US, Germany, France, Ireland and the Netherlands) in selected importing countries (Australia, Canada, Japan and South Korea). The exporting countries (the US, Germany, France, Ireland and the Netherlands) are the UK main trade in services partners and among the biggest exporters of services 
in the World. The importing countries (Australia, Canada, Japan and South Korea) are a selection of advanced economies similar to the UK which are not part of the EU single market.

The intuition is that increases in industry imports of intermediate services in other high income importing countries follow a path similar to the one in the UK. It is reasonable to assume that the expansion of the services sector in the exporting countries is due to technological changes and shifts in the production process towards the service sector (see Dauth et al., 2017 for Germany), and not due to increased demand for service imports. As the exporting countries become more competitive in services production, they will export more, including to Australia, Canada, Japan and South Korea. Therefore the instrument captures changes and regularities in the pattern of services trade, while unlikely to be caused by British sector-local area labour market outcomes.

Information on imports of intermediates services in Australia, Canada, Japan and South Korea from the selected exporting countries come from the World Input-Output Database (WIOD), publicly available for the years 2000-2014. ${ }^{17}$ For each country-sector, the dataset contains information on the value and country of origin of each intermediate product used in the production process.

The instrument is taking the following form:

$$
O F F_{j k t}^{o}=\frac{L_{j k}}{L_{j}} M_{j t-1}^{o}
$$

where $M_{j t-1}^{o}$ indicates imports of intermediate services in sector $j$ at time $t$ from the exporting countries to the importing countries listed above, lagged by one year. Industry imports are allocated in each local area depending on the share of sector employment in a local area $\left(L_{j k}\right)$ on total national sector employment $\left(L_{j}\right)$ one year before the beginning of the analysis (1999).

The industry variation in the instrument comes from countries expanding their services sector because of new technologies (e.g. faster internet, virtual conferences, etc.), lower cost of trade (e.g. faster and cheaper travel) and increase in the agreements on trade in services. E.g., the increase in the imports of engineering services from Germany in the car manufacturing sector reflects the expansion of German engineering services due to higher investment in $R \& D$, trade agreements recognizing foreign engineering qualification and the possibility for German engineers to travel more easily.

The variation across local labour markets, instead, comes from different employment shares one year before the beginning of the analysis. Employment share as allocation term is preferable to the initial share of imports of services (as in Hummels et al. (2014)) mainly for the nature of trade in services. In 1999 few firms were involved in services offshoring and concentrated in a few areas of the country. Constructing the allocation term with initial import share would substantially limit the sample analysis and generate noisy shares. The intuition of the allocation term using employment is that areas with larger employment, have larger firms and attract larger shares of services imports.

\footnotetext{
${ }^{17}$ See Timmer et al. (2015).
} 
To satisfy the exogeneity condition assumption of the $I^{18}$ I test whether a channel exists other than sector local area exposure to offshoring through which imports of services in other high-income countries affect local employment and wages. When regressing the logarithm of labour market outcomes with the logarithm of imports of services in Australia, Canada, Japan and South Korea for a sample composed only of non-offshoring sector local areas, results are non-significant. ${ }^{19}$

Recent econometric literature (Goldsmith-Pinkham et al., 2020; Jaeger et al., 2018) points at the exogeneity of the share (in this case the sector employment share $\frac{L_{j k 1999}}{L_{j 1999}}$ ) as the main weakness of instruments using local market share to assigned national statistics (shift-share instruments or Bartikstyle instruments). Differently from the cases analyzed in Goldsmith-Pinkham et al. (2020) and Jaeger et al. (2018), in this application, the shares are sector-local area allocation terms, and the variation of the instrument comes mainly from the shock (increase in countries supply), consistent with Adão et al. (2019b) and Borusyak et al. (ming).

However, enough arguments exist to show significant exogeneity of $\frac{L_{j k 1999}}{L_{j 1999}}$ with the outcome variables. Both the first stage and the second stage regressions include time-varying control variables at the sector-local area. Therefore the model includes observable characteristics at the sector-local area that might determine higher shares in the first place. Further, sector employment share is computed for the base year and not updated, such that any sector-local area shocks in subsequent periods do not affect the allocation of the instrument.

At the same time, the requirements as in Borusyak et al. (ming) are satisfied: The instrument looks at the shocks at the industry level on the supply side, leaving out any UK internal dynamics and discounting for any EU trends (all importing countries are not part of the EU single market). Further, the shocks are not UK specific as the increase in the supply from the US, Germany, France, Ireland and the Netherlands affects all economies. Finally, using control variables and clustering the error at the sector local area level, allows controlling for bias in the confidence interval generated by shift-share instruments as demonstrated by Adão et al. (2019b).

\subsection{Results}

As already noted, the dependent and explanatory variables are expressed in logarithms, therefore the coefficient of interest $\beta_{1}$ can be interpreted as the elasticity of local employment (or wages) to services offshoring (equation 2). Based on the theoretical predictions, the net effect of services offshoring on both employment and average wages in a sector local area is ambiguous: Depending on the number of firms involved in services offshoring, I would expect positive elasticities of employment and of average wage to services offshoring if the gains from firms' higher productivity are large enough to overcome

\footnotetext{
${ }^{18}$ I refer to Angrist and Pischke (2009) for an entertaining discussion on IV exclusion restriction assumption.

${ }^{19}$ The results hold either when the industry specification used is at the four or two digits level.
} 
the losses generated by the displacement of workers within a sector local area.

As shown in table 1, a 10\% increase in broad offshoring exposure of a sector-local area corresponds to an increase of $1.2 \%$ in employment (column 1, panel A). The elasticity of employment is slightly lower when including control variables: a $0.9 \%$ increase in employment for every $10 \%$ raise in services offshoring exposure of a sector-local area (column 3, panel A).

As specified in the methodology section, the OLS regression might fail to account for time-varying unobservables affecting simultaneously services offshoring and the outcome variables, leading to biased results. Accordingly, the two stages least squares approach outlined in section 3 is implemented. The instrument is significant both statistically and economically in explaining services offshoring exposure and the F-tests are well above 10, the conventional threshold value (bottom panel in table 1). The estimated employment elasticity is higher when implementing the instrument for all specifications: a $10 \%$ increase in services offshoring exposure leads to a $10.3 \%$ increase in employment (column 4$){ }^{20}$

These results suggest an under-estimation of the effects when implementing simple OLS regression. It therefore appears as if unobservables simultaneously affecting services offshoring exposure and employment are working towards a decrease in employment. If it is reverse causality that is driving the discrepancy between the OLS and IV, the results suggest that an increase in sector local area employment reduces offshoring exposure: e.g. a positive productivity shock in a sector local area might generate an increase in labour productivity, leading to a rise in local employment and therefore a decrease in the imports of services. Further, it might be the case that OLS analysis contains measurement errors of the variable of interest, explaining why the coefficients of the regression are smaller than the ones obtained through IV.

Similarly to employment, the average wage responds positively to changes in services offshoring: a $10 \%$ increase in broad offshoring corresponds to an increase of $0.2 \%$ in average wage and $0.1 \%$ when including control variables (columns 1 and 3 , table 1 panel B). As before, OLS regression underestimates the results and coefficients are larger when implementing the instrument: A 10\% increase in services offshoring exposure corresponds to an increase of $0.3 \%$ of average wage in a sectorlocal area (column 4 panel B).

As discussed previously, theory predicts that one channel through which services offshoring affects employment and wages is productivity: services offshoring increases firms' productivity, leading to expansion of a firm and therefore increasing employment and average wages. To test this theoretical prediction, panel $\mathrm{C}$ in table 1 shows the results regarding the elasticity of productivity to broad services offshoring. The coefficient is -as expected- positive and significant, with a larger magnitude when implementing the instrument: a $10 \%$ increase in services offshoring exposure leads to $0.1 \%$ increase in productivity using OLS specification (column 3, panel C) and $1.1 \%$ increase using IV

\footnotetext{
${ }^{20}$ As discussed in section B, control variables are necessary to satisfy the exogeneity assumption of the instrument. The IV specification including the full set of control variables is the preferred one.
} 
Table 1: Employment, average wage and productivity elasticity to services offshoring

\begin{tabular}{lllll}
\hline & $(1)$ & $(2)$ & $(3)$ & $(4)$ \\
& OLS & IV & OLS & IV \\
\cline { 2 - 5 } & & & & \\
A. Employment & & & & \\
Broad offshoring & $0.12^{* * *}$ & $0.99^{* * *}$ & $0.09^{* * *}$ & $1.03^{* * *}$ \\
& $(0.01)$ & $(0.10)$ & $(0.01)$ & $(0.10)$
\end{tabular}

Narrow Offshoring

$\begin{array}{llll}0.14^{* * *} & 0.20^{* * *} & 0.09^{* * *} & 0.10^{* * *} \\ (0.01) & (0.03) & (0.01) & (0.02)\end{array}$

B. Average Wage

Broad offshoring

$\begin{array}{llll}0.02^{* * *} & 0.06^{* * *} & 0.01^{* * *} & 0.03^{* * *} \\ (0.00) & (0.01) & (0.00) & (0.01)\end{array}$

Narrow Offshoring

$0.02^{* * *} \quad 0.04^{* * *} \quad 0.02^{* * *} \quad 0.03^{* * *}$

$\begin{array}{llll}(0.00) & (0.01) \quad(0.00) \quad(0.01)\end{array}$

\section{Productivity}

Broad offshoring

$\begin{array}{llll}0.02^{* * *} & 0.16^{* * *} & 0.01^{* * *} & 0.11^{* * *} \\ (0.00) & (0.03) & (0.00) & (0.04)\end{array}$

Narrow Offshoring

\begin{tabular}{ccccc} 
& $\begin{array}{lll}0.02^{* * *} \\
(0.00)\end{array}$ & $\begin{array}{l}0.04^{* *} \\
(0.01)\end{array}$ & $\begin{array}{l}0.02^{* * *} \\
(0.00)\end{array}$ & $\begin{array}{l}0.03^{*} \\
(0.01)\end{array}$ \\
\hline First Stage & & & \\
\hline $0.15^{* * *}$ & $0.11^{* * *}$ & & $1.02^{* * *}$ & \\
$(0.02)$ & $(0.01)$ & $(0.05)$ & & $1.00^{* * *}$ \\
& & & & $(0.05)$
\end{tabular}

\begin{tabular}{|c|c|c|c|c|c|c|c|c|}
\hline Ftest & & 90.14 & & 91.70 & & 347.30 & & 351.82 \\
\hline Control Variables & & & $\sqrt{ }$ & $\sqrt{ }$ & & & $\sqrt{ }$ & $\sqrt{ }$ \\
\hline Local Area \# Year & & & $\sqrt{ }$ & $\sqrt{ }$ & & & $\sqrt{ }$ & $\sqrt{ }$ \\
\hline Sector \# Year & & & $\sqrt{ }$ & $\sqrt{ }$ & & & $\sqrt{ }$ & $\sqrt{ }$ \\
\hline $\mathrm{N}$ & 386,769 & 386,769 & 386,769 & 386,769 & 368,905 & 368,905 & 368,905 & 368,905 \\
\hline
\end{tabular}

Source: Data obtained combining ARD/ABS, ITIS datasets (ONS). Standard errors in parentheses are clustered at the sector and local area level. Dependent variable: Logarithm of Employment (panel A), Logarithm of Average Wage (Panel B), Logarithm of Productivity (Panel C). Control variables: $\log$ of share of British owned firms in a sector local area and the log of expenditure in computer service, lagged 1 year. ${ }^{*}(p<0.10),{ }^{* *}(p<0.05),{ }^{* * *}(p<0.01)$ 
specification (column 4, panel C).

When limiting the analysis to narrow offshoring of services, hence the offshoring of those services competing with firms' output, similar results are obtained. ${ }^{21} \mathrm{~A} 10 \%$ increase in narrow offshoring leads to $0.9 \%$ increases in employment, $0.2 \%$ increase in average wages and $0.2 \%$ increase in productivity. Similar results are obtained when implementing the IV.

As showed in section 2 services are widely employed in all sectors of an economy. Given the possible different role within industries' supply chains, I then interact the services offshoring variable with an industry dummy variable. As shown in table A.5, manufacturing industry have an increase of employment to services offshoring $0.3 \%$ higher than the services industry (column 1 ) and 6\% (column 3) higher when restricting the sample of analysis to only the local labour markets involved in services offshoring. Differently from the employment case, manufacturing industry has an increase in average wages that is $0.1 \%$ lower than the services in both sample specifications. However, when implementing the instrumental variable, the result is statistically significant only for employment elasticity, $4.6 \%$ higher in the manufacturing industry than in the services one to a $10 \%$ increase in offshoring.

A full set of sensitivity and robustness check is carried out in order to strengthened the results (I refer to appendix $\mathrm{C}$ for a complete description). In all the specifications used, the elasticity of employment and of average wages to service offshoring is positive, supporting the main findings. Further, I extend the analysis in two direction: Firstly, narrowing the definition of services offshoring and limiting trade flows to intra-firms services exchange; and disentangling the effects by country of origin of the services. The additional analysis and discussion of the results are included in appendix D.

The size of the elasticities might look small. As a back of the envelope computation, $10 \%$ increase of services offshoring is equal to a 1 percentage point of the standard deviation of the broad offshoring measure. The elasticity of employment to such increase in services offshoring is $9 \%$ (using as result column 3 in table A.5) which corresponds roughly to 166,200 more workers per year at the national level, equal to $25 \%$ increase in overall employment between 2014-2015. ${ }^{22}$ As for average wage, the elasticity to increased services offshoring is equal to $3 \%$, which corresponds to an increase of $£ 534$ in annual wage per worker.

The scale of the results in the present paper is consistent with previous studies on services offshoring. The already cited works by Amiti and Wei (2005a,b) find that for the period 1990-2004 a $10 \%$ raise in services offshoring is associated with a $0.01 \%$ increase in the U.S. total labour market productivity and an increase of $0.6 \%$ in UK overall employment. Analysis at the national level shows that for

\footnotetext{
${ }^{21}$ The sample of firms involved in Broad and Narrow offshoring is indeed different. Table A.5 columns 5-8 in appendix shows the regression results when restricting the sample to the sector local areas that are both involved in narrow and broad offshoring.

${ }^{22}$ The back of the envelope computation is as following. $9 \%$ increase in employment corresponds to 6 more worker per firm on average. In each local labour market there are on average 21 firms and the elasticity is obtained from a sample of 1,319 local labour market per year on average. National employment statistics are obtained from the ONS Labour market statistics 2020.
} 
the US a $10 \%$ increase in services offshoring leads to an increase of high-skilled employment by $5 \%$ while decreasing low and medium skill employment by $0.1 \%$ and $0.4 \%$ respectively (Crinò, 2010). More recently, Eppinger (2019) finds that firms importing services directly in Germany increase employment by $7 \%$ to a $10 \%$ increase in services offshoring. The same order of magnitude of the elasticities is observed in Ariu et al. (2019b) which exploit the heterogeneities of the effects of services offshoring across workers using as case of study Finland.

To summarise the results, services offshoring has an overall positive effects on local labour market employment and wages. The remaining of the paper is then dedicated to explore the channels through which the positive effects occur.

\section{Quantile analysis}

In the previous section, this study shows a positive relation between services offshoring and local labour market outcomes. However, the positive elasticity has to be interpreted as of positive average effect of services offshoring on sector local areas' employment and wages. Hereafter, I explore this relationship further, seeking to establish whether services offshoring has heterogeneous effects on different quantiles of the employment and wages distributions across firms. Consistent with the aggregate analysis, I estimate the effects of services offshoring on the employment and average wage distributions within the sector local area where the importing firms are located. This way, both the direct (of the firms involved in services offshoring) and the indirect (of the firms not involved in services offshoring but located in the same sector local area) effects of services offshoring can be picked up.

Moving the analysis from aggregate to quantile estimation comes with some methodological constraints. First, conditional quantile analysis does not allow to account for error correlation. Second, conditional quantile analysis only allows to compute the effects of services offshoring on the quantiles of the overall distribution of employment and wages across sectors and local areas. However, each sector local area is characterized by a different pool of firms, and their distribution in terms of employment and wages might vary: firms at the $10^{\text {th }}$ percentile of the employment (wage) distribution in the professional services industry in London may employ a much higher number of employees (pay higher wages) than those at the $10^{\text {th }}$ percentile in, say, Cardiff. I therefore carry out the analysis implementing a new model proposed by Chetverikov et al. (2016). The model takes into account differences in the distribution of firms within each sector local area, and allows to estimate quantile effects when the treatment happens at the group level (that is, exposure to services affects the entire sector local area and not only individual firms). On a more statistical note, the methodology can account for heteroscedasticity of the error and, as it can be combined with an instrumental variable, it is suitable to address any potential endogeneity concerns.

Crucially, I exploit the fact that there is variation in the degree to which sector-local areas are 
affected by offshoring of services depending on the characteristics of the firms it contains. As in the previous case, the exposure to services offshoring is measured by aggregating firms' imports of services in any given sector local area. I implement the analysis using the broad definition of offshoring, hence accounting for the overall firms' imports of services.

Within each unit, all firms are affected by services offshoring regardless their involvement in services trade. I expect firms' employment (wages) are affected differently by services offshoring depending on the point of the employment (wage) distribution where the firms are located, as modelled by Egger et al. (2015). If the fixed costs of trade are high and only a few number of firms in each local labour market are involved in services imports, the effects of services offshoring is to increase the dispersion of firms in terms of employment and wages.

For each sector-local area and given the data available, I can compute the employment and wage distributions in each year. Following the previous example: I compute separately the exact employment and wage distributions for the professional services in London and in Cardiff. Hence, for each year I obtain the value of each percentile of the employment and wage distribution in the professional service sector both in London and Cardiff.

For each quantile I then estimate the following regression:

$$
\ln y_{j k t}^{u}=\beta^{u} \ln O F F_{j k t}+\boldsymbol{\beta} \theta_{\mathbf{j k t}}+\varphi_{k t}+\lambda_{j t}+\epsilon_{j k t}^{u}
$$

where $u$ indicates the quantile, $y$ the outcome variable in local area $k$ sector $j$ at time $t, O F F$ the sector-local area $j k$ exposure to offshoring at time $t$ and $\epsilon_{j k t}^{u}$ the error, which is clustered at the sector-local area level. Equation 4 includes local area-time fixed effects $\left(\varphi_{k t}\right)$, to account for changes in the outcome variable specific to a local area in a certain period, and sector time fixed effects $\left(\lambda_{j t}\right)$, controlling for shocks at the sector level. The vector $\theta_{\mathbf{j k t}}$ is similar to the one in equation 2 and contains time varying control variables including the share of foreign owned firms in a sector local area and the logarithm of expenditure in computer services. As in the previous section, the generic outcome variable $y$ stands for either employment or average wage.

The coefficient of interest is $\beta^{u}$, that is, the elasticity of the outcome variable to services offshoring, now computed for individual quantiles $u$ within each sector-local area. This implies that for each sector-local area, I first compute the distribution of the outcome variable $y$, and then proceed to estimating $\beta^{u}$ at different quantiles $u$ of that distribution. Returning to the example given above, the distribution of the outcome variable would be computed once for the professional services industry in London, and once for the professional services industry in Cardiff. The $10^{\text {th }}$ percentiles within each sector-local area would then be used to compute the quantile-specific elasticity of the outcome variable to services offshoring, $\beta^{10^{\text {th }}}$. 
As mentioned above, it is possible to implement the instrumental variable strategy and account for potential unobservable factors affecting the dependent and the explanatory variables at the same time. As before, sector local area services offshoring is instrumented with total imports of services from selected exporting countries (the US, Germany, France, Ireland, the Netherlands) in selected importing countries (Australia, Canada, Japan and South Korea). I refer to section 3 for a more detailed discussion of the validity of the instrument. ${ }^{23}$

\subsection{Results}

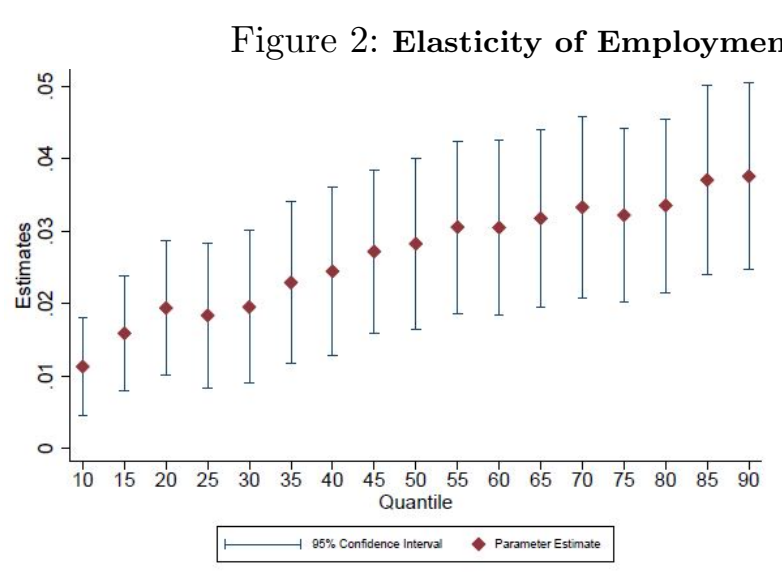

(a) Employment Elasticity - OLS

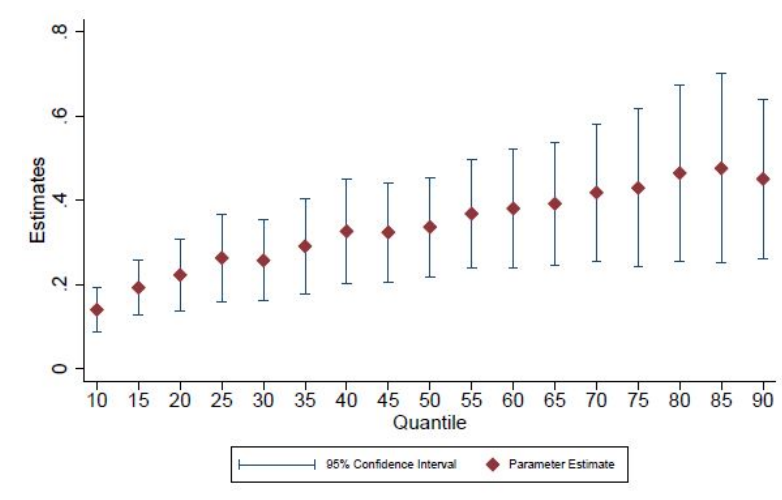

(b) Employment Elasticity-IV

Source: Data obtained combining ARD/ABS, ITIS datasets (ONS). The two graphs show the regression coefficients of employment elasticity to services offshoring by quantile. Each regression contains sector-year and local area- year fixed effects and the full set of control variables.

Figure 2(a) shows that the employment elasticity increases monotonically towards the upper quantiles of the distribution: a 10\% increase in sector-local area exposure to services offshoring comes with an increase in employment of $0.1 \%$ for small firms, that is, those at the $10^{\text {th }}$ quantile of the employment distribution. This effect is about three times larger for large firms, that is, those at the $90^{\text {th }}$ percentile of the employment distribution. The pattern of employment elasticities is similar when implementing the instrumental variable, pointing at an exacerbation of the differences between smaller and larger firms (figure $2(b)$ ).

When it comes to wages, elasticities to services offshoring are similar across quantiles of the wage distribution, with differences only in the confidence intervals of the coefficients both in the OLS (figure $3(\mathrm{a})$ ) and in the IV specification (figure $3(\mathrm{~b})) .{ }^{24}$ As the coefficients are elasticities, the results suggest that increases in services offshoring leads to larger wage gains in absolute terms for the firms at the

\footnotetext{
${ }^{23}$ Differently from the average analysis, the distributional analysis is conducted at the two digit sectoral level. For instance, the civil engineering sector is considered as a whole, instead of being divided into construction of roads and railways and construction of utility projects. This is to increase the number of observations in each sector-local area, allowing to compute precise distributions of employment and wages in each unit. Further, in the analysis all sectorlocal area with less than 10 observations are excluded from the sample, in order to obtain meaningful distribution of employment and wages.

${ }^{24}$ Here, wages are computed as the firm's wage bill divided by the total number of employees. I now refer to them as "wage" instead of "average wage" in order to avoid confusion with the aggregate analysis.
} 
top of the wage distribution compared to those at the bottom of the wage distribution.

Figure 3: Elasticity of Wages to services offshoring by quantile

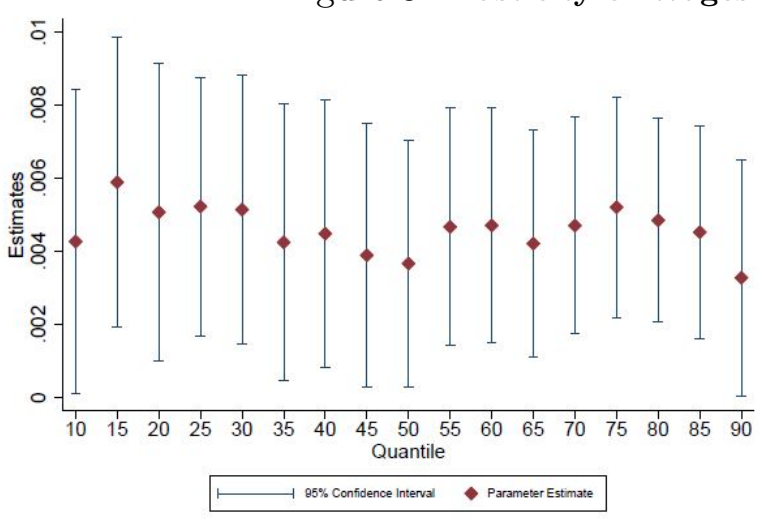

(a) Average Wage Elasticity - OLS

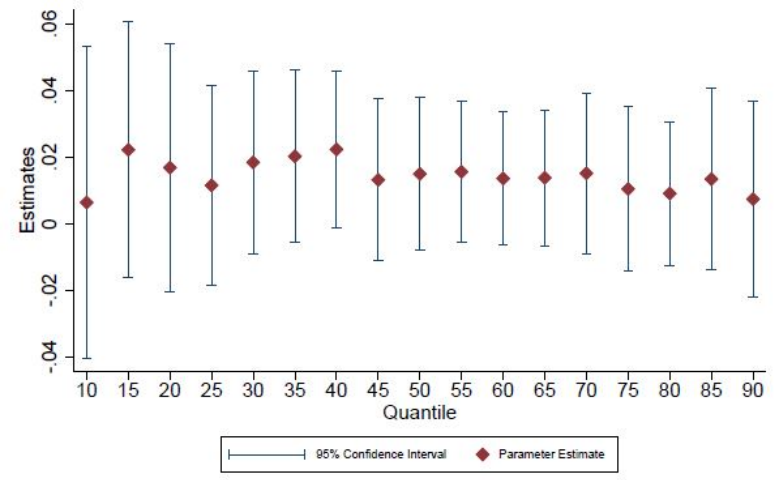

(b) Average Wage Elasticity - IV

Source: Data obtained combining ARD/ABS, ITIS datasets (ONS). The two graphs show the regression coefficients of average wage elasticity to services offshoring by quantile. Each regression contains sector-year and local area- year fixed effects and the full set of control variables.

The results in figures 2 and 3 are obtained carrying the analysis independently for each quantile. In order to compare the results between quantiles, in table A.6 the logarithm of services offshoring is interacted with the main quantiles of the employment (or wage) distribution. For both labour market outcomes the elasticities to services offshoring are higher at the top of the distribution and significantly lower at the bottom of the distribution. Therefore, the results further suggest that services offshoring stretches the differences between firms in terms of employment and wages.

In the theoretical approach discussed in section 3, productivity is a channel through which offshoring affects employment levels and wages across firms. One would expect a large overlap between the employment and wage distributions, and the distribution in terms of productivity: the most productive firms would also be expected to be the ones with the highest number of employees, and paying the highest wages. I therefore estimate the elasticity of employment and of wages at different quantiles of the productivity distribution.

The regression specification is still that described by equation 4; in this case, the coefficient of interest $\beta^{u}$ refers to the elasticity of employment (wages) to services offshoring at the $u^{\text {th }}$ decile of the productivity distribution. However, the number of firms used to compute the distribution in each unityear varies as firms enter and exit from the sample of analysis. In order to control for any bias caused by particularly highly (or scarcely) populated units of analysis, I follow Backus (2020) in including the number of firms used to compute the distribution as additional variable in the regressions. ${ }^{25}$

Second stage results are presented in figures 4(a) and 4(b). Elasticities of employment to services offshoring are stable along the productivity deciles (figure 4(a)), hence indicating higher employment gains in absolute terms for the firms at the top of the productivity distribution. At the same time, the elasticities of wage to services offshoring follows a U-shape: firms at the bottom and at the top

\footnotetext{
${ }^{25}$ Backus (2020) faces a similar problem when investigating the causal relation between productivity and competition in a case of study of the ready-mix concrete industry in the US.
} 
Figure 4: Elasticity of employment and of wages to services offshoring by productivity decile

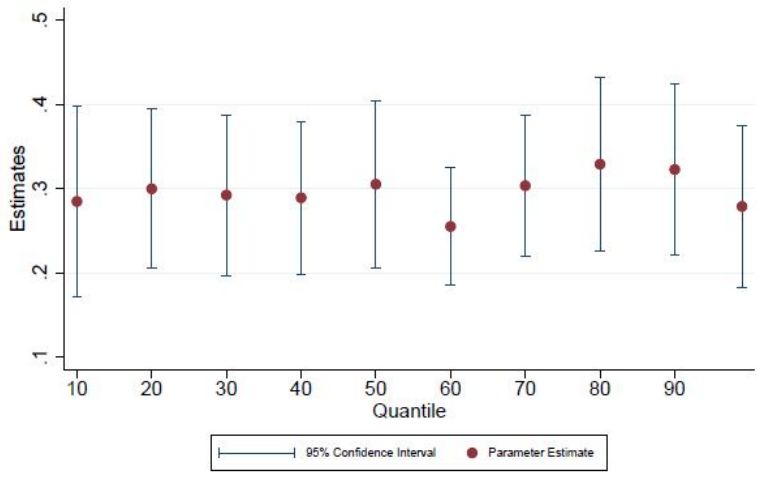

(a) Employment Elasticity

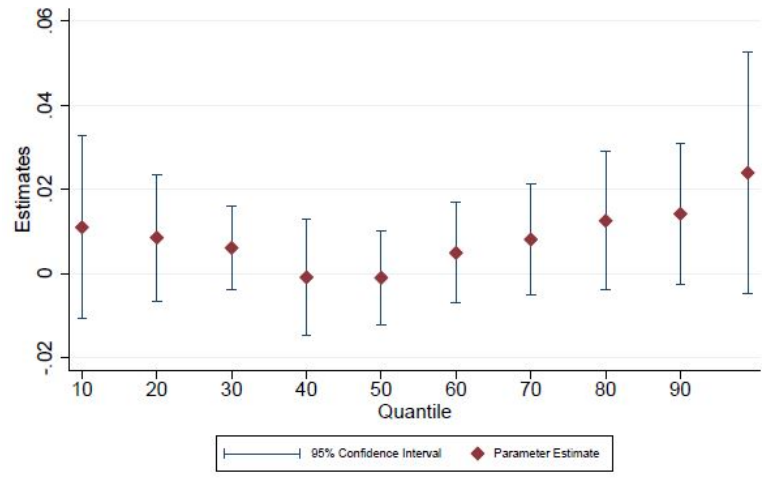

(b) Average Wage Elasticity

Source: Data obtained combining ARD/ABS, ITIS datasets (ONS). The two graphs show regression coefficients of employment and of average wage elasticity to services offshoring by productivity quantile. Each regression contains sector-year and local area- year fixed effects and the full set of control variables.

of productivity distribution have higher wage elasticities than those in the middle of the productivity distribution (figure 4(b)). However, the differences between the elasticities are not statistically significant and the results are similar to those in figure 3(b), pointing at an increase in absolute terms of the wage gap across quantiles of the productivity distribution.

I repeat the analysis of above limiting the sample to non-offshoring firms, which might be less productive than the offshoring firms. Services offshoring is computed as before aggregating firms' overall imports of services at the sector local area level. After that, for each sector local area I compute the productivity decile distribution using as sample the non-offshoring firms, then estimating the employment and wage elasticities to services offshoring at each decile (figure 5). For employment elasticities, the results are similar to those in figure 2: along the productivity distribution firms are affected differently, with most productive ones benefiting more than the least productive (figure 5(a)). At the same time, wage elasticity to services offshoring is null and not statistically significant (figure $5(\mathrm{~b}))$.

The distributions of employment, wages and productivity are computed every year in each sector local area. Firms are then allowed to move between quantiles such that the characteristics of firms on each quantile of a distribution might change over time. Therefore the analysis presented so far indicates the effects of services offshoring at the quantiles of the outcome variable distribution, but it is silent about the changes on the composition of the quantiles. As an example, from previous section I observe that the employment of the firms at the $90^{t h}$ percentile of the productivity distribution increases at the increase of services offshoring. However, it might be that the increase in employment is driven by a change in the composition of firms in the $90^{\text {th }}$ percentile of the productivity distribution due to services offshoring. The strategy implemented to control for changes in the composition of the quantiles of the productivity distribution is borrowed from the labour economics literature and most closely related to Juhn et al. (1993), who use it in their analysis of the workers' wage inequality. 
Figure 5: Elasticity of employment and of wages to services offshoring by productivity decile of nonoffshoring firms

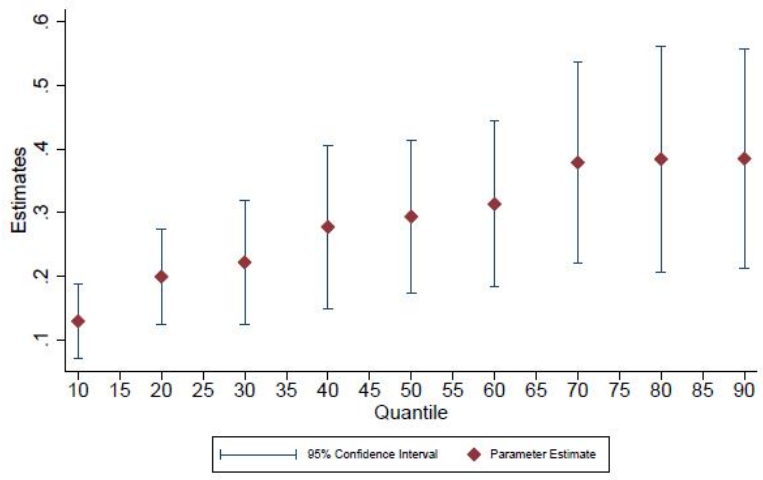

(a) Employment Elasticity

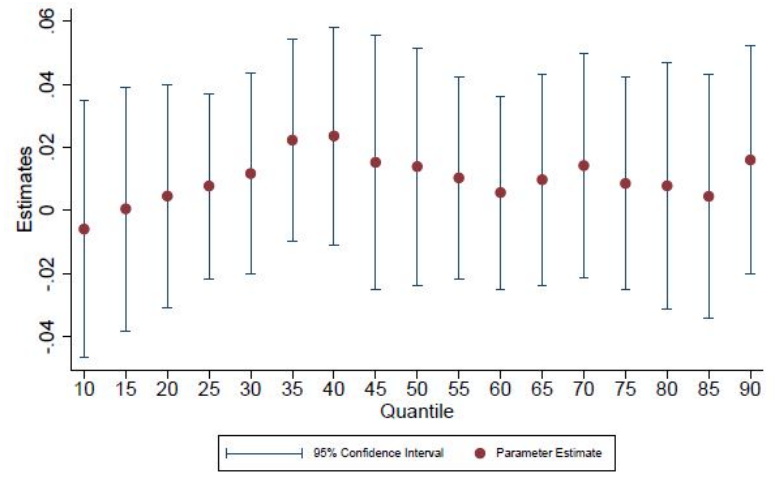

(b) Average Wage Elasticity

Source: Data obtained combining ARD/ABS, ITIS datasets (ONS). The two graphs show regression coefficients of employment and of average wage elasticity to services offshoring by productivity quantile excluding offshoring firms from the sample. Each regression contains sector-year and local area- year fixed effects and the full set of control variables.

The authors note that each quantile of the workers' wage distribution is characterised by a different composition in terms of occupations, and that it may change due to technological shocks. When estimating changes in wage inequality, they therefore need to control for changes in this composition. In order to do so, the authors propose keeping the composition of each quantile fixed to the individuals as at the beginning of the analysis. This way, the analysis abstracts from compositional effects.

However, in the present study, firms enter and exit the dataset frequently. Fixing the composition of firms to the initial productivity distribution would then lead to a substantial distortion of the sample, potentially biasing results. To overcome the problem, I proceed as follows. In order to obtain time-invariant thresholds for the quantiles, I compute the productivity distribution for all observations within a given sector-local area, irrespective of the period. Each firm is then assigned to a productivity decile based on its productivity in the first year the firm appears in the dataset, and remains in that decile in all periods that follow. Elasticities of employment and wages are then computed with the same regression specification as before (equation 4), with the exception that the composition of productivity quantiles is now kept fixed. Following the example of the previous section, firms within the professional service sector in Cardiff might move along the productivity distribution over time. I firstly compute the deciles of the productivity distribution of professional services sector in Cardiff for the whole period. Then each firm is assigned to a productivity decile depending on its productivity in the year the firm enters in the dataset.

Coefficient $\beta^{u}$ in regression 4 here quantifies the elasticity of employment or wages to services offshoring at the $u^{\text {th }}$ quantile of the productivity distribution, abstracting from changes in the composition of the decile. As before, I include the number of firms in each sector-local area as a control variable, in order to account for the entry and exit of firms in the dataset. ${ }^{26}$

\footnotetext{
${ }^{26}$ Figure 6 shows the results using as period of analysis 1999-2012.
} 
Figure 6: Elasticity of employment and wages to services offshoring by quantile with fixed productivity quantile

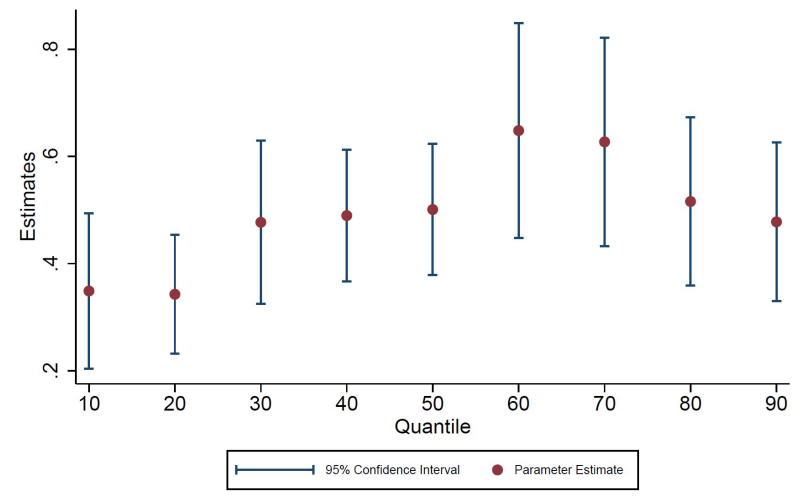

(a) Employment Elasticity

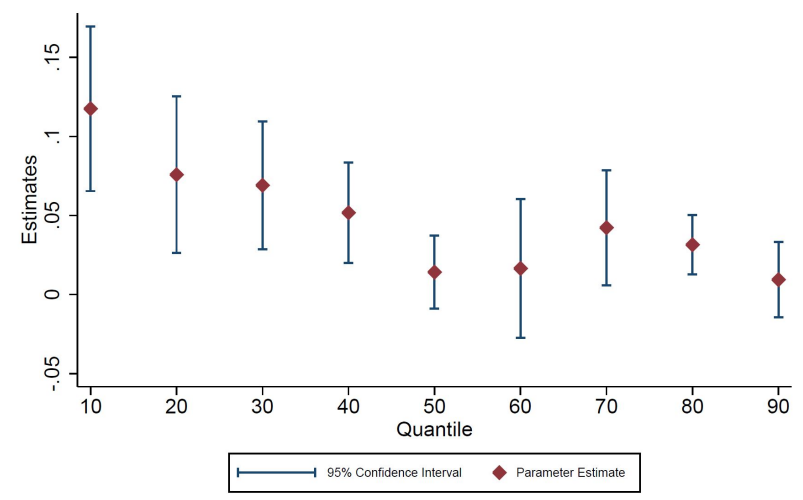

(b) Average Wage Elasticity

Source: Data obtained combining ARD/ABS, ITIS datasets (ONS). Second Stage regression coefficients of employment and average wage elasticity to services offshoring by fixed productivity decile. Each regression contains sector-year and local area- year fixed effects.

Elasticities of employment at different quantile of the productivity distribution are still different once fixing the composition of firms at the beginning of the analysis (figure 6(a)): Less productive firms have lower elasticity of employment to services offshoring than more productive firms. This suggests that even when controlling for composition effect, services offshoring leads to increase the differences in firms' employment. On the opposite, firms belonging to a lower productivity decile bin at the beginning of the analysis, have higher elasticity of wage to service offshoring than more productive ones (figure 6(b)). Therefore, in the case of wage elasticity, once accounting for the composition effect, differences between firms at different point of the productivity distribution due to services offshoring are weakened.

To summarise the findings of this section, the effects of services offshoring are heterogeneous along the employment and wage distributions. Larger firms gain more than small firms from increase in services offshoring in terms of employment both in absolute and relative terms (similar to Eppinger (2019) for German firms). As for wages, firms that are paying higher wages seems to gain more in absolute terms from services offshoring, although the nature of the data does not allow to control for workers characteristics and hence establishing which workers are gaining from services offshoring. ${ }^{27}$ The results are robust when controlling for changes in the composition of the distribution and firms' trade behaviour. Overall, it is reasonable to conclude that services offshoring increases differences between firms both in terms of employment and wages, and potentially increases workers' wage inequality - a question I leave to future research.

\footnotetext{
${ }^{27}$ I refer to section 6 for a further discussion on heterogeneous effects of services offshoring depending on workers characteristics.
} 


\section{Firm level analysis}

Within each local area and within each sector, two types of effects can be identified: A direct effect accruing to the firms directly importing services, and an indirect effect accruing to the firms that are not importing services directly but that are located in the same sector and local area as the importing firms. The positive direct effects of services offshoring on employment, productivity and average wages is extensively documented in literature (see Hummels et al. (2018) for a comprehensive overview). In contrast, the results in the present work indicate potential indirect effects (or spillovers) within a sector and local area of services offshoring. In what follows, I explore further the indirect effect of services offshoring by looking at the variation of employment and average wages at the firm level.

I firstly estimate the equivalent of equation 2 at the more granular level, extending it by an interaction term in order to delineate separate elasticities depending on firms' own imports of services. Firm-level analysis corroborates the main results of positive elasticity of employment and of average wages to services offshoring (table A.7 columns 1-4 in appendix).

The analysis hence distinguishes between firms that actively participate in services offshoring and those that don't. The exposure to services offshoring is computed by aggregating firms' services trade flows by sector local area and time, discounted by firms' own offshoring of services. If a firm is not importing services, the exposure to offshoring is equal to the offshoring measure as the one computed in section 3. Instead, if a firm is importing services directly, the offshoring exposure is computed at the net of the firm's own offshoring. This way I am able to estimate the spillover effect that services offshoring has on both importing and non importing firms. E.g. Let assume that in a local labour market there are three firms $\mathrm{A}, \mathrm{B}$ and $\mathrm{C}$ where $\mathrm{A}$ and $\mathrm{B}$ are both offshoring services. The estimation strategy here implemented estimate the spillover effect that the offshoring of services by firm B (importer) has on firm A (importer) and firm C (non importer).

The analysis is based on the equation:

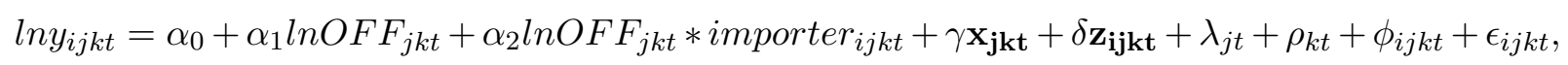

Where $y$ indicates either employment or average wage of firm $i$ (located in local area $k$ and producing in sector $j$ ) at time $t$. $O F F_{j k t}$ is the broad offshoring of services in sector $j$ local area $k$ where firm $i$ is located at time $t$, at the net of firm $i$ 's imports of services. importer $_{i j k t}$ is a dummy variable indicating whether a firm is directly involved in services offshoring or not. Two sets of control variables are included at the local area $\left(\mathbf{x}_{\mathbf{j k t}}\right)$ and at the firm $\left(\mathbf{z}_{\mathbf{i j k t}}\right)$ level. These include the share of British own firms in a local area, local area and firm's own expenditure in computer services ${ }^{28}$, foreign ownership of a firm.

\footnotetext{
${ }^{28}$ Local area expenditure in computer services is computed at the net of firms' expenditure in Computer Services
} 
Sector-time $\left(\lambda_{j t}\right)$ and local area-time $\left(\rho_{k t}\right)$ fixed effects are still included. Note that differently from the local area analysis I now include firm fixed effects $\left(\phi_{i j k t}\right)$ to account for changes on firms' characteristics through time. As in the rest of the analysis, I account for potential endogeneity issues implementing the instrumental variable strategy described in section 3, instrumenting sector local area services offshoring with the imports of intermediate services in other high income countries. Combining $\alpha_{1}$ and $\alpha_{2}$ from equation 5 allows to compute the linear relation between the elasticity of the outcome variable $y$ and the sector local area offshoring of services. I can hence distinguish the overall effects of broad offshoring of services between importer and non-importer firms.

The sign, magnitude, and nature of the indirect effect can be diverse. Firms not importing services directly and not producing the type of services imported in the sector local area, might experience positive spillover through supply chain or imitation. A firm offshoring services directly sees an increase in productivity and sales, further rising the demand from firms connected through production linkages (supply chain spillover). As well, non importing firms might replicate best practices from more productive firms (imitation spillover). On the other hand, there might be an increase of competition in the sector local labour market, as competing firms become more productive thanks to services offshoring, reducing the market share of the other firms (competition effect). At the same time, and in addition to the effects described above, firms that are competing with the services imported in the sector local area might experience adverse substitution effects à la Autor et al. (2013).

The data available do not allow to measure the intra firms flows of services within the UK, neither to measure the competition within sector local areas. Therefore it is not possible to test empirically each of the channels described above that might be driving the results. However, it is possible to distinguish the effects on the local labour markets depending on the type of services offshored and to shed some lights on the mechanisms explaining the indirect effects. In a further step I hence substitute the broad measure of offshoring in equation 5 with narrow and input offshoring. The latter is measured as the aggregate of imports of services that are not produced (nor exported) by the firms and it is obtained from the difference between broad and narrow offshoring. To control for linkages spillover, I include a firm level dummy variable taking value 1 if a firm belongs to the same enterprise group as an offshoring firm. In equation 5 I substitute the broad measures of offshoring $\left(\alpha_{1} \operatorname{lnOF} F_{j k t}\right.$ and $\alpha_{2} \operatorname{lnOF} F_{j k t} *$ importer $\left._{i j k t}\right)$ with the measure of narrow offshoring $\left(\gamma_{1} \ln O F F_{j k t}^{\text {Narrow }}+\gamma_{3} \operatorname{lnOF} F_{j k t}^{\text {Narrow }}\right.$ * importer $\left._{i j k t}\right)$ and complementary offshoring $\left(\gamma_{2} \operatorname{lnOF} F_{j k t}^{\text {Input }}+\gamma_{4} \ln O F F_{j k t}^{\text {Input }} *\right.$ importer $\left._{i j k t}\right)$. The linear combination of $\gamma_{1}$ and $\gamma_{3}$ captures the overall effects of the offshoring of substitutes of firms' production, hence accounting for the import competition effect. Instead, $\gamma_{2}$ and $\gamma_{4}$ captures the overall effects from complementary services, hence the aggregate of imitation, supply chain and competition spillover. 


\subsection{Results}

The elasticities of employment and of average wages to the offshoring of broad services are positive also when accounting for firms' characteristics and unobservable time varying (table A.8). For those firms not involved in services imports directly, however, the elasticities are lower: $10 \%$ increase in sector local area services offshoring leads to an increase in employment of $1.1 \%$ but that is $1.0 \%$ lower for non-importers than for importers (column 3 in table A.8). These results are corroborated once the instrumental variable is implemented (columns 4 in table A.8) and when computing the average wages elasticities to services offshoring (panel B). Among the firm-level control variables I include a dummy variable taking the value 1 if the firm belongs to the same enterprise group as an offshoring firm ("Same Group" in the table). Firms that belong to the same enterprise group of an offshoring firms have on average $1.2 \%$ higher employment than firms that do not have any enterprise link while there are not statistical differences in terms of average wages. However, once including firm fixed effects only the results for average wages are corroborated: to $10 \%$ increase in services offshoring corresponds an increase of $1.6 \%$ in average wages, which is $0.7 \%$ lower for non-importers than for importers. Regarding the enterprise link, the firm fixed effects reverse previous results: firms belonging to the same enterprise group have $0.2 \%$ lower employment and $0.2 \%$ higher average wages suggesting the importance of changes of labour force composition. ${ }^{29}$

When distinguishing between the type of offshoring ("Narrow" or "Input" in table A.9) the results are similar: an increase in narrow and complementary offshoring leads to an increase in employment and wages, which is higher for importers than for non-importers (columns 1 and 3). Finally, when including firm fixed effects (columns 5 and 6) results are no longer statistically significant for average wages. At the same time, an increase in $10 \%$ of narrow offshoring leads to an increase of $1.1 \%$ in employment with non-offshoring firms gaining less than offshoring firms. On the opposite, a $10 \%$ increase in complementary offshoring leads to a decrease in employment by $2.6 \%$, larger for offshoring firms than for non-offshoring firms.

As previously mentioned, the linear combination of the results in table A.8 provides a measure of the total elasticities distinguishing between importers and non importers firms, everything else equal. For the computation I use the specification as in columns 3 and 4 of tables A.8 and A.9, hence using the instrumental variable specification and including firms' time-varying controls. The specification using firms fixed effects might be preferable due to lower standard errors but it contains much lower degree of freedom and loses in the efficiency of the estimator.

Both importing and non-importing firms have positive elasticities of employment and of average wage to broad offshoring (table 2). Therefore, even if a firm is not directly involved in services offshoring, it is still affected positively by the trade behaviour of the other firms in the same local

\footnotetext{
${ }^{29}$ Section 6 explores the different effects depending on workers characteristics.
} 
Table 2: Total Effects

\begin{tabular}{lcccc}
\hline & \multicolumn{2}{c}{ Importer } & \multicolumn{2}{c}{ Non Importer } \\
\hline & Employment & Wage & Employment & Wage \\
\hline $\begin{array}{l}\text { Broad Offshoring } \\
\left(\alpha_{1}+\alpha_{2}\right)\end{array}$ & $0.43^{* * *}$ & $0.18^{* * *}$ & $0.21^{* * *}$ & $0.03^{* * *}$ \\
& $(0.03)$ & $(0.01)$ & $(0.01)$ & $(0.00)$ \\
\hline \multirow{2}{*}{$\begin{array}{l}\text { Narrow Offshoring } \\
\left(\gamma_{1}+\gamma_{3}\right)\end{array}$} & 1.48 & 0.59 & $-0.06^{* * *}$ & -0.01 \\
& $(1.05)$ & $(0.38)$ & $(0.01)$ & $(0.01)$ \\
& & & & \\
$\begin{array}{l}\text { Input Offshoring } \\
\left(\gamma_{2}+\gamma_{4}\right)\end{array}$ & -3.40 & -1.30 & $0.23^{* * *}$ & 0.01 \\
& $(2.64)$ & $(0.95)$ & $(0.02)$ & $(0.01)$ \\
\hline \hline
\end{tabular}

Source: Data obtained combining ARD/ABS, ITIS datasets (ONS). Linear combination of regression coefficients from table A. 8 column 6 for broad offshoring, column 8 for narrow and input offshoring. ${ }^{*}(p<0.10),{ }^{* *}(p<0.05),{ }^{* * *}(p<0.01)$

labour market. As well, those firms involved in services offshoring have additional gains from being exposed to the offshoring of services by firms in the same local labour market.

I hence decompose the offshoring flows between those that are substitutes of firms production and those that are complements. For non-importers the exposure to narrow offshoring has a negative impact, counterbalanced by the positive effects of input offshoring. The negative impact of narrow offshoring is in line with the import competition literature where imports of services substitute the services produced locally. At the same time, the results in table 2 suggest that the positive overall effect of services offshoring on non-importing firms is driven by what I have previously defined as the aggregate of imitation, supply chain and competition spillover (Input offshoring).

The opposite is true for importers: positive overall effects are driven by the narrow offshoring and diminished by the complementary offshoring, albeit the coefficients are not statistically significant. This latest results should not surprise as the coefficients indicate the effects of sector local area offshoring, at the net of firms' own imports, and not of the direct offshoring of services. Further, the positive sign of the elasticity of employment and wages to narrow offshoring is consistent with the findings in Bernard et al. (2020). However and differently from their paper, the data used in the present study do not allow to control for output quality and reallocation of the labour force with the firms, which are the channels driving the results in Bernard et al. (2020).

To summarise the findings of the present section, indeed firms in a local labour market benefit from services offshoring spillover. Non-offshoring firms benefit from the exposure to offshoring of services that are complementary to their production process. On the opposite, offshoring firms benefit from the narrow offshoring of services by their competitors. Unfortunately, the data available do not allow to test empirically which are the channels driving the spillover effects. Further, the services 
classification is quite wide such as the definition of narrow offshoring may still include services that actually complementary to firms' production. In the future, with improvements in data availability on trade in services, it will be possible to extend this current analysis further.

\section{Winners and losers}

The analysis has been conducted using firm-level information both for employment and wages, therefore assuming homogeneity of the workforce in each firm. In order to control for workers' individual characteristics, in a further step of the empirical analysis, I employ information on the labour markets obtained from the British Labour Force Survey (QLFS). The dataset collects UK labour force information on employment status, economic activities, individuals and household characteristics and geographical location. Although smaller in size (around 90,000 observations), QLFS is closer to a random sample (Goos and Manning, 2007) compared to other labour surveys. Unfortunately, it is not possible to merge workers in the QLFS with the respective employer in the ARD/ABS, such that the exposure of each individual to services offshoring depends only on the sector and local area of employment. Albeit imperfect, including information provided in the QLFS helps to shed some lights on the different effects of services offshoring on the labour market depending on workers' characteristics. $^{30}$ From a policy perspective, this may be particularly relevant.

In a first step, I repeat the aggregate analysis, estimating equation 1 . The results are qualitatively similar to those obtained in section 3 , in the sense that the elasticities of employment and average wages are positive with respect to increases in services offshoring (see table A.10 for the complete set of results).

\footnotetext{
${ }^{30}$ Information on employment is obtained by aggregating the number of individuals registered as employed or selfemployed in a sector-local area. Wages are obtained by averaging workers' hourly pay in each unit of analysis. Differently from the rest of the analysis, sectors are defined at one digit level, and local labour markets are larger (NUT2 of the international classification).
} 
Figure 7: Elasticity of Employment and of Hourly Pay to services offshoring by workers' characteristics

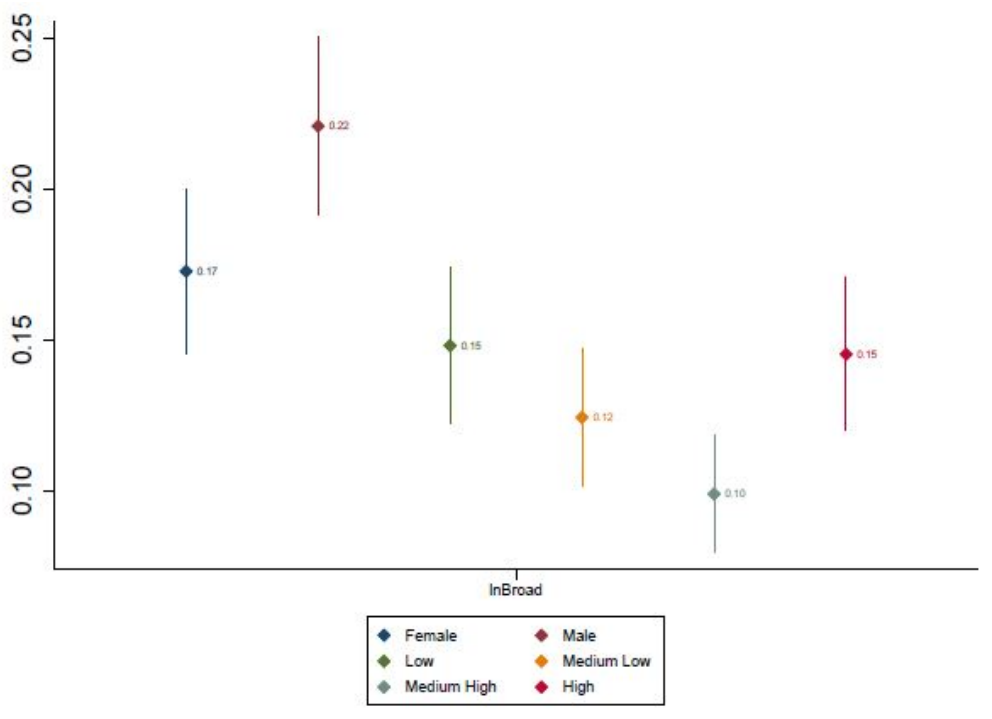

(a) Elasticity of Employment to Broad Offshoring

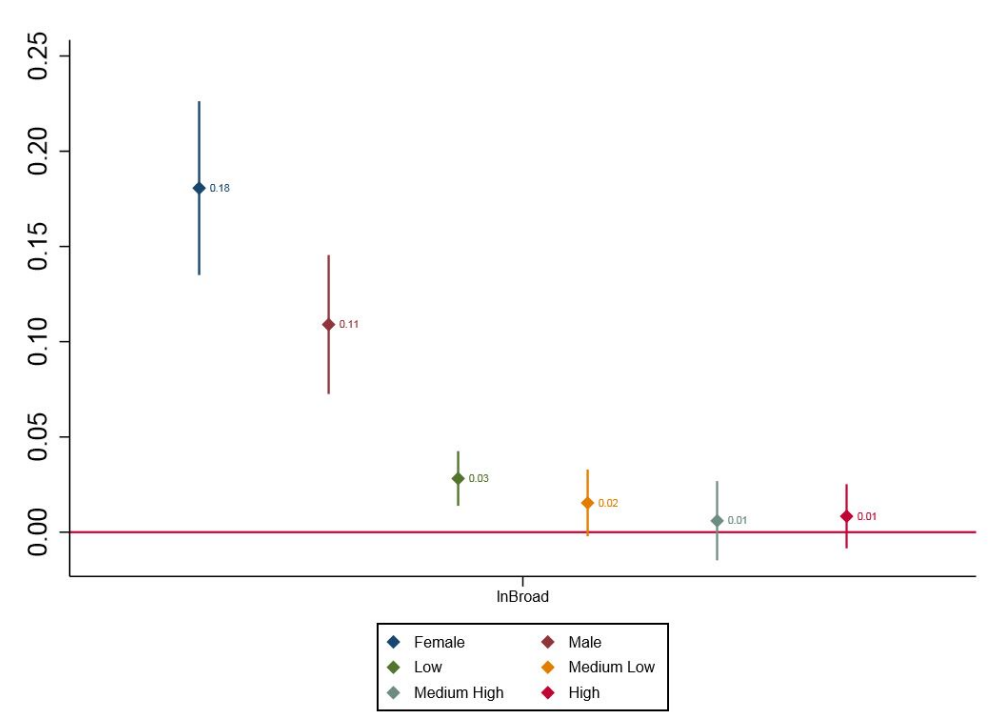

(c) Elasticity of Hourly Pay to Broad Offshoring

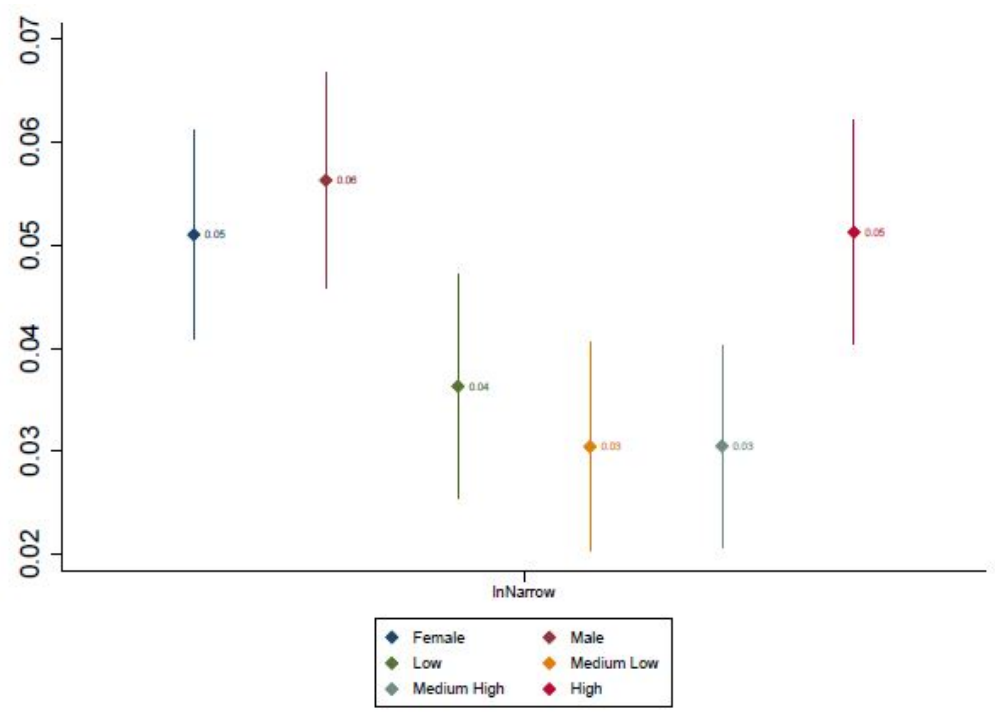

(b) Elasticity of Employment to Narrow Offshoring

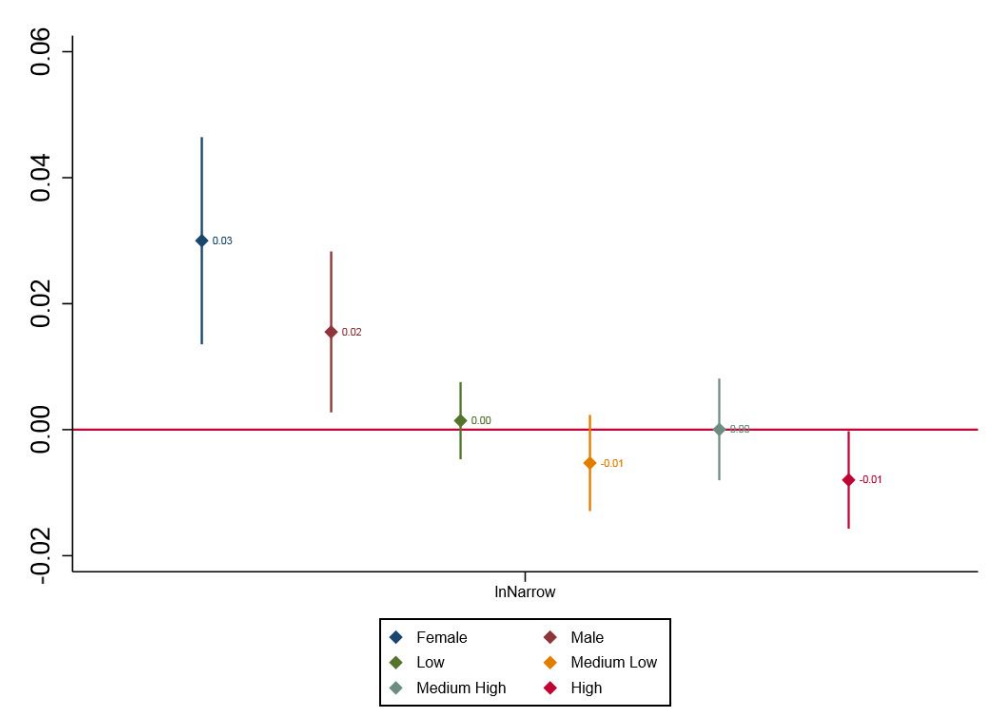

(d) Elasticity of Hourly Pay to Narrow Offshoring

Source: Data obtained combining QLFS, ARD/ABS, ITIS datasets (ONS). Dependent variables: log Employment, log Hourly Pay. The figures report second stage regressions coefficients by workers' gender and level of education. Each regression contains sector-year and local area- year fixed effects. Standard errors are robust. 
In what follows, workers are divided by gender (female and male), education level ${ }^{31}$ and occupation ${ }^{32}$ using the information contained in the QLFS. Within each sector-local area and group of workers, employment and average hourly pay are then aggregated. The analysis is then repeated by group of workers using the econometric specification defined by equation 3. Similarly to the rest of the analysis, services offshoring is divided between broad and narrow offshoring. ${ }^{33}$

The point estimate of the elasticity of employment with respect to services offshoring appears to be slightly higher for male workers than for female workers, both for narrow and broad offshoring (figures $7(\mathrm{a})$ and $7(\mathrm{~b}))$. At the same time, female workers have a slightly higher wage elasticity to service offshoring than male workers (figures 7 (c) and $7(\mathrm{~d})$ ). The sample of analysis includes only full time workers; therefore, the higher female wage elasticity to services offshoring might have to do with lower paid workers moving out of full time employment or of employment altogether.

Consistent with findings in the literature that indicate an increase in skill polarisation due to offshoring (Becker et al., 2013; Malgouyres, 2016), employment elasticity appears to differ depending on the level of education. Workers with a medium level of education have lower employment elasticity to services offshoring (broad and narrow) than those with lower and higher education (figures 7(a) and $7(b))$. As for the average wage, those workers benefiting the most from service offshoring are the highly educated, while for the other three educational categories, the estimated elasticities are close to zero (figures $7(\mathrm{c})$ and $7(\mathrm{~d})$ ).

Across occupations, manager, professionals, technical and associate professions have the highest elasticity of employment to increase in broad and narrow offshoring (figures 8(a) and 8(b)). At the same time, both employment and wages are inelastic to changes in services offshoring for those workers employed in sales and customers occupation (e.g. sales assistants), elementary occupations, leisure and caring (e.g. hospitality, hairdresser, travel agency), process and plant machinery occupations. Note that the results refer to full time employment, and that the years of analysis coincide with the introduction of zero hour contracts. This might have disproportionately affected this latter occupational categories.

\footnotetext{
${ }^{31} \mathrm{As}$ it is common in the literature, the level of education is divided in four categories: low (up to O levels and equivalent), medium low (up to A levels and equivalent), medium high (up to two years of higher education and equivalent) and high (those with a university degree and equivalent). It is important to note that dividing workers by their levels of education removes from the sample those workers not British born, as information on the level of education is not included until 2009 for this group.

${ }^{32}$ Workers' occupation is defined based on the broad one digit SOC 2010 classification, provided by the ONS. See SOC10.

${ }^{33}$ See the definition provided in section 3.
} 
Figure 8: Elasticity of Employment and of Hourly Pay to services offshoring by workers' occupation

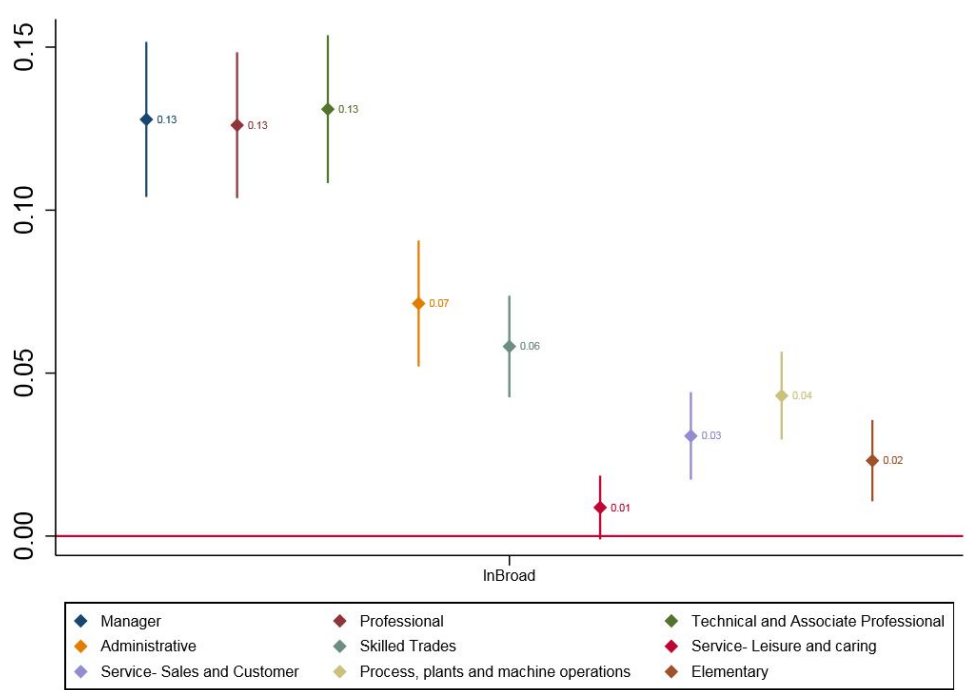

(a) Elasticity of Employment to Broad Offshoring

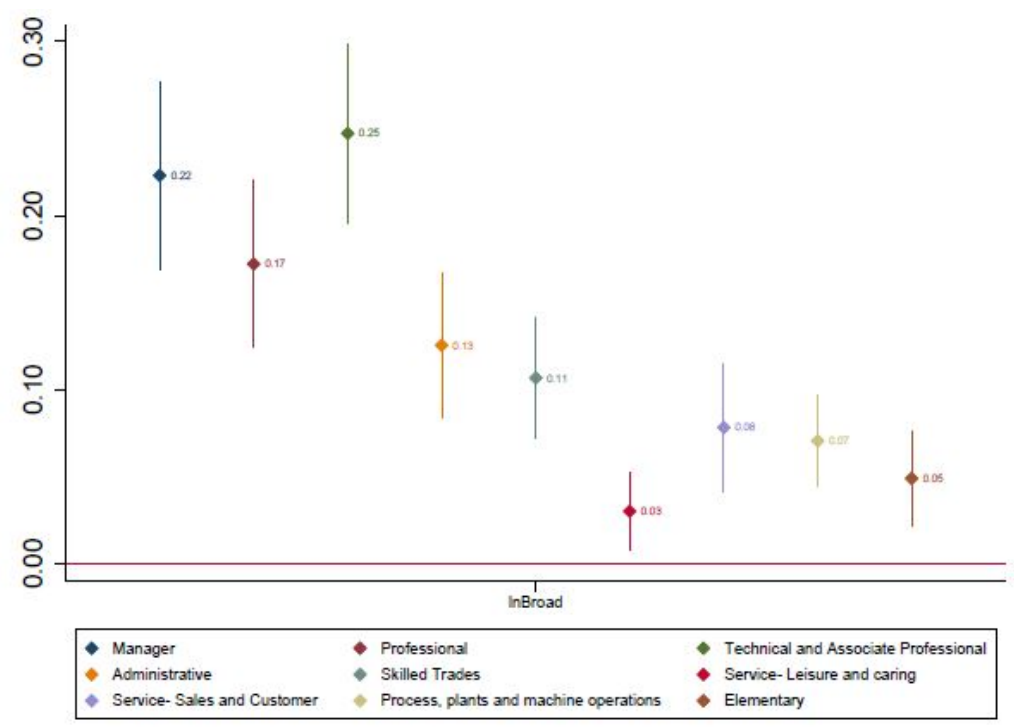

(c) Elasticity of Hourly Pay to Broad Offshoring

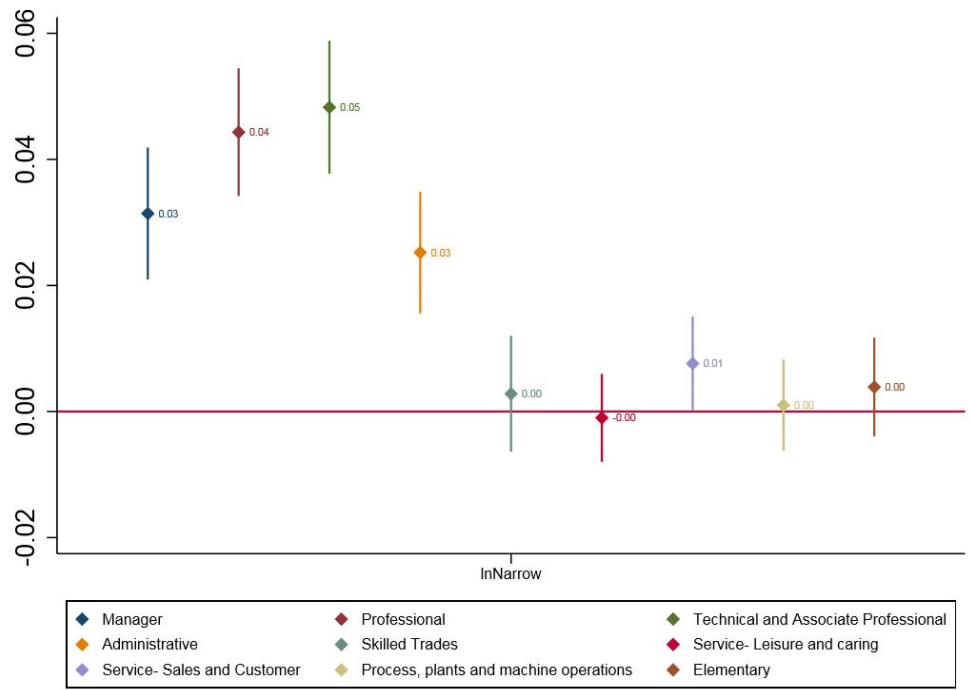

(b) Elasticity of Employment to Narrow Offshoring

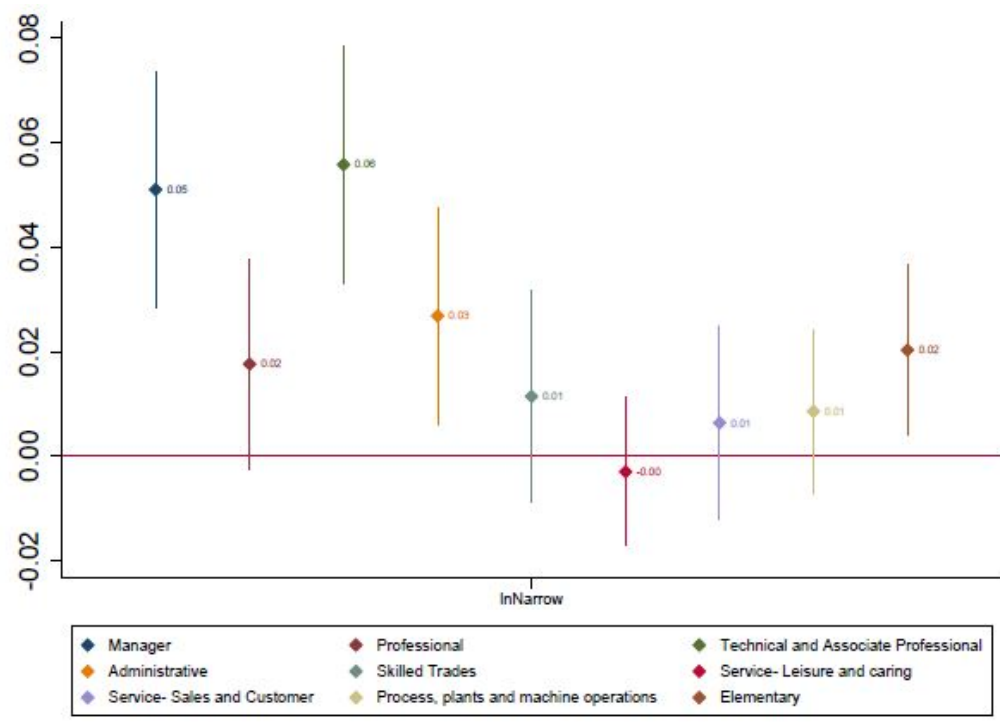

(d) Elasticity of Hourly Pay to Narrow Offshoring

Source: Data obtained combining QLFS, ARD/ABS, ITIS datasets (ONS). Dependent variables: log Employment, log Hourly Pay. Figures report second stage regressions coefficients by workers' occupation. Each regression contains sector-year and local area- year fixed effects. Standard errors are robust. 
Overall the results are consistent with the recent study by Ariu et al. (2019b) which studies the impact of services offshoring on workers employed in importing firms. Using a detailed set of employeremployee data from Finland, the authors find that services offshoring increases employment of high skill workers and those in managerial occupations, while decreases the employment of low-skilled workers. Differently from Ariu et al. (2019b), the present study includes in the sample workers employed both in offshoring and non-offshoring firms. Indeed, the results of the present section suggest that workers in non-importing firms, which experience spillover effects, are themselves indirectly affected by services offshoring. The results in the present section suggest that, overall, high skilled workers and those in the professional occupations gains more from services offshoring in terms of employment and wages, potentially increasing the inequalities within the labour force.

\section{Sector effect and local area effect, a comparison}

In section 3 I define the exposure to services offshoring as the imports on intermediate services in a sector-local area. However, a firm can be affected by the trade behaviour of other firms in the same sector or in the same geographical area. The final step of the analysis explores how results may differ depending on the definition of local labour market exposure to services offshoring (sector-local area versus sector versus local area).

As in section 3, the unit of analysis for the dependent variables is the sector local area where the firms are located. Labour market outcomes are hence computed through the weighted average of firms' information.

I then construct two new measures of offshoring at the sector level and at the local area level. These measures are similar to the one in equation 1, summing firm level information as below:

$$
\begin{aligned}
O F F_{j t} & =\sum_{i k} \text { Imports }_{i j k t}, \\
O F F_{k t} & =\sum_{i j} \text { Imports }_{i j k t}
\end{aligned}
$$

where $O F F_{j t}$ indicates the sector $j$ imports of services at time $t$ (net of sector-local area imports of services) and $O F F_{k t}$ the imports of services in local area $k$ at time $t$ (net of sector-local area imports of services). All the measures are defined as narrow offshoring, hence aggregating the import flows of the services competing with firms' production. ${ }^{34}$

In comparison with the rest of the literature, equation 6 is closely related to the import competition studies initiated by Autor et al. (2013). Similarly to these studies, the sector effect is equivalent to the import substitution - hence the imports of the same product as the one produced by the firms.

\footnotetext{
${ }^{34}$ Results using the broad definition of offshoring are similar.
} 
The empirical specification consists of implementing equation 2 for each offshoring measure (equations 6, 7 and 1 respectively). Differently from the main regression analysis, the set of fixed effects now includes local area, sector and year independently.

Table 3: Employment and average wage elasticity to services offshoring

\begin{tabular}{|c|c|c|c|c|c|c|c|}
\hline & $\begin{array}{l}(1) \\
\text { OLS }\end{array}$ & $\begin{array}{l}(2) \\
\text { IV }\end{array}$ & $\begin{array}{l}(3) \\
\text { OLS }\end{array}$ & $\begin{array}{l}\text { (4) } \\
\text { IV }\end{array}$ & $\begin{array}{l}(5) \\
\text { OLS }\end{array}$ & $\begin{array}{l}\text { (6) } \\
\text { IV }\end{array}$ & $\begin{array}{l}(7) \\
\text { OLS }\end{array}$ \\
\hline $\begin{array}{l}\text { A. Employmment } \\
\text { Sector Local Area offshoring }\end{array}$ & $\begin{array}{c}-0.00^{* * *} \\
(0.00)\end{array}$ & $\begin{array}{c}0.005^{* * *} \\
(0.01)\end{array}$ & & & & & $\begin{array}{c}-0.00^{* * *} \\
(0.00)\end{array}$ \\
\hline Local Area offshoring & & & $\begin{array}{c}0.12^{* * *} \\
(0.00)\end{array}$ & $\begin{array}{c}0.10^{* * *} \\
(0.00)\end{array}$ & & & $\begin{array}{c}0.09^{* * *} \\
(0.00)\end{array}$ \\
\hline Sector offshoring & & & & & $\begin{array}{c}-0.01^{* *} \\
(0.00)\end{array}$ & $\begin{array}{c}-0.01^{* * *} \\
(0.00)\end{array}$ & $\begin{array}{c}-0.00^{* * * *} \\
(0.00)\end{array}$ \\
\hline \multicolumn{8}{|l|}{ B. Average Wage } \\
\hline Sector Local Area offshoring & $\begin{array}{l}-0.00^{*} \\
(0.00)\end{array}$ & $\begin{array}{c}0.01^{* * *} \\
(0.00)\end{array}$ & & & & & $\begin{array}{l}-0.00 \\
(0.00)\end{array}$ \\
\hline Local Area offshoring & & & $\begin{array}{c}0.03^{* * *} \\
(0.00)\end{array}$ & $\begin{array}{c}0.02^{* * *} \\
(0.00)\end{array}$ & & & $\begin{array}{c}0.02^{* * *} \\
(0.00)\end{array}$ \\
\hline Sector offshoring & & & & & $\begin{array}{c}0.00^{* * *} \\
(0.00)\end{array}$ & $\begin{array}{c}-0.01^{* * *} \\
(0.00)\end{array}$ & $\begin{array}{c}0.00^{* * *} \\
(0.00)\end{array}$ \\
\hline IV & & $\begin{array}{c}1.00^{* * *} \\
(0.01)\end{array}$ & & $\begin{array}{c}\text { First stage } \\
0.18^{* * *} \\
(0.00)\end{array}$ & & $\begin{array}{c}0.40^{* * *} \\
(0.01) \\
\end{array}$ & \\
\hline Sector Fixed Effects & $\sqrt{ }$ & $\sqrt{ }$ & $\sqrt{ }$ & $\sqrt{ }$ & $\sqrt{ }$ & $\sqrt{ }$ & $\sqrt{ }$ \\
\hline Local Area Fixed Effects & $\sqrt{ }$ & $\sqrt{ }$ & $\sqrt{ }$ & $\sqrt{ }$ & $\sqrt{ }$ & $\sqrt{ }$ & $\sqrt{ }$ \\
\hline Year Fixed Effect & $\sqrt{ }$ & $\sqrt{ }$ & $\sqrt{ }$ & $\sqrt{ }$ & $\sqrt{ }$ & $\sqrt{ }$ & $\sqrt{ }$ \\
\hline Control Variables & $\sqrt{ }$ & $\sqrt{ }$ & $\sqrt{ }$ & $\sqrt{ }$ & $\sqrt{ }$ & $\sqrt{ }$ & $\sqrt{ }$ \\
\hline $\mathrm{N}$ & 369359 & 369359 & 369359 & 369359 & 369359 & 369359 & 369359 \\
\hline
\end{tabular}

Source: Data obtained combining ARD/ABS, ITIS datasets (ONS). Standard errors in parentheses are robust. Dependent variables: log Employment (Panel A), log Average Wage (Panel B). Control variables: log of share of British owned firms in a sector local area and the log of expenditure in computer service, lagged 1 year. ${ }^{*}(p<0.10),{ }^{* *}(p<0.05),{ }^{* * *}(p<0.01)$

As shown in table 3, of all the three offshoring measures, local area services offshoring is the only one with positive impact on employment (column 3 panel A). On the opposite, sector and sector-local area offshoring of services lead to a reduction in employment in the same period (columns 1 and 5 panel A). The results are similar when regressing all the measures in the same specification (column 7).

As in the rest of the analysis, unobservable might be affecting the measures of offshoring and local labour market outcomes. I hence implement the instrument as in equation 3 for sector local area offshoring. Similarly, the instruments for local area and sector offshoring are constructed using the 
imports of intermediates services in other high income countries. In the specific, the instrument for sector offshoring is the sector imports of intermediate services in other high income countries. As for local area offshoring, the instrument is constructed aggregating the share of sector imports of intermediate services in other high income countries in each local area. Sector shares are computed as the share of employee in a sector-local area on total number of employee in a sector in 1999.

Once implementing the instrument, sector local area and local area offshoring of services have positive coefficients, while sector offshoring is still negative. The specification using as dependent variable average wage show similar results (panel B in table 3).

Therefore, depending on the definition of local labour markets, the elasticities of employment and of average wages to services offshoring have different sign. The results of the present section show that when the exposure is measured at the sector level, the elasticities of employment and of average wages in a local labour market are negative, consistent with the literature on local labour market competition. At the same time, if the exposure is measured at the local area or sector-local area level, the elasticities are positive. The differences in the results might be methodological, where at a lower level of aggregation it is possible to explore higher variation, or due to differences in the labour market adjustments mechanisms (similar to what is found in Helm (2020) for Germany). As already mentioned, the data do not allow to link employer to employee. At this stage it is hence not possible to discern the reasons for the different results depending on the definition of local labour market offshoring of service.

\section{Conclusions}

During the last three decades, trade in services has been increasing significantly for all economies. Based on a novel detailed firm-level dataset, this paper investigates the impact of services offshoring, defined as the imports of intermediates from abroad, on local labour markets outcome in Great Britain in the period 2000-2015. By exploiting the geographical variation of firms distribution, the present work takes into account both the direct and indirect effects of services offshoring. Indeed, the study accounts for the changes on the firms not involved in services trade themselves, but that are located in the same labour market of the offshoring firms. Sector-local areas define local labour markets and the aggregate of intermediate imports from abroad within this unit, the measure of services offshoring.

At first, the paper seeks to establish a causal relation between local labour market outcomes and services offshoring. The aggregate analysis hence estimates the impact of sector-local area offshoring of services on average local employment and wages. To avoid any biases resulting from unobservable factors that may simultaneously affect local labour markets and services offshoring, I take a two-stage least squares approach. Intermediate imports of services in other high-income countries instrument for services offshoring and satisfies the critique to the Bartik-style instruments recently pointed in the 
econometric literature. OLS and IV results show that, overall, an increase in services offshoring leads to increase local employment and average wages. To examine the distributional effects of services offshoring, quantile analysis complements average analysis. Implementing a new methodology by Chetverikov et al. (2016), the results indicate that services offshoring enhances differences across firms in terms of employment and wages.

Firms offshoring services directly might drive the positive relationship between services offshoring, average employment and wages. However, the quantile analysis using as a sample only non-offshoring firms shows the same heterogeneous effects across the employment and wages distribution as the analysis employing the complete sample of firms. Exploiting firms' heterogeneities and conducting a firm-level analysis tests further this hypothesis. Results show that services offshoring affects positively firms directly involved in offshoring and those firms not involved but located in the same local labour market of the offshoring firm.

Existing literature shows that for the firms directly involved in services offshoring, the increase in productivity and the reallocation of workers within the firms lead the positive overall effects of offshoring. At the same time and the best of my knowledge, this paper is the first one showing empirically the importance of the positive indirect impact of services offshoring. The channels through which services offshoring can affect indirectly firms are production linkages (positive supply chain spillover), changes in competition in the local labour market due to higher productivity of offshoring firms (negative competition spillover), imitation spillover and higher import competition from abroad. The nature of the data does not allow to test each channel separately. However, it is possible to distinguish between the imports of intermediate services competing with firms' output and those that are complementary to the main production. Offshoring of services not competing with firms' main output lead to overall positive indirect effects, opposite to the imports of intermediates substituting firms' main output. Therefore, the aggregate of positive spillover effects (supply chain and imitation) seems to compensate the negative indirect effects of services offshoring.

Finally, carrying out the analysis by workers' characteristics and occupations reveals further heterogeneities in the effects. Both employment and wage elasticities follow a U-shaped pattern across educational levels: they react most positively for the most and the least educated workers respectively, while intermediate levels of qualification benefit the least, in relative terms. When looking at occupational categories the highest gains are for the service-sales and customer category. Linking these set of results with those from the quantile analysis suggests that services offshoring leads to an increase in inequality across workers. Because of data limitations, it is not possible to identify which type jobs are gaining and which are losing within each firm. However, it would be worthwhile to quantify the impact of services offshoring on workers' inequality. This information might shed further light on the interpretation of the results and constitutes a topic for future research. 
Highlighting empirically the importance of the indirect effect of services offshoring is the main contribution of this paper to the literature. What is most, as the case study is Great Britain, the external validity of the results might be large and apply to other OECD economies. Further, general equilibrium models as Caliendo and Parro (2015) assume input output linkages when estimating the welfare effects of trade. In this study, I include these linkages and show further indirect complementarity of services offshoring and labour market outcomes not considered in the class of theoretical models of above. Integrating general equilibrium models with the indirect effects of offshoring presented might shed further lights on the overall welfare effects of trade. A topic that I leave to my research agenda.

\section{References}

Acemoglu, D., Autor, D., Dorn, D., Hanson, G. H., and Price, B. (2016). Import competition and the Great US Sag of the 2000s. Journal of Labour Economics, 34(1):141-198.

Adão, R., Arkolakis, C., and Esposito, F. (2019a). Spatial linkages, global shocks, and local labor markets: Theory and evidence. NBER Working Paper.

Adão, R., Kolesár, M., and Morales, E. (2019b). Shift-share designs: Theory and inference. The Quarterly Journal of Economics, 134(4):1949-2010.

Amiti, M. and Wei, S.-J. (2005a). Fear of services offshoring: Is it justified? Economic Policy, CEPR., 20(42):308-347.

Amiti, M. and Wei, S.-J. (2005b). Service offshoring, productivity, and employment: Evidence from the United States (Epub). (5).

Amiti, M. and Wei, S.-J. (2009a). Does service offshoring lead to job losses? evidence from the United States. In International Trade in Services and Intangibles in the Era of Globalization, pages 227-243. University of Chicago Press.

Amiti, M. and Wei, S.-J. (2009b). Service offshoring and productivity: Evidence from the US. The World Economy, 32(2):203-220.

Angrist, J. D. and Pischke, J.-S. (2009). Mostly harmless econometrics: an empiricist's companion. Princeton Univeristy Press.

Ariu, A. (2016). Crisis-proof services: Why trade in services did not suffer during the 2008-2009 collapse. Journal of International Economics, 98:138-149.

Ariu, A., Breinlich, H., Corcos, G., and Mion, G. (2019a). The interconnections between services and goods trade at the firm-level. Journal of International Economics, 116:173-188. 
Ariu, A., Hakkala, K. N., Jensen, J. B., and Tamminen, S. (2019b). Service imports, workforce composition, and firm performance: Evidence from finnish microdata. NBER Working Paper.

Ariu, A., Mayneris, F., and Parenti, M. (2020). One way to the top: How services boost the demand for goods. Journal of International Economics, 123:103-278.

Autor, D. H., Dorn, D., and Hanson, G. H. (2013). The China Syndrome: Local labour market effects of import competition in the United States. American Economic Review, 103(6):2121-2168.

Autor, D. H., Dorn, D., and Hanson, G. H. (2016). The China shock: Learning from labor market adjustment to large changes in trade. Annual Review of Economics, 8:205-240.

Autor, D. H., Dorn, D., Hanson, G. H., and Song, J. (2014). Trade adjustment: Worker-level evidence. The Quarterly Journal of Economics, 196(4):1799-1860.

Backus, M. (2020). Why is productivity correlated with competition? Econometrica, 88(6):2415-2444.

Baldwin, R. (2016). The Great Convergence. Harvard University Press.

Baldwin, R. (2019). The globotics upheaval: Globalization, robotics, and the future of work. Oxford University Press.

Balsvik, R., Jensen, S., and Salvanes, K. G. (2015). Made in China, sold in Norway: Local labor market effects of an import shock. Journal of Public Economics, 127:137-144.

Becker, S. O., Ekholm, K., and Muendler, M.-A. (2013). Offshoring and the onshore composition of tasks and skills. Journal of International Economics, 90:91-106.

Bernard, A. B., Fort, T. C., Smeets, V., and Warzynski, F. (2020). Heterogeneous globalization: Offshoring and reorganization. NBER Working Paper.

Bernard, A. B., Smeets, V., and Warzynski, F. (2017). Rethinking de-industrialization. Economic Policy, 32(89):5-38.

Blanchard, P., Fuss, C., and Mathieu, C. (2017). Why do manufacturing firms produce services? Evidence for the servitization paradox in Belgium. National Bank of Belgium Working Paper.

Borusyak, K., Hull, P., Jaravel, X., et al. (forthcoming). Quasi-experimental shift-share research designs. Review of Economic Studies.

Breinlich, H., Soderbery, A., and Wright, G. C. (2018). From selling goods to selling services: firm responses to trade liberalization. American Economic Journal: Economic Policy, 10(4):79-108. 
Caliendo, L., Dvorkin, M., and Parro, F. (2019). Trade and labor market dynamics: General equilibrium analysis of the China trade shock. Econometrica, 87(3):741-835.

Caliendo, L. and Parro, F. (2015). Estimates of the trade and welfare effects of NAFTA. The Review of Economic Studies, 82(1):1-44.

Chetverikov, D., Larsen, B., and Palmer, C. (2016). IV quantile regression for group-level treatments, with an application to the distributional effects of trade. Econometrica, 84(2):806-833.

Correia, S. (2014). Reghdfe: Stata module to perform linear or instrumental-variable regression absorbing any number of high-dimensional fixed effects. Statistical Software Components S445874, Boston College Department of Economics.

Costa, R., Dhingra, S., and Machin, S. (2019). Trade and worker deskilling. NBER Working Paper.

Crinò, R. (2008). Service offshoring and productivity in Western Europe. Economic Bullettin. Access Econ, 6:1-8.

Crinò, R. (2010). Service offshoring and white-collar employment. The Review of Economic Studies, $77(2): 595-632$.

Criscuolo, C. and Garicano, L. (2010). Offshoring and wage inequality: Using occupational licensing as a shifter of offshoring costs. American Economic Review, 100:439-443.

Criscuolo, C., Haskel, J., and Martin, R. (2004). Import competition, productivity, and restructuring in UK manufacturing. Oxford review of Economic Policy, 20(3):393-408.

Criscuolo, C. and Martin, R. (2009). Multinationals and US productivity leadership: Evidence from Great Britain. The Review of Economics and Statistics, 91(2):263-281.

Crozet, M. and Milet, E. (2017a). Should everybody be in services? The effect of servitization on manufacturing firm performance. Journal of Economics 83 Management Strategy, 26(4):820-841.

Crozet, M. D. and Milet, E. (2017b). The servitization of French manufacturing firms. In The factory-free economy: outsourcing, servitization, and the future of industry, pages 111-135. Oxford University Press.

Curuk, M. and Vannoorenberghe, G. (2017). Inter-sectoral labor reallocation in the short run: the role of occupational similarity. Journal of International Economics, 108:20-36.

Dauth, W., Findeisen, S., and Suedekum, J. (2014). The rise of the East and the Far East: German labor markets and trade integration. Journal of the European Economic Association, 12(6):16431675. 
Dauth, W., Findeisen, S., and Suedekum, J. (2017). Trade and manufacturing jobs in Germany. American Economic Review, 107(5):393-408.

Dauth, W., Findeisen, S., and Suedekum, J. (2021). Adjusting to globalization in Germany. Journal of Labor Economics, 39(1):263-302.

Donoso, V., Martin, V., and Minondo, A. (2015). Do differences in the exposure to Chinese imports lead to differences in local labour market outcomes: An analysis for Spanish provinces. Regional Studies, 49(10):1746-1764.

Ebestein, A., Harrison, A., McMillan, M., and Phillips, S. (2014). Estimating the impact of trade and offshoring on American workers using the Current Population Surveys. The Review of Economics and Statistics, 96(4):581-595.

Edgell, V. and McQuaid, R. W. (2011). Intra-regional and inter-geographical mobility. pages 152-161.

Egger, H., Kreickemeier, U., and Wrona, J. (2015). Offshoring domestic jobs. Journal of International Economics, 97(1):112-125.

Eppinger, P. S. (2019). Service Offshoring and Firm Employment. Journal of International Economics, 117:209-228.

Gheishecker, I. and Görg, H. (2011). Services offshoring and wages: Evidence from micro data. Oxford Economic Papers, 65(1):124-146.

Girma, S. and Görg, H. (2004). Outsourcing, foreign ownership and productivity: Evidence from UK establishment-level data. Review of International Economics, 12(5):817-832.

Goldsmith-Pinkham, P., Sorkin, I., and Swift, H. (2020). Bartik instruments: What, when, why, and how. American Economic Review, 110(8):2586-2624.

Goos, M. and Manning, A. (2007). Lousy and Lovely: The rising polarization of work in Britain. The Review of Economics and Statistics, 89(1):118-133.

Grossman, G. M. and Rossi-Hansberg, E. (2008). Trading tasks: A simple theory of offshoring. American Economic Review, 98(5):1978-1997.

Helm, I. (2020). National industry trade shocks, local labor markets, and agglomeration spillovers. The Review of Economics Studies.

Hijzen, A., Pisu, M., Upward, R., and Wright, P. W. (2011). Employment, job turnover, and trade in producer services: UK firm-level evidence. Canadian Journal of Economics, 44(3):1020-1043. 
Hummels, D., Jorgensen, R., Munch, J., and Xiang, C. (2014). The wage effects of offshoring: Evidence from Danish matched worker-firm data. American Economic Review, 104(6):1597-1629.

Hummels, D., Munch, J. R., and Xiang, C. (2018). Offshoring and labour market. Journal of Economic Literature, 56(3):981-1028.

Jaeger, D. A., Stuhler, J., and Ruist, J. (2018). Shift-share instruments and the impact of immigration. NBER Working Paper.

Javorcik, B., Stapleton, K., Kett, B., and O'Kane, L. (2020). Unravelling deep integration: Local labour market effects of the Brexit vote. CEPR Discussion Paper.

Juhn, C., Murphy, K. M., and Pierce, B. (1993). Wage inequality and the rise in return to skill. Journal of Political Economy, 101(3):410-442.

Katz, L. F. et al. (1999). Changes in the wage structure and earnings inequality. Handbook of Labor Economics, 3:1463-1555.

Keller, W. and Utar, H. (2016). International trade and job polarization: evidence at the worker-level. NBER Working Paper.

Liu, R. and Trefler, D. (2019). A sorted tale of globalization: White collar jobs and the rise of services offshoring. Journal of International Economics, 118:105-122.

Lodefalk, M. (2013). Servicification of manufacturing-evidence from Sweden. International Journal of Economics and Business Research, 6(1):87-113.

Malgouyres, C. (2016). The impact of Chinese import competition on the local structure of employment and wages: evidence from France. Journal of Regional Science, 57(3):411-441.

Melvin, J. R. (1989). Trade in producer services: a Heckscher-Ohlin approach. Journal of Political Economy, 97(5):1180-1196.

Neely, A., Benedetinni, O., and Visnjic, I. (2011). The servitization of manufacturing: Further evidence. Academic paper to be presented at the 18th European Operations Managment Association Conference, Cambridge.

ONS (2011). Annual respondents database, 1973-2008. Secure Data Service Access. SN:6644.

ONS (2013). United Kingdom Balance of Payment - the Pink Book.

ONS (2016). Annual business survey, 2008-2016.Secure Data Service Access. SN:7451.

ONS (2017). International trade in services, 1996-2015. Secure Data Service Access. SN:6711. 
Ottaviano, G. I., Peri, G., and Wright, G. (2018). Immigration, trade and productivity in services: Evidence from UK firms. Journal of International Economics, 112:88-108.

Timmer, M. P., Dietzenbacher, E., Los, B., Stehrer, R., and De Vries, G. J. (2015). An illustrated user guide to the world input-output database: the case of global automotive production. Review of International Economics, 23(3):575-605.

Utar, H. (2018). Workers beneath the floodgate: The impact of removing trade quotas for China on Danish workers. Review of Economics and Statistics, 100(4):631-647.

Vandermerwe, S. and Rada, J. (1988). Servitization of business: Adding value by adding services. European Managment Journal, 6(4):314-324.

Wang, Z., Wei, S.-J., Yu, X., and Zhu, K. (2018). Re-examining the effects of trading with China on local labor markets: A supply chain perspective. NBER Working Paper. 
A. Additional figures and tables

Figure A.1: Imported and Exported services contained in ITIS in 2012

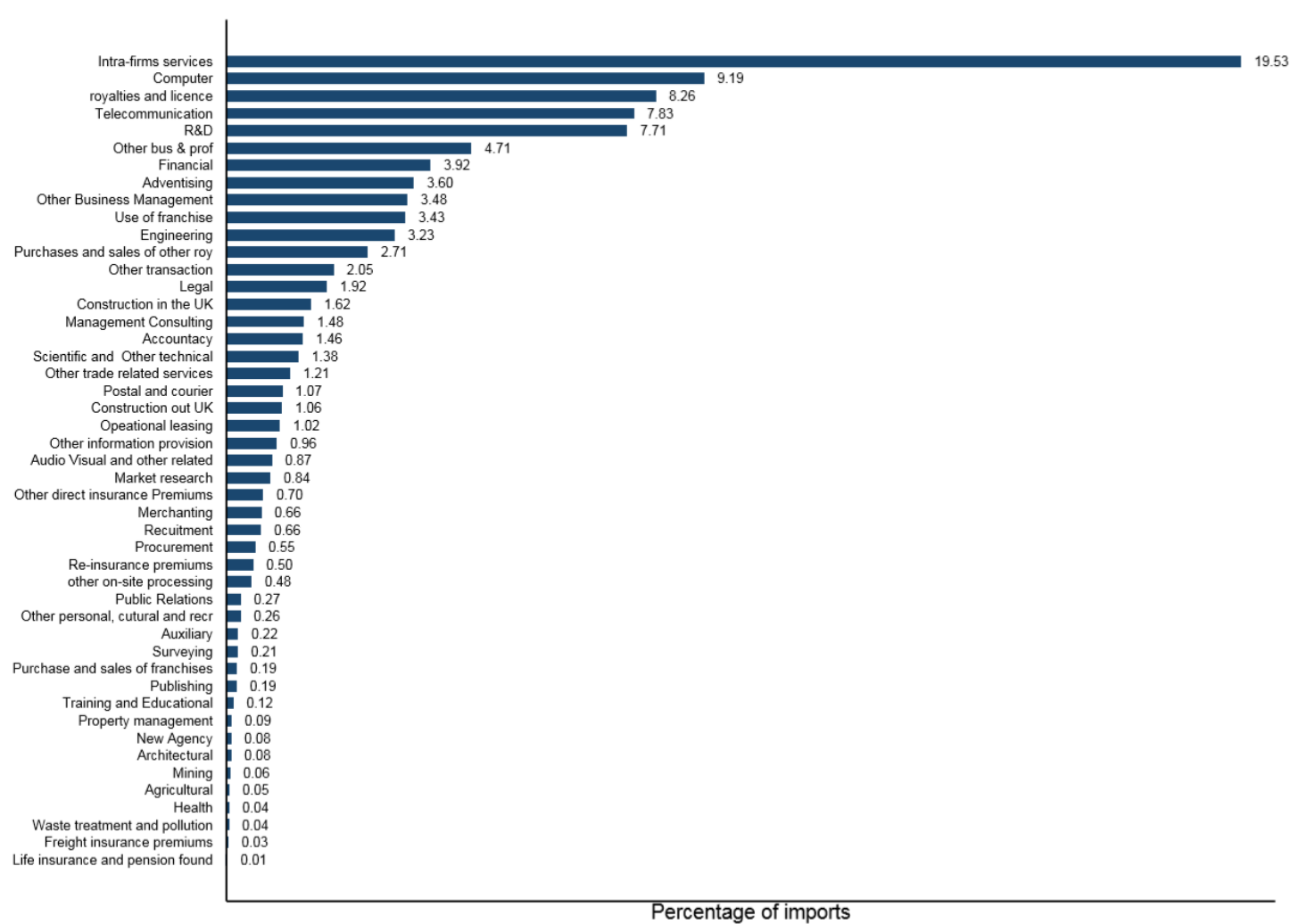

(a) Imported Services

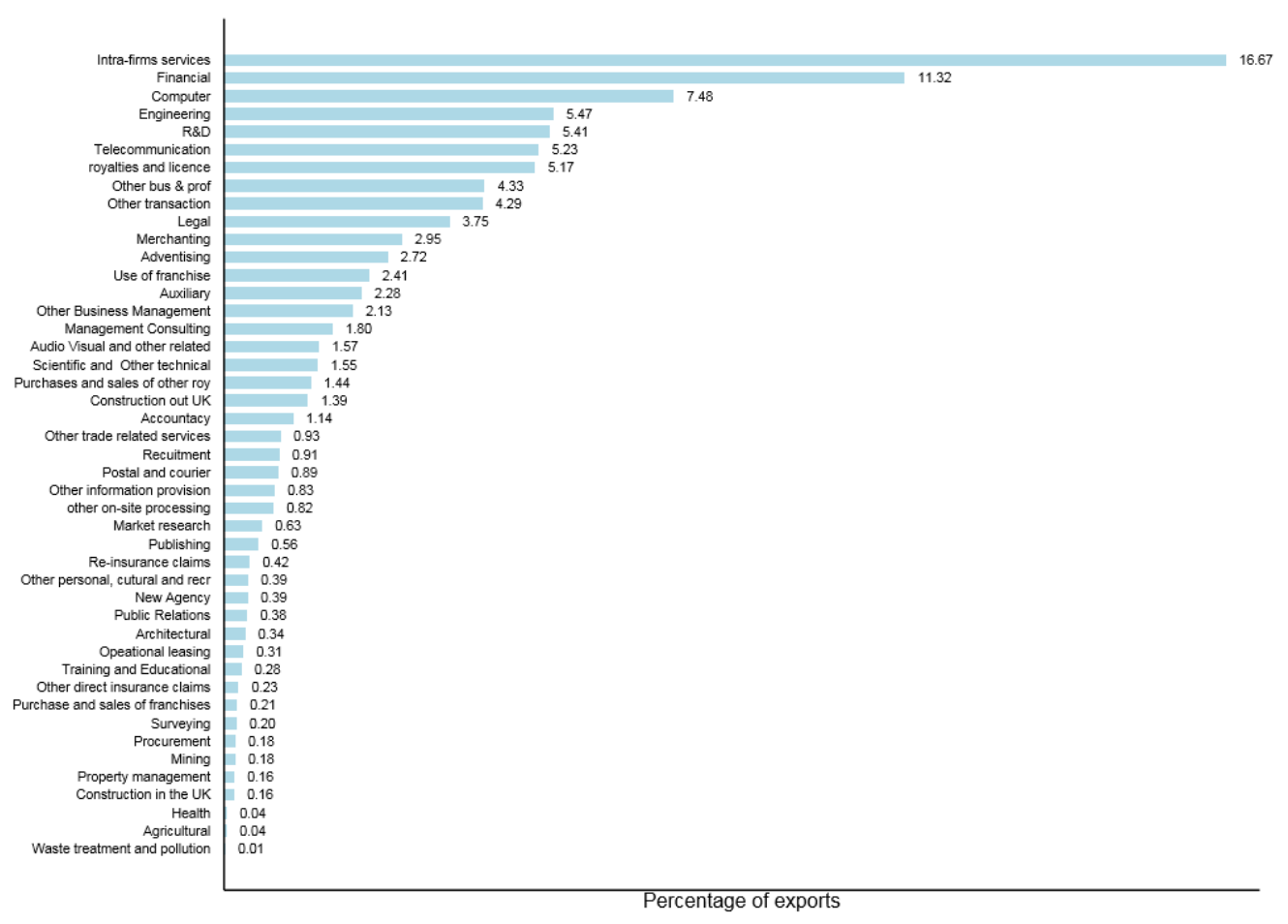

(b) Exported Services

Source: ITIS (ONS). 
Table A.1: Import and Export of services by sector in 2012

\begin{tabular}{|c|c|c|c|c|}
\hline Sector of import & Imported Service & Percentage & Exported Service & Percentage \\
\hline \multirow{3}{*}{ Agriculture \& Mining } & Professional Services & 3.52 & Professional Services & 1.22 \\
\hline & Other & 1.1 & Other & 1.26 \\
\hline & Franchise and licensing & 0.13 & & \\
\hline \multirow{3}{*}{ Manufacturing, Low Tech } & Professional Services & 1.34 & Professional Services & 6.13 \\
\hline & $\mathrm{ICT}$ & 0.92 & Waste and other on-site & 45.75 \\
\hline & Construction & 4.43 & Other & 2.13 \\
\hline \multirow{3}{*}{ Manufacturing, High Tech } & Professional Services & 5.54 & Professional Services & 2.08 \\
\hline & Franchise and licensing & 7.81 & Franchise and licensing & 6.08 \\
\hline & $\mathrm{ICT}$ & 0.54 & Waste and other on-site & 2.94 \\
\hline \multirow{3}{*}{ Commodities \& Construction } & Construction & 26.96 & Construction & 34.23 \\
\hline & Professional Services & 1.42 & Professional Services & 0.55 \\
\hline & $\mathrm{ICT}$ & 0.78 & Other & 1.74 \\
\hline \multirow{3}{*}{ Wholesale \& Retail } & Professional Services & 9.37 & Trade related & 89.46 \\
\hline & Franchise and licensing & 14.69 & Other & 60.21 \\
\hline & $\mathrm{ICT}$ & 3.7 & Professional Services & 4.28 \\
\hline \multirow{3}{*}{ Transportation \& Storage } & $\mathrm{ICT}$ & 4.2 & $\mathrm{ICT}$ & 5.7 \\
\hline & Other & 12.72 & Other & 1.04 \\
\hline & Professional Services & 0.28 & Professional Services & 0.13 \\
\hline \multirow{3}{*}{ Hospitality } & Franchise and licensing & 2.21 & Professional Services & 0.14 \\
\hline & Trade related & 7.21 & Franchise and licensing & 0.18 \\
\hline & Professional Services & 0.21 & & \\
\hline \multirow{3}{*}{ Information \& Communication } & ICT & 77.03 & ICT & 81.94 \\
\hline & Franchise and licensing & 46.27 & Franchise and licensing & 44.03 \\
\hline & Professional Services & 6.61 & Professional Services & 7.19 \\
\hline \multirow{3}{*}{ Finance \& Insurance } & Finance and insurance & 73.2 & Finance and insurance & 82.57 \\
\hline & Professional Services & 1.9 & Professional Services & 1.57 \\
\hline & $\mathrm{ICT}$ & 2.51 & ICT & 0.59 \\
\hline \multirow{3}{*}{ Real Estate } & Professional Services & 0.18 & Professional Services & 0.91 \\
\hline & Finance and insurance & 0.1 & Finance and insurance & 0.09 \\
\hline & $\mathrm{ICT}$ & 0.01 & Other & 0.23 \\
\hline \multirow{3}{*}{ Professional } & Professional Services & 62.15 & Professional Services & 67.08 \\
\hline & Franchise and licensing & 18.24 & Franchise and licensing & 29.19 \\
\hline & $\mathrm{ICT}$ & 6.96 & Other & 20.29 \\
\hline \multirow{3}{*}{ Administrative \& Support } & Professional Services & 6.14 & Professional Services & 7.77 \\
\hline & Finance and insurance & 12.96 & Finance and insurance & 9.66 \\
\hline & Franchise and licensing & 5.16 & Franchise and licensing & 5.3 \\
\hline \multirow{3}{*}{ Health \& Recreational } & Franchise and licensing & 4.18 & Personal Services & 32.63 \\
\hline & Professional Services & 0.92 & Franchise and licensing & 6.69 \\
\hline & Personal Services & 20.23 & Professional Services & 0.49 \\
\hline \multirow{3}{*}{ Other Services } & $\mathrm{ICT}$ & 0.87 & $\mathrm{ICT}$ & 0.77 \\
\hline & Professional Services & 0.39 & Finance and insurance & 0.73 \\
\hline & Finance and insurance & 1.77 & Professional Services & 0.32 \\
\hline
\end{tabular}

Source: ITIS (ONS). Column "Service" refers to the three most imported services by sector of the importing firms in 2012 . The percentage refers to the share of imports of service $i$ from sector $x$ on the overall imports of service $i$. Sector "Agriculture \& Mining" includes Fishing and Forestry. "Commodities \& Construction" includes Electricity, Water Supply and Waste Management. "Hospitality" includes Accommodation and Food Services. "Professional" includes Scientific and Technical. "Health \& Recreational" includes social works. "Personal Services" imported and exported include health and recreational services. 
Figure A.2: Percentage of Imports and Exports of services by partner country

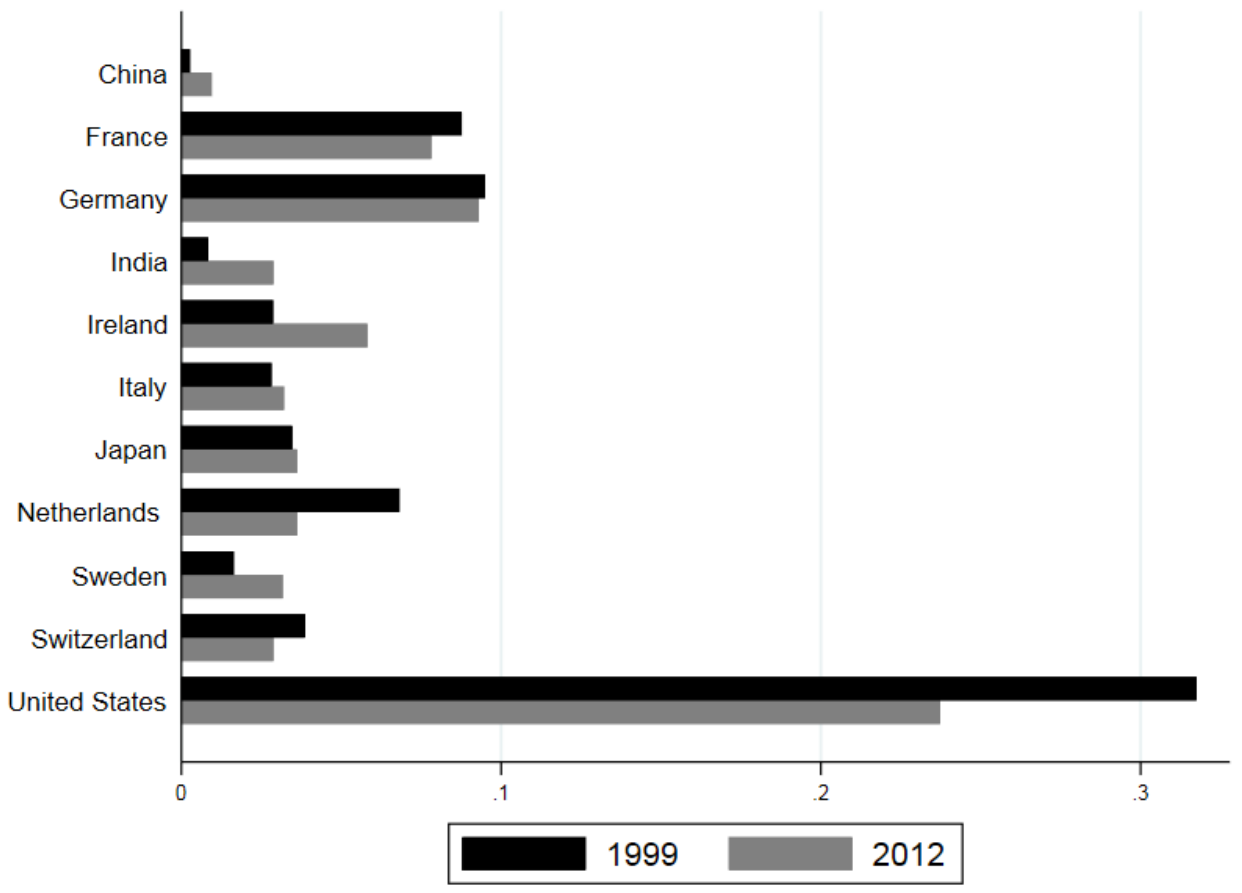

(a) Imports

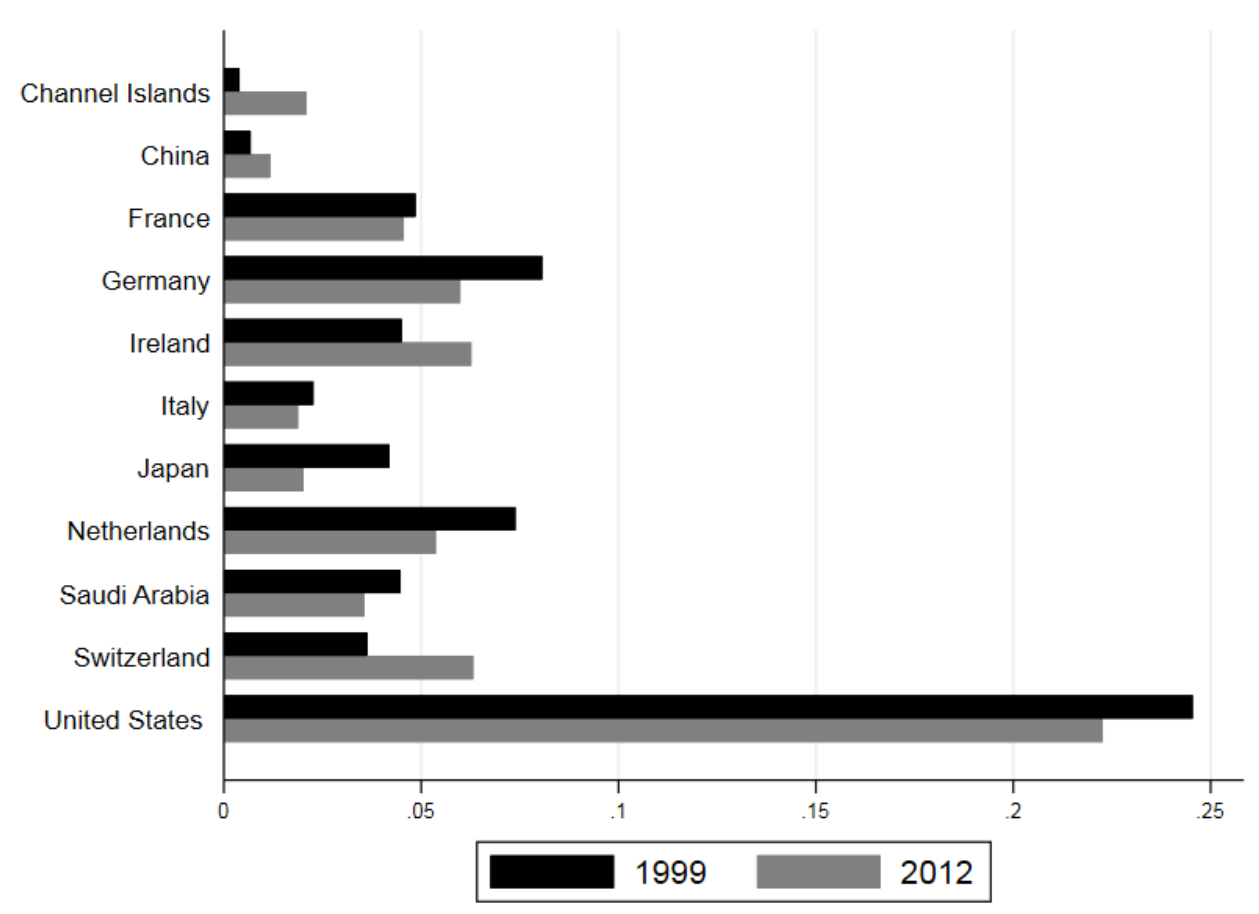

(b) Exports

Source: ITIS (ONS). 
Table A.2: Most traded services by UK partner country

\begin{tabular}{|c|c|c|c|c|}
\hline Country & Services most imported & Percentage & Services Most Exported & Percentage \\
\hline \multirow{3}{*}{ France } & Intra-Firms & 6.51 & Intra-Firms & 2.48 \\
\hline & Other Professional & 8.02 & Financial & 2.32 \\
\hline & Computer & 3.69 & Computer & 3.22 \\
\hline \multirow{3}{*}{ Germany } & Intra-Firms & 4.58 & Intra-Firms & 2.86 \\
\hline & Telecommunication & 7.21 & Computer & 4.28 \\
\hline & Computer & 4.88 & Telecommunication & 5.61 \\
\hline \multirow{3}{*}{ India } & Computer & 4.25 & & \\
\hline & Intra-Firms & 1.73 & & \\
\hline & Other Professional & 5.23 & & \\
\hline \multirow{3}{*}{ Ireland } & Computer & 6.18 & Intra-Firms & 3.23 \\
\hline & Advertising & 10.15 & Financial & 4.03 \\
\hline & Telecommunication & 2.51 & Computer & 5.91 \\
\hline \multirow{3}{*}{ Italy } & Intra-Firms & 1.55 & Intra-Firms & 1.03 \\
\hline & Telecommunication & 2.36 & Telecommunication & 2.27 \\
\hline & Construction in the UK & 10.31 & Financial & 0.71 \\
\hline \multirow{3}{*}{ Japan } & Royalty and License & 11.3 & $\mathrm{R} \& \mathrm{D}$ & 4.68 \\
\hline & Intra-Firms & 1.22 & Financial & 0.98 \\
\hline & Financial & 4.32 & Royalty and License & 1.64 \\
\hline \multirow{3}{*}{ Netherlands } & Intra-Firms & 1.69 & Intra-Firms & 6.01 \\
\hline & Use of Franchise & 5.32 & Financial & 3.01 \\
\hline & Computer & 1.54 & Computer & 2.24 \\
\hline \multirow{3}{*}{ Sweden } & R\&D & 9.96 & & \\
\hline & Intra-Firms & 1.02 & & \\
\hline & Computer & 1.35 & & \\
\hline \multirow{3}{*}{ Switzerland } & Intra-Firms & 1.76 & Intra-Firms & 3.98 \\
\hline & Computer & 1.58 & $\mathrm{R} \& \mathrm{D}$ & 6.82 \\
\hline & Royalty and License & 1.62 & Royalty and License & 4.94 \\
\hline \multirow{3}{*}{ United States } & Intra-Firms & 11.62 & Intra-Firms & 13.11 \\
\hline & Royalty and License & 19.49 & Financial & 12.6 \\
\hline & $\mathrm{R} \& \mathrm{D}$ & 18.1 & $R \& D$ & 15.69 \\
\hline \multirow{3}{*}{ China } & & & Intra-Firms & 0.54 \\
\hline & Intra-Firms & 0.29 & Merchanting & 1.66 \\
\hline & Other Trade Related & 3.07 & Royalty and License & 0.87 \\
\hline \multirow{3}{*}{ Saudi Arabia } & & & Other Transaction & 25.95 \\
\hline & & & Engineering & 5.12 \\
\hline & & & Financial & 0.73 \\
\hline \multirow{3}{*}{ Channel islands } & & & Financial & 4.7 \\
\hline & & & Intra-Firms & 1.02 \\
\hline & & & Legal & 3.19 \\
\hline
\end{tabular}

Source: ITIS (ONS). Column "Percentage" refers to the share of imports (export) of service $i$ from (to) country $x$ on the overall imports (exports) of service $i$. 
Table A.3: SIC2007 and ITIS conversion table

\begin{tabular}{|c|c|c|}
\hline Sic (4 digit specification) & Service ITIS classification & Services Description \\
\hline $0161,0162,0163,0164,0170,0240$ & 1 & Agricultural, Forestry and Fishing \\
\hline 0910, 0990 & 2 & Mining and Oil Gas Extraction \\
\hline $\begin{array}{l}3600,3700,3811,3812,3821,3822,3831 \text {, } \\
3832,3900\end{array}$ & 3 & Waste Treatment and De-Pollution \\
\hline $\begin{array}{l}3311,3312,3313,3314,3315,3316,3317 \\
3319,3320,6920,7022,9511,9512,9521, \\
9522,9523,9524,9525,4520,4540,9529\end{array}$ & 5 & Maintenance and Repair \\
\hline NA & 4 & $\begin{array}{l}\text { Manufacturing Services on Goods Owned } \\
\text { by Others }\end{array}$ \\
\hline $7311,7312,7320$ & 7 & $\begin{array}{l}\text { Advertising, Market Research and Public } \\
\text { Opinion Polling }\end{array}$ \\
\hline 7010 & 8 & $\begin{array}{l}\text { Business Management and Management } \\
\text { Consulting }\end{array}$ \\
\hline 7021 & 9 & Public Relations \\
\hline $7810,7820,7830$ & 10 & Recruitment \\
\hline 6910 & 11 & Legal \\
\hline $\begin{array}{l}7711,7712,7721,7722,7729,7731,7732, \\
7733,7734,7735,7739\end{array}$ & 12 & Operating Leasing \\
\hline 5229 & 13 & Procurement services \\
\hline $6810,6820,6831,6832$ & 14 & Property Management \\
\hline $741,074,207,430$ & 15 & Other Business and Professional \\
\hline $721,172,197,220$ & 16 & Provision of R\&D services \\
\hline NA & 17 & $\begin{array}{l}\text { Provision of Product Development and } \\
\text { Testing Activities }\end{array}$ \\
\hline 7740 & 18 & Royalties and Licensing \\
\hline $53,105,320$ & 21 & Postal and Courier \\
\hline $6110,6120,6130,6190$ & 22 & Telecommunication \\
\hline $6201,6202,6203,6209$ & 23 & Computer \\
\hline $5811,5812,5813,5814,5819,5821,5829$ & 24 & Publishing \\
\hline 6391 & 25 & News Agency \\
\hline
\end{tabular}




\begin{tabular}{|c|c|c|}
\hline Sic (4 digit specification) & Service ITIS classification & Services Description \\
\hline $6311,6312,6399$ & 26 & Information \\
\hline $\begin{array}{l}\text { 4110, 4120, 4311, 4312, 4313, 4321, 4322, } \\
4329,4331,4332,4333,4334,4339,4391, \\
4399\end{array}$ & 27,28 & Construction \\
\hline $6411,6419,6420,6430,6490,6492,6499$ & 29 & Financial \\
\hline $651,165,126,520$ & $30-35$ & Insurance \\
\hline $6611,6612,6619,6621,6622,6629,6630$ & 36 & Auxiliary \\
\hline 6530 & 37 & Pension \\
\hline NA & 39 & Standardised Guarantee Services Claims \\
\hline NA & 40 & $\begin{array}{l}\text { Standardised Guarantee Service Premi- } \\
\text { ums }\end{array}$ \\
\hline $\begin{array}{l}4531,4532,4611,4612,4613,4614,4615, \\
4616,4617,4618,4619,4621,4622,4623, \\
4624,4630,4632,4633,4634,4635,4636, \\
4637,4638,4639,4641,4642,4643,4644, \\
4645,4646,4647,4648,4649,4651,4652, \\
4661,4662,4663,4664,4665,4666,4669, \\
4671,4672,4673,4674,4675,4676,4677, \\
4690,4711,4719,4721,4722,4723,4724, \\
4725,4726,4729,4730,4741,4742,4743, \\
4751,4752,4753,4754,4759,4761,4762, \\
4763,4764,4765,4771,4772,4773,4774, \\
4775,4776,4777,4778,4779,4781,4782, \\
4789,4791,4799\end{array}$ & 41,42 & Merchanting and other trade-related \\
\hline $5911,5912,5913,5914,5920$ & 43 & Audio-Visual and Related \\
\hline $8610,8621,8622,8623,8690$ & 44 & Health \\
\hline $\begin{array}{l}8510,8520,8531,8532,8541,8542,8551, \\
8552,8553,8559,8560\end{array}$ & 45 & Training and Educational \\
\hline $\begin{array}{l}\text { 9001, 9002, 9003, 9004, 9101, 9103, 9104, } \\
9200,9311,9312,9313,9319,9321,9329\end{array}$ & 46 & Heritage and Recreational \\
\hline $9601,9602,9603,9604,9609,9700$ & 47 & Social, Domestic and Other Personal \\
\hline 7111 & 48 & Architectural \\
\hline $\begin{array}{l}7112,4211,4212,4213,4221,4222,4291, \\
4299\end{array}$ & 49 & Engineering \\
\hline 7120,7490 & 50 & $\begin{array}{l}\text { Scientific and Other Technical (Including } \\
\text { Surveying) }\end{array}$ \\
\hline NA & 51 & $\begin{array}{l}\text { Transactions Between Related Businesses } \\
\text { Not Included Elsewhere }\end{array}$ \\
\hline NA & 52 & Other Trade in Services \\
\hline
\end{tabular}

Source: Author's conversion. The table indicates the correspondences between the ONS SIC2007 4 digit codes and the corresponding services categories used in the analysis. 
Table A.4: Services Offshoring

\begin{tabular}{llll}
\hline $\begin{array}{l}\text { Share of Imports } \\
\text { on Total Trade }\end{array}$ & $\begin{array}{l}\text { Share of Exports } \\
\text { on Total Trade }\end{array}$ & $\begin{array}{l}\text { Share of Broad } \\
\text { Offshoring on To- } \\
\text { tal Imports }\end{array}$ & $\begin{array}{l}\text { Share of Narrow } \\
\text { Offhsoring on To- } \\
\text { tal Imports }\end{array}$ \\
\hline
\end{tabular}

\section{Overall}

Mean

0.64

0.36

0.18

0.06

St. Dev.

0.44

0.44

0.32

0.22

$\mathrm{N}$

420,515

420,515

351,618

351,618

Manufacturing,

Low Tech

$\begin{array}{lcc}\text { Mean } & 0.70 & 0.30 \\ \text { St. Dev. } & 0.41 & 0.41 \\ \text { N } & 99,607 & 99,607\end{array}$

Manufacturing,

High Tech

Mean

$\begin{array}{ll}0.70 & 0.30\end{array}$

St. Dev.

0.42

0.42

$\mathrm{N}$

27,109

27,109

Services

Mean

0.58

0.42

St. Dev.

0.45

0.44

$\mathrm{N}$

240,248

240,248

Source: ITIS. The first two columns indicate the average share of imports and exports of each services and each firm on total trade in services flows. Second two columns indicate the share of Broad and Narrow Offshoring for each service and each firm on total imports of services. The macro sectors are defined as: Low Tech Manufacturing SIC07 10-25, 32-35; High Tech Manufacturing SIC07 26-31; Services SIC07 45-98. 
Table A.5: Employment, average wage and productivity elasticity to services offshoring

\begin{tabular}{llllllll}
$(1)$ & $(2)$ & $(3)$ & $(4)$ & $(5)$ & $(6)$ & $(7)$ & $(8)$ \\
OLS & IV & OLS & IV & OLS & IV & OLS & IV \\
\hline
\end{tabular}

\section{A. Employment}

Broad Offshoring

$0.07^{* * *} \quad 1.12^{* * *} \quad 0.07^{* * *} \quad 0.49^{* * *} \quad 0.11^{* * *} \quad 0.31^{* * *}$

$(0.01)$

$(0.23)$

$(0.01)$

$(0.11)$

$(0.02)$

$(0.10)$

Manufacturing

$\begin{array}{llll}0.03^{* * *} & -0.19 & 0.06^{* * *} & 0.46^{* * *} \\ (0.01) & (0.25) & (0.02) & (0.18)\end{array}$

\# Broad Offshoring

$(0.01)$

$(0.25)$

$(0.02)$

$(0.18)$

Narrow Offshoring

\section{B. Average Wage}

Broad Offshoring

$\begin{array}{llllll}0.01^{* * *} & 0.03^{* * *} & 0.03^{* * *} & 0.09^{* * *} & 0.04^{* * *} & 0.14\end{array}$

$\begin{array}{llllll}(0.00) & (0.01) & (0.00) & (0.02) & (0.01) & (0.14)\end{array}$

$0.08^{* * *} 0.22^{* *}$

$(0.01) \quad(0.09)$

Manufacturing

\# Broad Offshoring

$\begin{array}{llll}-0.01^{* *} & -0.00 & -0.01 & -0.03\end{array}$

$\begin{array}{llll}(0.00) & (0.01) \quad(0.01) \quad(0.03)\end{array}$

Narrow Offshoring

$0.03^{* * *} \quad 0.19$

(0.01) (0.12)

\section{Productivity}

Broad Offshoring

Manufacturing

\# Broad Offshoring

Narrow Offshoring

$\begin{array}{llllll}0.02^{* * *} & 0.17^{* *} & 0.04^{* * *} & 0.09^{* * *} & 0.06^{* * *} & 0.11 \\ (0.01) & (0.08) & (0.01) & (0.03) & (0.01) & (0.13) \\ & & & & & \\ -0.02^{* *} & -0.10 & -0.00 & 0.02 & & \\ (0.01) & (0.07) & (0.01) & (0.06) & & \end{array}$

$0.06^{* * *} \quad 0.11$

$(0.01) \quad(0.14)$

\section{First Stage}

Offshoring Other Countries

\begin{tabular}{|c|c|c|c|c|c|c|c|c|}
\hline $\begin{array}{l}\text { Manufacturing \# } \\
\text { Offshoring Other Countries }\end{array}$ & & $\begin{array}{l}0.09^{* * *} \\
(0.03)\end{array}$ & & $\begin{array}{l}0.20^{* * *} \\
(0.06)\end{array}$ & & & & \\
\hline Ftest & & 43.79 & & 13.42 & & 8.23 & & 27.84 \\
\hline Control Variables & $\sqrt{ }$ & $\sqrt{ }$ & $\sqrt{ }$ & $\sqrt{ }$ & $\sqrt{ }$ & $\sqrt{ }$ & $\sqrt{ }$ & $\sqrt{ }$ \\
\hline Local Area \# Year & $\sqrt{ }$ & $\sqrt{ }$ & $\sqrt{ }$ & $\sqrt{ }$ & $\sqrt{ }$ & $\sqrt{ }$ & $\sqrt{ }$ & $\sqrt{ }$ \\
\hline Sector \# Year & $\sqrt{ }$ & $\sqrt{ }$ & $\sqrt{ }$ & $\sqrt{ }$ & $\sqrt{ }$ & $\sqrt{ }$ & $\sqrt{ }$ & $\sqrt{ }$ \\
\hline $\mathrm{N}$ & 386,769 & 386,769 & 18,460 & 18,460 & 1,841 & 1,841 & 1,841 & 1,841 \\
\hline
\end{tabular}

Source: Data obtained combining ARD/ABS, ITIS datasets (ONS). Standard errors in parentheses are clustered at the sector and local area level. Dependent variable: Logarithm of Employment (panel A), Logarithm of Average Wage (Panel B), Logarithm of Productivity (Panel C). The base for the interaction variable is the service industry. Control variables: log of share of British owned firms in a sector local area and the log of expenditure in computer service, lagged 1 year. Columns 1-2 include the all the local labour markets of the dataset. Columns 3-4 include only those local labour markets involved in services offshoring. Columns 5-8 are limited to those local labour markets involved both in narrow and broad offshoring. $(p<0.10),{ }^{* *}(p<0.05),{ }^{* * *}(p<0.01)$ 
Table A.6: Employment and Average Wage elasticity to services offshoring by quantiles

\begin{tabular}{|c|c|c|c|c|c|c|c|c|}
\hline & \multicolumn{4}{|c|}{ Employment } & \multicolumn{4}{|c|}{ Average Wage } \\
\hline & $(1)$ & $(2)$ & $(3)$ & (4) & $(5)$ & (6) & $(7)$ & (8) \\
\hline & OLS & IV & OLS & IV & OLS & IV & OLS & IV \\
\hline $\begin{array}{l}\text { 10th quantile \# } \\
\text { Broad Offshoring }\end{array}$ & $\begin{array}{c}-0.189 * * * \\
(0.010)\end{array}$ & $\begin{array}{c}0.084 \\
(0.059)\end{array}$ & $\begin{array}{c}-0.177^{* * *} \\
(0.012)\end{array}$ & $\begin{array}{c}0.102^{* *} \\
(0.044)\end{array}$ & $\begin{array}{c}-0.057^{* * *} \\
(0.004)\end{array}$ & $\begin{array}{c}-0.058^{* * *} \\
(0.013)\end{array}$ & $\begin{array}{c}-0.055^{* * *} \\
(0.004)\end{array}$ & $\begin{array}{c}-0.045^{* * *} \\
(0.008)\end{array}$ \\
\hline $\begin{array}{l}\text { 25th quantile \# } \\
\text { Broad Offshoring }\end{array}$ & $\begin{array}{c}-0.098 * * * \\
(0.007)\end{array}$ & $\begin{array}{c}0.1868^{* * *} \\
\quad(0.059)\end{array}$ & $\begin{array}{c}-0.085^{* * *} \\
(0.011)\end{array}$ & $\begin{array}{c}0.206^{* * *} \\
(0.044)\end{array}$ & $\begin{array}{c}-0.024^{* * *} \\
(0.002)\end{array}$ & $\begin{array}{l}-0.022^{*} \\
(0.012)\end{array}$ & $\begin{array}{c}-0.022^{* * *} \\
(0.002)\end{array}$ & $\begin{array}{l}-0.008 \\
(0.007)\end{array}$ \\
\hline $\begin{array}{l}\text { 50th quantile \# } \\
\text { Broad Offshoring }\end{array}$ & $\begin{array}{c}0.018^{* * *} \\
(0.006)\end{array}$ & $\begin{array}{c}0.317^{* * * *} \\
(0.059)\end{array}$ & $\begin{array}{c}0.033^{* * *} \\
(0.009)\end{array}$ & $\begin{array}{c}0.337^{* * * *} \\
(0.045)\end{array}$ & $\begin{array}{c}0.006^{* * *} \\
(0.001)\end{array}$ & $\begin{array}{c}0.012 \\
(0.012)\end{array}$ & $\begin{array}{c}0.008^{* * * *} \\
(0.002)\end{array}$ & $\begin{array}{c}0.026^{* * *} \\
(0.007)\end{array}$ \\
\hline $\begin{array}{l}\text { 75th quantile \# } \\
\text { Broad Offshoring }\end{array}$ & $\begin{array}{c}0.142^{* * *} \\
(0.008)\end{array}$ & $\begin{array}{c}0.454^{* * * *} \\
(0.060)\end{array}$ & $\begin{array}{c}0.157^{* * * *} \\
(0.010)\end{array}$ & $\begin{array}{c}0.476^{* * *} \\
(0.048)\end{array}$ & $\begin{array}{c}0.035^{* * *} \\
(0.002)\end{array}$ & $\begin{array}{c}0.044^{* * *} \\
(0.012)\end{array}$ & $\begin{array}{c}0.037^{* * * *} \\
(0.002)\end{array}$ & $\begin{array}{c}0.059^{* * *} \\
(0.008)\end{array}$ \\
\hline $\begin{array}{l}\text { 90th quantile \# } \\
\text { Broad Offshoring }\end{array}$ & $\begin{array}{c}0.255^{* * *} \\
(0.009)\end{array}$ & $\begin{array}{c}0.577^{* * * *} \\
(0.063)\end{array}$ & $\begin{array}{c}0.271^{* * *} \\
(0.010)\end{array}$ & $\begin{array}{c}0.599 * * * \\
(0.050)\end{array}$ & $\begin{array}{c}0.062^{* * *} \\
(0.004)\end{array}$ & $\begin{array}{c}0.075^{* * *} \\
(0.013)\end{array}$ & $\begin{array}{c}0.065^{* * *} \\
(0.004)\end{array}$ & $\begin{array}{c}0.089^{* * *} \\
(0.009)\end{array}$ \\
\hline Local Area \# Year & $\sqrt{ }$ & $\sqrt{ }$ & $\sqrt{ }$ & $\sqrt{ }$ & $\sqrt{ }$ & $\sqrt{ }$ & $\sqrt{ }$ & $\sqrt{ }$ \\
\hline Sector \# Year & $\sqrt{ }$ & $\sqrt{ }$ & $\sqrt{ }$ & $\sqrt{ }$ & $\sqrt{ }$ & $\sqrt{ }$ & $\sqrt{ }$ & $\sqrt{ }$ \\
\hline Control Variables & $\sqrt{ }$ & $\sqrt{ }$ & $\sqrt{ }$ & $\sqrt{ }$ & $\sqrt{ }$ & $\sqrt{ }$ & $\sqrt{ }$ & $\sqrt{ }$ \\
\hline $\mathrm{N}$ & 55,975 & 55,975 & 55,975 & 55,975 & 55,975 & 55,975 & 55,975 & 55,975 \\
\hline
\end{tabular}

Source: Data obtained combining ARD/ABS, ITIS datasets (ONS). Standard errors in parentheses are clustered at the sector and local area level. Dependent variable: Logarithm of Employment, Logarithm of Average Wage. Control variables: $\log$ of share of British owned firms in a sector local area and the log of expenditure in computer service, lagged 1 year. ${ }^{*}(p<0.10),{ }^{* *}(p<0.05),{ }^{* * *}(p<0.01)$ 
Table A.7: Employment and average wage and elasticity to services offshoring, firm level analysis

\begin{tabular}{llllllll}
\hline$(1)$ & $(2)$ & $(3)$ & $(4)$ & $(5)$ & $(6)$ & $(7)$ & $(8)$
\end{tabular}

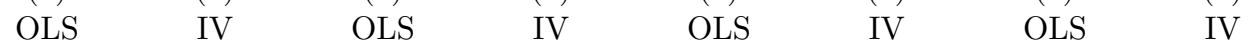

\section{A. Employment}

Broad Offshoring

$\begin{array}{cc}0.01^{* * *} & 0.30^{* * *} \\ (0.00) & (0.05)\end{array}$

Non Importer \#

Broad Offshoring

Narrow Offshoring

$\begin{array}{cc}0.01^{* * *} & 0.01^{* * *} \\ (0.00) & (0.00)\end{array}$

Non Importer \#

Narrow Offshoring

Other Offshoring

Non Importer \#

Input Offshoring

\section{B. Average Wage}

Broad Offshoring

$\begin{array}{cc}0.00 & 0.02 \\ (0.00) & (0.00)\end{array}$

Non Importer \#

Broad Offshoring

Narrow Offshoring

$\begin{array}{cc}0.00 & 0.00^{*} \\ (0.00) & (0.00)\end{array}$

$$
\begin{array}{cc}
0.04^{* * *} & 0.09^{* * *} \\
(0.00) & (0.01) \\
& \\
-0.04^{* * *} & -0.08^{* * *} \\
(0.00) & (0.01)
\end{array}
$$

$\begin{array}{cc}0.09^{* * *} & -4.35 \\ (0.01) & (5.86) \\ -0.08^{* * *} & 4.31 \\ (0.01) & (15.89) \\ 0.05^{* * *} & 12.46 \\ (0.00) & (16.33) \\ -0.05^{* * *} & -12.24 \\ (0.00) & (16.37)\end{array}$

(0.00) (16.37)

Non Importer \#

Narrow Offshoring

Input Offshoring

$\begin{array}{cc}0.04^{* * *} & -1.35 \\ (0.00) & (1.90) \\ & \\ -0.04^{* * *} & 1.37 \\ (0.00) & (1.91) \\ & \\ 0.03^{* * *} & 3.93 \\ (0.00) & (5.30)\end{array}$

Non Importer \#

Input Offshoring

\begin{tabular}{lcccccccc}
\hline Local Area \# Year & $\sqrt{ }$ & $\sqrt{ }$ & $\sqrt{ }$ & $\sqrt{ }$ & $\sqrt{ }$ & $\sqrt{ }$ & $\sqrt{ }$ & $\sqrt{ }$ \\
\hline Sector \# Year & $\sqrt{ }$ & $\sqrt{ }$ & $\sqrt{ }$ & $\sqrt{ }$ & $\sqrt{ }$ & $\sqrt{ }$ & $\sqrt{ }$ & $\sqrt{ }$ \\
\hline Control Variables & $\sqrt{ }$ & $\sqrt{ }$ & $\sqrt{ }$ & $\sqrt{ }$ & $\sqrt{ }$ & $\sqrt{ }$ & $\sqrt{ }$ & $\sqrt{ }$ \\
\hline Observations & $2,913,555$ & $2,913,555$ & $2,913,555$ & $2,913,555$ & $2,913,555$ & $2,913,555$ & $2,913,555$ & $2,913,555$ \\
\hline \hline
\end{tabular}

Source: Data obtained combining ARD/ABS, ITIS datasets (ONS). Standard errors in parentheses are robust. Dependent variable: Logarithm of Employment, Logarithm of Average Wage. The regression follows the specification as in table 1. Control variables: log of share of British owned firms in a sector-local area and the log of expenditure in computer service, lagged 1 year in a sector-local area. $(p<0.10),^{* *}(p<0.05),{ }^{* * *}(p<0.01)$ 
Table A.8: Employment and average wage elasticity to services offshoring, firm level analysis

\begin{tabular}{|c|c|c|c|c|c|}
\hline (1) & (2) & (3) & (4) & $(5)$ & (6) \\
\hline OLS & IV & OLS & IV & OLS & IV \\
\hline
\end{tabular}

\section{A. Employment}

Broad Offshoring

\begin{tabular}{|c|c|c|c|}
\hline $0.11^{* * *}$ & $0.43^{* * *}$ & $0.11^{* * *}$ & $0.02^{* * *}$ \\
\hline
\end{tabular}

$\begin{array}{lllll}(0.00) & (0.03) \quad(0.00) & (0.03) & (0.00) & (0.04)\end{array}$

Non Importer

\begin{tabular}{|c|c|c|}
\hline$-0.10^{* * *}-0.21^{* * *}$ & $-0.10^{* * *}$ & $-0.22^{* * *}$ \\
\hline
\end{tabular}

\# Broad Offshoring

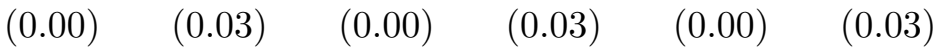

Same Group

$$
\begin{array}{cccc}
0.12^{* * *} & 0.12^{* * *} & -0.02^{* * *} & -0.02^{* * *} \\
(0.00) & (0.00) & (0.00) & (0.00)
\end{array}
$$

\section{B. Average Wage}

$\begin{array}{lcccccc}\text { Broad Offshoring } & 0.05^{* * *} & 0.18^{* * *} & 0.05^{* * *} & 0.18^{* * *} & 0.00^{* * *} & 0.16^{* * *} \\ & (0.00) & (0.01) & (0.00) & (0.01) & (0.00) & (0.02) \\ \text { Non Importer } & -0.05^{* * *} & -0.15^{* * *} & -0.05^{* * *} & -0.15^{* * *} & -0.00^{* * *} & -0.07^{* * *} \\ \text { \# Broad Offshoring } & (0.00) & (0.01) & (0.00) & (0.01) & (0.00) & (0.01) \\ & & & & & & \\ \text { Same Group } & & & -0.00 & -0.00 & 0.02^{* * *} & 0.02^{* * *} \\ & & & (0.00) & (0.00) & (0.00) & (0.00)\end{array}$

\begin{tabular}{lcccccc}
\hline Local Area \# Year & $\sqrt{ }$ & $\sqrt{ }$ & $\sqrt{ }$ & $\sqrt{ }$ & $\sqrt{ }$ & $\sqrt{ }$ \\
\hline Sector \# Year & $\sqrt{ }$ & $\sqrt{ }$ & $\sqrt{ }$ & $\sqrt{ }$ & $\sqrt{ }$ & $\sqrt{ }$ \\
\hline Firm Fixed effects & & & & & $\sqrt{ }$ & $\sqrt{ }$ \\
\hline $\begin{array}{l}\text { Sector local area Control } \\
\text { Variables }\end{array}$ & $\sqrt{ }$ & $\sqrt{ }$ & $\sqrt{ }$ & $\sqrt{ }$ & $\sqrt{ }$ & $\sqrt{ }$ \\
\hline Firm Control Variable & & & $\sqrt{ }$ & $\sqrt{ }$ & $\sqrt{ }$ & $\sqrt{ }$ \\
\hline Observations & 627,519 & 627,519 & 627,519 & 627,519 & 627,519 & 627,519 \\
\hline \hline
\end{tabular}

Source: Data obtained combining ARD/ABS, ITIS datasets (ONS). Standard errors in parentheses are robust. Dependent variable: Logarithm of Employment (Panel A), Logarithm of Average Wage (Panel B). The base for the interaction variable "Non Importer \# Broad Offshoring" is importer status. "Same Group" is a dummy variable taking value 1 if a firm belongs to the same enterprise group of an importing firm. Sector local area control variables: log of share of British owned firms in a sector local area and the log of expenditure in computer service, lagged 1 year. Firm control variables: foreign ownership of a firm. ${ }^{*}(p<0.10),{ }^{* *}(p<0.05),{ }^{* * *}(p<0.01)$ 
Table A.9: Employment and average wage elasticity to services offshoring, firm level analysis

\begin{tabular}{cccccc}
\hline$(1)$ & $(2)$ & $(3)$ & $(4)$ & $(5)$ & $(6)$ \\
OLS & IV & OLS & IV & OLS & IV \\
\hline
\end{tabular}

\section{A. Employment}

Narrow Offshoring

$\begin{array}{cccccc}0.07^{* * *} & 1.40 & 0.07^{* * *} & 1.48 & 0.02^{* * *} & 0.11^{*} \\ (0.01) & (0.99) & (0.01) & (1.05) & (0.01) & (0.06) \\ & & & & & \\ -0.06^{* * *} & -1.46 & -0.06^{* * *} & -1.54 & -0.02^{* * *} & -0.12^{* * *} \\ (0.01) & (1.00) & (0.01) & (1.05) & (0.01) & (0.06) \\ 0.08^{* * *} & -3.20 & 0.08^{* * *} & -3.40 & 0.01^{* * *} & -0.26 \\ (0.01) & (2.50) & (0.01) & (2.65) & (0.00) & (0.20) \\ -0.08^{* * *} & 3.43 & -0.08^{* * *} & 3.64 & -0.01^{* * *} & 0.32^{*} \\ (0.01) & (2.50) & (0.01) & (2.64) & (0.00) & (0.19) \\ & & & & & \\ & & 0.12^{* * *} & 0.12^{* * *} & -0.02^{* * *} & -0.02^{* * *} \\ & & (0.00) & (0.01) & (0.00) & (0.00)\end{array}$

\section{B. Average Wage}

Narrow Offshoring

$\begin{array}{cccccc}0.03^{* * *} & 0.60 & 0.03^{* *} & 0.60 & 0.00 & -0.00 \\ (0.00) & (0.37) & (0.00) & (0.38) & (0.00) & (0.03)\end{array}$

Non Importer

$-0.03^{* * *}$

$-0.60-0.03^{* *}$

$-0.60$

$-0.00$

\# Narrow Offshoring

(0.00)

$(0.38)$

(0.00)

(0.38)

(0.00)

Input Offshoring

$0.04^{* * *}$

$-1.30 \quad 0.04^{* * *}$

$-1.30$

0.00

0.05

(0.00)

(0.94)

(0.00)

(0.95) (0.00)

Non Importer

$$
-0.04^{* * * *}
$$

$1.31-0.04^{* * *}$

1.31

$-0.00$

\# Input Offshoring

(0.00)

(0.94)

(0.00)

(0.95)

$(0.00)$

Same group

$\begin{array}{cccc}-0.00 & 0.00 & 0.02^{* * *} & 0.02^{* * *} \\ (0.00) & (0.00) & (0.00) & (0.00)\end{array}$

\begin{tabular}{lcccccc}
\hline Local Area \# Year & $\sqrt{ }$ & $\sqrt{ }$ & $\sqrt{ }$ & $\sqrt{ }$ & $\sqrt{ }$ & $\sqrt{ }$ \\
\hline Sector \# Year & $\sqrt{ }$ & $\sqrt{ }$ & $\sqrt{ }$ & $\sqrt{ }$ & $\sqrt{ }$ & $\sqrt{ }$ \\
\hline Firm Fixed effects & & & $\sqrt{ }$ & $\sqrt{ }$ & $\sqrt{ }$ & $\sqrt{ }$ \\
\hline $\begin{array}{l}\text { Sector local area Control } \\
\text { Variables }\end{array}$ & $\sqrt{ }$ & $\sqrt{ }$ & $\sqrt{ }$ & $\sqrt{ }$ & $\sqrt{ }$ & $\sqrt{ }$ \\
\hline Firm Control Variable & & & & & & \\
\hline Observations & 627,519 & 627,519 & 627,519 & 627,519 & 627,519 & 627,519 \\
\hline \hline
\end{tabular}

Source: Data obtained combining ARD/ABS, ITIS datasets (ONS). Standard errors in parentheses are robust. Dependent variable: Logarithm of Employment (Panel A), Logarithm of Average Wage (Panel B). The base for the interaction variable is importer status. "Same Group" is a dummy variable taking value 1 if a firm belongs to the same enterprise group of an importing firm. Sector local area control variables: log of share of British owned firms in a sector local area and the log of expenditure in computer service, lagged 1 year. Firm control variables: foreign ownership of a firm. ${ }^{*}(p<0.10),{ }^{* *}(p<0.05),{ }^{* * *}(p<0.01)$ 
Table A.10: Sector- Local Area Offshoring, Employment and Hourly Pay(QLFS Measure)

\begin{tabular}{|c|c|c|c|c|}
\hline & $\begin{array}{c}(1) \\
\text { OLS }\end{array}$ & $\begin{array}{l}\text { (2) } \\
\text { IV }\end{array}$ & $\begin{array}{c}(3) \\
\text { OLS }\end{array}$ & $\begin{array}{l}\text { (4) } \\
\text { IV }\end{array}$ \\
\hline \multicolumn{5}{|l|}{ A. Employment } \\
\hline Broad Offshoring & $\begin{array}{c}0.06^{* * *} \\
(0.01)\end{array}$ & $\begin{array}{c}0.32^{* * *} \\
(0.04)\end{array}$ & $\begin{array}{c}0.04^{* * *} \\
(0.01)\end{array}$ & $\begin{array}{c}0.33^{\text {*** }} \\
(0.06)\end{array}$ \\
\hline \multicolumn{5}{|l|}{ B. Hourly Pay } \\
\hline \multirow[t]{2}{*}{ Broad Offshoring } & $\begin{array}{l}0.01^{*} \\
(0.00)\end{array}$ & $\begin{array}{l}0.03^{* *} \\
(0.01)\end{array}$ & $\begin{array}{c}0.00 \\
(0.00)\end{array}$ & $\begin{array}{l}0.03^{*} \\
(0.01)\end{array}$ \\
\hline & \multicolumn{4}{|c|}{ First Stage } \\
\hline Imports Other High Income countries & & $\begin{array}{c}0,63^{* * *} \\
(0.11)\end{array}$ & & $\begin{array}{c}0,47^{* * *} \\
(0.11)\end{array}$ \\
\hline F-test & & 35.66 & & 42.81 \\
\hline $\begin{array}{l}\text { Local Area\#Time FE } \\
\text { Sector\#Time FE } \\
\text { Control Variable }\end{array}$ & $\begin{array}{l}\sqrt{ } \\
\sqrt{ }\end{array}$ & $\begin{array}{l}\sqrt{ } \\
\sqrt{ } \\
\sqrt{ }\end{array}$ & $\begin{array}{l}\sqrt{ } \\
\sqrt{ }\end{array}$ & $\begin{array}{l}\sqrt{ } \\
\sqrt{ } \\
\sqrt{ }\end{array}$ \\
\hline$N$ & 6,487 & 6,487 & 6,487 & 6,487 \\
\hline
\end{tabular}

Source: Data obtained combining QLFS, ARD/ABS, ITIS datasets (ONS). Standard errors in parentheses are robust. Dependent variable: Logarithm of Employment, Logarithm of average hourly pay. Control variables: log of share of British owned firms in a sector local area and the log of expenditure in computer service, lagged 1 year. ${ }^{*}(p<0.10),{ }^{* *}(p<0.05)$, *** $(p<0.01)$ 


\section{B. Data Construction}

The UK combines different sources of information to produce its official statistics on trade in services. Amongst those, the International Trade in Services Survey (ONS, 2017) provides, for a selection of firms in the UK, detailed information on trade in services flows. Data include the type, value and partner country of traded services on a yearly and quarterly basis and covers more than half of the country's imports and exports. Unfortunately, passenger transport, higher education, financial and banking sectors are not included in ITIS, and data sources that do contain those informations are not accessible to researchers. Specifically, information on travel passenger transport is collected by the International Passenger Survey; higher education by the Higher Education Statistic Agency and the IPS; financial and banking services that are not included in the ITIS are collected by the Bank of England and ONS's security dealers' survey (ONS, 2013).

Differently from other services trade datasets, ITIS distinguishes between a relatively large number of services types, that is, 52 categories equivalent to the UN EBOPS (Extended Balance of Payment Services) services industry classification. ${ }^{35}$ The dataset represents the most complete set of information at the firm level available to researchers.

The selection of firms sampled for the ITIS survey consists of three steps. First, all firms in the UK with a VAT or PAYE schemes are included in the Inter-departmental Business Register (IDBR), which covers approximately 2.1 million enterprises. The universe of large firms (more than $250 \mathrm{em}$ ployees) and a representative sample of medium and small firms in Great Britain are then selected to be part of the Annual Respondents Database (ONS, 2011). ${ }^{36}$ Beginning from 2007, ARD has been partitioned into the Annual Business Survey (ONS, 2016), containing information on firms' financial activities, and the Business Register and Employment Survey (BRES), containing information on firms' employment. The datasets distinguish, for each firm, between reporting units (the plant receiving the questionnaire and providing information for the whole firm) and local units (plants not directly surveyed but part of the same firm). For single plant firms, the reporting unit and the local unit coincide. The questionnaires sent to firms' reporting units in the ARD/ABS are used to produce national statistics on the UK economy. Among other information, firms have to specify whether they have been involved in services trade in the last 12 months; firms that positively answer to the question are then selected in the ITIS sample.

Through firms' unique identification number, I merge ARD/ABS reporting unit with the ITIS. ${ }^{37}$ Further, for the purpose of the analysis, I have merged together the sample selected in the ABS/ARD

\footnotetext{
${ }^{35}$ See EBOPS for a complete list of the services included in the UN EBOPS.

${ }^{36}$ For an extended description of the ARD dataset see Criscuolo et al. (2004), which firstly provides an extensive description on the sample procedure and the information contained in the ARD.

${ }^{37}$ Information contained in the BRES and ABS are collected separately and the samples selected independently for each dataset. Therefore and for the purpose of the present study, I have excluded the BRES from the analysis.
} 
with their local units (i.e. plants). The additional dataset provides information on employment, turnover, sector and geographic location as contained in the IDBR of all local units of firms selected in the ARD/ABS. This enables to locate each firm's plants throughout the UK and aggregate measures are computed using these information. However, the ITIS dataset does not identify which plant within any firm is importing services. Following the recommendation of the data provider, for multi-plants firms, I identify as importer the plant with the highest number of employees. ${ }^{38}$ The dataset further include sample weights as provided by the Office of National Statistics (ONS), such that representative statistics of the whole universe of firms in Great Britain can be derived.

The sample of analysis is restricted to the period 2000-2015 and exclude Northern Ireland as from 2001 information at the firm level are not available through ONS.

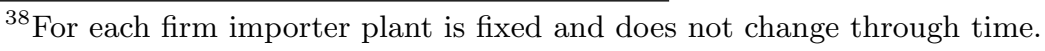




\section{Robustness and sensitivity checks}

Table C.1: Sensitivity Check

\begin{tabular}{|c|c|c|c|c|c|c|}
\hline & \multicolumn{3}{|c|}{ Employment } & \multicolumn{3}{|c|}{ Average Wage } \\
\hline & Coefficient & Observations & Fixed Effects & Coefficient & Observations & Fixed Effects \\
\hline \multicolumn{7}{|c|}{ I. Two digits sector specification } \\
\hline OLS & $\begin{array}{c}0.04^{* * *} \\
(0.01)\end{array}$ & 10,622 & Yes & $\begin{array}{c}0.004^{* * *} \\
(0.001)\end{array}$ & 10,622 & Yes \\
\hline IV & $\begin{array}{c}0.44^{* * *} \\
(0.08)\end{array}$ & 10,622 & Yes & $\begin{array}{c}0.01 \\
(0.01)\end{array}$ & 10,622 & Yes \\
\hline \multicolumn{7}{|c|}{ II. Excluding London } \\
\hline OLS & $\begin{array}{c}0.06^{* * *} \\
(0.01)\end{array}$ & 16,364 & Yes & $\begin{array}{c}0.02^{* * *} \\
(0.00)\end{array}$ & 16,364 & Yes \\
\hline IV & $\begin{array}{c}0.69^{* * *} \\
(0.16)\end{array}$ & 16,364 & Yes & $\begin{array}{l}0.08^{*} \\
(0.04)\end{array}$ & 16,364 & Yes \\
\hline \multicolumn{7}{|c|}{ III. Excluding Royalties and Licensing } \\
\hline OLS & $\begin{array}{c}0.07^{* * *} \\
(0.01)\end{array}$ & 17,844 & Yes & $\begin{array}{c}0.03^{* * *} \\
(0.00)\end{array}$ & 17,844 & Yes \\
\hline IV & $\begin{array}{c}0.51^{* * *} \\
(0.12)\end{array}$ & 17,844 & Yes & $\begin{array}{c}0.09^{* * * *} \\
(0.03)\end{array}$ & 17,844 & Yes \\
\hline \multicolumn{7}{|c|}{ IV. Excluding 2008} \\
\hline OLS & $\begin{array}{c}0.07^{* * *} \\
(0.01)\end{array}$ & 17,627 & Yes & $\begin{array}{c}0.03^{* * *} \\
(0.00)\end{array}$ & 17,627 & Yes \\
\hline IV & $\begin{array}{c}0.49^{* * *} \\
(0.11)\end{array}$ & 17,627 & Yes & $\begin{array}{c}0.09^{* * *} \\
(0.03)\end{array}$ & 17,627 & Yes \\
\hline \multicolumn{7}{|c|}{ V. Including Export of services } \\
\hline OLS & $\begin{array}{c}0.07^{* * *} \\
(0.01)\end{array}$ & 13,976 & Yes & $\begin{array}{c}0.02^{* * * *} \\
(0.01)\end{array}$ & 13,976 & Yes \\
\hline IV & $\begin{array}{c}0.86^{* * * *} \\
(0.16)\end{array}$ & 13,976 & Yes & $\begin{array}{c}0.07 \\
(0.05)\end{array}$ & 13,976 & Yes \\
\hline \multicolumn{7}{|c|}{ VI. One year lag } \\
\hline OLS & $\begin{array}{c}0.07^{* * *} \\
(0.01)\end{array}$ & 17,272 & Yes & $\begin{array}{c}0.02^{* * *} \\
(0.01)\end{array}$ & 17,272 & Yes \\
\hline IV & $\begin{array}{c}0.54^{* * *} \\
(0.10) \\
\end{array}$ & 17,272 & Yes & $\begin{array}{l}0.07^{*} \\
(0.04)\end{array}$ & 17,272 & Yes \\
\hline \multicolumn{7}{|c|}{ VII. Averaging the instrument } \\
\hline OLS & $\begin{array}{c}0.07^{* * *} \\
(0.01)\end{array}$ & 18,460 & Yes & $\begin{array}{c}0.03^{* * *} \\
(0.00)\end{array}$ & 18,460 & Yes \\
\hline IV & $\begin{array}{c}0.49^{* * *} \\
(0.11)\end{array}$ & 18,460 & Yes & $\begin{array}{c}0.09^{* * *} \\
(0.02)\end{array}$ & 18,460 & Yes \\
\hline \multicolumn{7}{|c|}{ VIII. Robust Standard Error } \\
\hline OLS & $\begin{array}{c}0.06^{* * *} \\
(0.00)\end{array}$ & 16,577 & Yes & $\begin{array}{c}0.03^{* * *} \\
(0.00)\end{array}$ & 16,577 & Yes \\
\hline IV & $\begin{array}{c}0.46^{* * * *} \\
(0.04)\end{array}$ & 16,577 & Yes & $\begin{array}{c}0.09^{* * *} \\
(0.02)\end{array}$ & 16,577 & Yes \\
\hline \multicolumn{7}{|c|}{ IX. Un-weighted measures } \\
\hline OLS & $\begin{array}{c}0.06^{* * *} \\
(0.01)\end{array}$ & 18,922 & Yes & $\begin{array}{c}0.03^{* * *} \\
(0.00)\end{array}$ & 18,922 & Yes \\
\hline IV & $\begin{array}{c}0.49^{* * *} \\
(0.11)\end{array}$ & 18,922 & Yes & $\begin{array}{c}0.07^{* * *} \\
(0.02)\end{array}$ & 18,922 & Yes \\
\hline
\end{tabular}

Source: Data obtained combining ARD/ABS, ITIS datasets (ONS). Standard errors in parentheses are clustered at the sector and local area level if not specified differently. Dependent variables: Logarithm of Employment and Logarithm of Average Wage. All regressions include a set of fixed effects (sector-year and local area-year) and control variables (log of share of British owned firms in a sector local area and the log of expenditure in computer service, lagged 1 year $) .^{*}(p<0.10),{ }^{* *}(p<0.05),{ }^{* * *}(p<0.01)$

A set of robustness checks on the sample of analysis is run in order to assess the robustness of the results (see table C.1). Firstly, the whole area of London (panel I) is excluded to rule out the possibility that the largest local area of the UK drives the results. As well, I exclude from the offshoring flows royalties and licensing trade (panel II) as part of the trade can be associated with balance sheet 
exercise. Subsequently, the year 2008 (panel III) is excluded as it coincides with the hit of the financial crisis in the UK. It might still be argued that the exports of services from a sector local area might bias the main findings. For this reason I repeat the analysis and control for sector local exports of services (panel IV). Further, the measure of sector local area import of services is lagged by one year to account for the different timing of the effects (panel V). On a more methodological aim, I repeat the analysis with robust standard errors instead of clustering it at the sector and local area level (panel VI)and without sample weights (panel VII). In none of the specification mentioned above results are significantly different from the main specification: both employment and average wages have positive elasticity to services offshoring.

To further control whether the results depend on the construction of services offshoring exposure measure, I use a different source of information to compute sector local area imports of intermediate services from abroad. In the main analysis, information on imports of services are obtained from the Inquiry in International Trade in Services (ITIS), which covers services trade flows above $£ 10,000$ disentangled between type of service and partner country. However, information on services imports can be obtained through the $\mathrm{ARD} / \mathrm{ABS}$ dataset, which contains values of services imports for each firm. Data from ARD/ABS are self-reported by the firms and include transition below the $£ 10,000$ value threshold such that when information are aggregated at the sector local area, imports of services are larger. Differently from the ITIS, the flows of services trade included in the ARD/ABS are not disentangled by country of origin nor by type of services imported. At the same time, since information on type of services traded are not required, imports might include financial, travel and education services, previously excluded from the analysis. The offshoring measure so constructed is similar to Broad offshoring in the main analysis.

I then implement the analysis as specified in section 3, using as a measure of services offshoring the imports of services obtained from the ARD/ABS. Findings are consistent with the rest of the analysis: elasticities of employment and of average wage to services imports are positive as shown in table C.2. Therefore, the estimation is robust to the changes in the explanatory variable and main findings proved: within a sector local area employment and average wage increase at the increase of imports of services. 
Table C.2: Employment, average wage and productivity elasticity to services offshoring, ARD/ABS measure

\begin{tabular}{|c|c|c|c|c|c|c|c|c|}
\hline & \multicolumn{4}{|c|}{ Employment } & \multicolumn{4}{|c|}{ Average Wage } \\
\hline & $(1)$ & $(2)$ & $(3)$ & (4) & $(5)$ & $(6)$ & $(7)$ & $(8)$ \\
\hline & OLS & IV & OLS & IV & OLS & IV & OLS & IV \\
\hline Broad Offshoring & $\begin{array}{c}0.12^{* * *} \\
(0.01)\end{array}$ & $\begin{array}{c}0.55^{* * *} \\
(0.03)\end{array}$ & $\begin{array}{c}0.10^{* * *} \\
(0.01)\end{array}$ & $\begin{array}{c}0.60^{* * *} \\
(0.04)\end{array}$ & $\begin{array}{c}0.03^{* * *} \\
(0.00)\end{array}$ & $\begin{array}{l}0.02^{*} \\
(0.01)\end{array}$ & $\begin{array}{c}0.03^{* * *} \\
(0.00)\end{array}$ & $\begin{array}{l}0.02^{*} \\
(0.01)\end{array}$ \\
\hline \multirow[t]{2}{*}{$\begin{array}{l}\text { Manufacturing \# } \\
\text { Broad Offshoring }\end{array}$} & & & $\begin{array}{c}0.08 * * * \\
(0.01)\end{array}$ & $\begin{array}{c}0.19 * * * \\
(0.06)\end{array}$ & & & $\begin{array}{l}-0.01^{*} \\
(0.01)\end{array}$ & $\begin{array}{c}-0.01 \\
(0.01))\end{array}$ \\
\hline & \multicolumn{8}{|c|}{ First Stage } \\
\hline Offshoring Other Countries & & $\begin{array}{c}0.23^{* * *} \\
(0.02)\end{array}$ & & $\begin{array}{c}0.25^{* * *} \\
(0.03)\end{array}$ & & $\begin{array}{c}0.23^{* * *} \\
(0.02)\end{array}$ & & $\begin{array}{c}0.25^{* * *} \\
(0.03)\end{array}$ \\
\hline F test & & 122.06 & & 54.75 & & 122.06 & & 54.75 \\
\hline Control Variables & $\sqrt{ }$ & $\sqrt{ }$ & $\sqrt{ }$ & $\sqrt{ }$ & $\sqrt{ }$ & $\sqrt{ }$ & $\sqrt{ }$ & $\sqrt{ }$ \\
\hline Local Area \# Year & $\sqrt{ }$ & $\sqrt{ }$ & $\sqrt{ }$ & $\sqrt{ }$ & $\sqrt{ }$ & $\sqrt{ }$ & $\sqrt{ }$ & $\sqrt{ }$ \\
\hline Sector \# Year & $\sqrt{ }$ & $\sqrt{ }$ & $\sqrt{ }$ & $\sqrt{ }$ & $\sqrt{ }$ & $\sqrt{ }$ & $\sqrt{ }$ & $\sqrt{ }$ \\
\hline $\mathrm{N}$ & 104,198 & 104,198 & 104,198 & 104,198 & 104,198 & 104,198 & 104,198 & 104,198 \\
\hline
\end{tabular}

Source: ARD/ABS (ONS). Standard errors in parentheses are clustered at the sector and local area level. Dependent variable: Logarithm of Employment, Logarithm of Average Wage, Logarithm of Productivity. The base for the interaction variable is the service industry. Control variables: log of share of British owned firms in a sector local area and the log of expenditure in computer service, lagged 1 year. ${ }^{*}(p<0.10),{ }^{* *}(p<0.05),{ }^{* * *}(p<0.01)$

\section{Extensions to aggregate analysis}

The data used allows to extend the analysis to different types of services and country of origin of the service. The present section shows the results when restricting services offshoring to a narrower definition and when disentangling trade flows by country of origin of the service.

Figure A.1 shows, in descending order, the imported services surveyed in the ITIS in 2012. Intra-firm services are those most traded, accounting for almost $20 \%$ of all imports. According to the definition used in the survey, intra-firm services indicate trade flows across borders within the same company. It is therefore a composite of services not clearly specified that firms declare to trade with their affiliates abroad.

Table D.3 shows a strong positive elasticity for all the outcome variables (employment and average wage) to the offshoring of services between related firms. A $10 \%$ increase in offshoring of intra-firms services corresponds to a $0.6 \%$ increase in employment (table D.3 column 1) and to $0.1 \%$ increase in average wage (column 5). Results are still positive, significant and of stronger magnitude when implementing the instrument for employment, while statistically insignificant for average wages.

The country where a service is offshored might cause different effects on the labour market. Ebestein et al. (2014) show that offshoring of manufacturing towards low-income countries tends to decrease 
Table D.3: Employment and average wage elasticity to intra firm services offshoring

\begin{tabular}{|c|c|c|c|c|c|c|c|c|}
\hline & \multicolumn{4}{|c|}{ Employment } & \multicolumn{4}{|c|}{ Average Wage } \\
\hline & $(1)$ & $(2)$ & $(3)$ & (4) & $(5)$ & (6) & $(7)$ & (8) \\
\hline & OLS & IV & OLS & IV & OLS & IV & OLS & IV \\
\hline Offshoring & $\begin{array}{c}0.06^{* * *} \\
(0.02)\end{array}$ & $\begin{array}{c}0.44^{* * *} \\
(0.16)\end{array}$ & $\begin{array}{l}0.04^{* *} \\
(0.02)\end{array}$ & $\begin{array}{l}0.38^{*} \\
(0.20)\end{array}$ & $\begin{array}{c}0.01 \\
(0.01)\end{array}$ & $\begin{array}{l}-0.03 \\
(0.08)\end{array}$ & $\begin{array}{c}0.03^{* * *} \\
(0.01)\end{array}$ & $\begin{array}{c}0.07 \\
(0.08)\end{array}$ \\
\hline $\begin{array}{l}\text { Manufacturing \# } \\
\text { Offshoring }\end{array}$ & & & $\begin{array}{l}0.06^{* *} \\
(0.03)\end{array}$ & $\begin{array}{c}0.12 \\
(0.32)\end{array}$ & & & $\begin{array}{c}-0.04^{* *} \\
(0.02)\end{array}$ & $\begin{array}{l}-0.25 \\
(0.20)\end{array}$ \\
\hline
\end{tabular}

\begin{tabular}{lcccccccc}
\hline Control Variables & $\sqrt{ }$ & $\sqrt{ }$ & $\sqrt{ }$ & $\sqrt{ }$ & $\sqrt{ }$ & $\sqrt{ }$ & $\sqrt{ }$ & $\sqrt{ }$ \\
LocArea\#Year & $\sqrt{ }$ & $\sqrt{ }$ & $\sqrt{ }$ & $\sqrt{ }$ & $\sqrt{ }$ & $\sqrt{ }$ & $\sqrt{ }$ & $\sqrt{ }$ \\
Sector\#Year & $\sqrt{ }$ & $\sqrt{ }$ & $\sqrt{ }$ & $\sqrt{ }$ & $\sqrt{ }$ & $\sqrt{ }$ & $\sqrt{ }$ & $\sqrt{ }$ \\
$\mathrm{N}$ & 573 & 573 & 573 & 573 & 573 & 573 & 573 & 573 \\
\hline \hline
\end{tabular}

Source: Data obtained combining ARD/ABS, ITIS datasets (ONS). Standard errors in parentheses are clustered at the sector and local area level. Dependent variable: Logarithm of Employment (Columns 1-4), Logarithm of Average Wage (Columns 5-8). Control variables: log of share of British owned firms in a sector local area and the log of expenditure in computer service, lagged 1 year. Local ligit sector specification. The sample of analysis used in the table is line markets with positive services offshoring. ${ }^{*}(p<0.10),{ }^{* *}(p<0.05),{ }^{* * *}(p<0.01)$

wages and employment in routine occupations, while the effects are non-significant when offshoring towards high-income countries. I therefore analyse the effects of services offshoring depending on the country of origin of services. As shown in figure A.2, the main countries British firms are importing from are the US, accounting for $23.73 \%$ of total imports in 2012, followed by a set of other EU countries (Germany, Italy, Ireland, France, Sweden and the Netherlands). Other relevant countries for British imports of services are Japan (3.62\% of the total), Switzerland (2.88\%), India (2.88\%) and China (less than $1 \%$ of the total).

The analysis is then divided between imports from the US, some EU countries (Germany, France, Italy and Ireland), India and China. I exclude Switzerland as the flows of services between the two countries are mainly of financial services, for which an incomplete picture is contained in the data available. A 10\% rise in services offshoring to the US and EU corresponds an increase of - respectively$8.2 \%$ and $9.9 \%$ in employment. For services from US and EU, a $10 \%$ increase in offshoring leads to an increase of $0.6 \%$ (for the US) $0.7 \%$ (for EU) in average wages. The differences in the elasticities of employment and average wages between the US and the EU is not statistically significant. At the same time, the elasticity of employment and average wages to services offshoring to India and China (figure D.1) is not significantly different from zero.

Therefore, and differently from the manufacturing offshoring, services offshoring towards low-income countries has negligible effects on local employment and average wage. The latter result is consistent with what observed by Liu and Trefler (2019) estimating the impact on the labour force of services imports from China and India in the US. Simultaneously, and similar to the manufacturing offshoring, services offshoring towards high-income countries as the US and EU has positive impacts on employment and average wages. These results might be driven by the type of service offshored in each 
countries, a fruitful topic I leave for future research.

Figure D.1: Elasticity of employment and average wage to services offshoring by country of origin of services

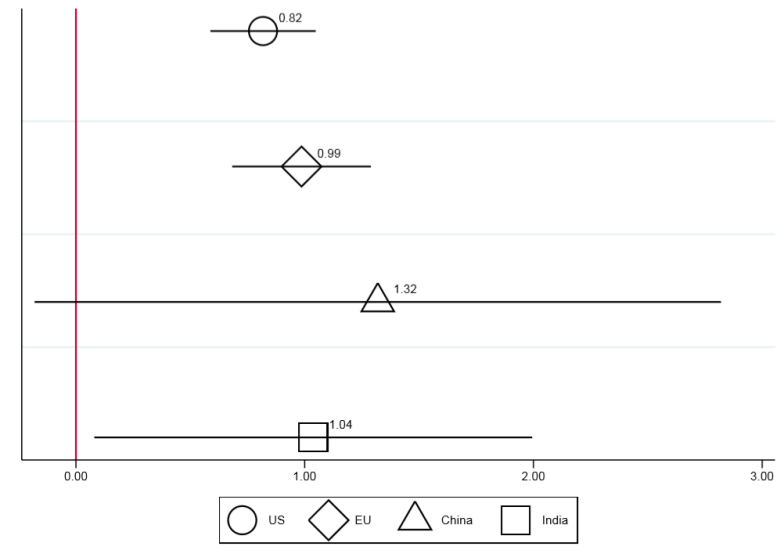

(a) Employment Elasticity

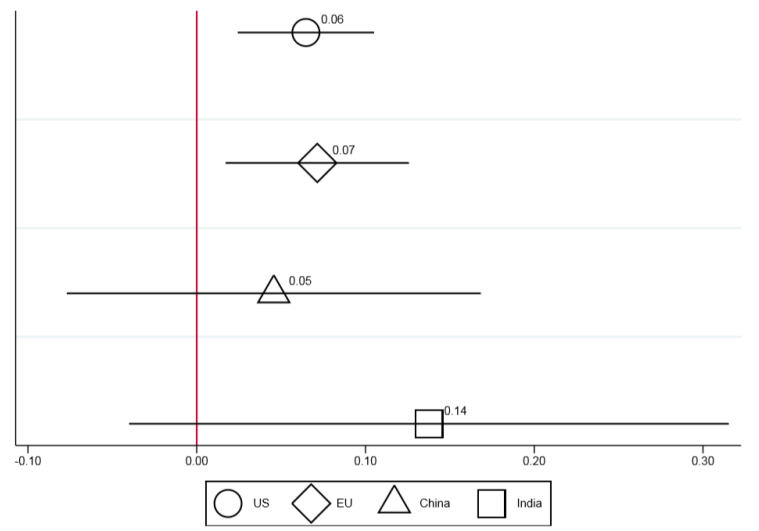

(b) Average Wage Elasticity

Source: Data obtained combining ARD/ABS, ITIS datasets (ONS). Second stage regression coefficients by country of origin. Each regression contains sector-year, local area-year fixed effects. 